Prepared in cooperation with the Nebraska Game and Parks Commission

\title{
Geomorphic Segmentation, Hydraulic Geometry, and Hydraulic Microhabitats of the Niobrara River, Nebraska- Methods and Initial Results
}

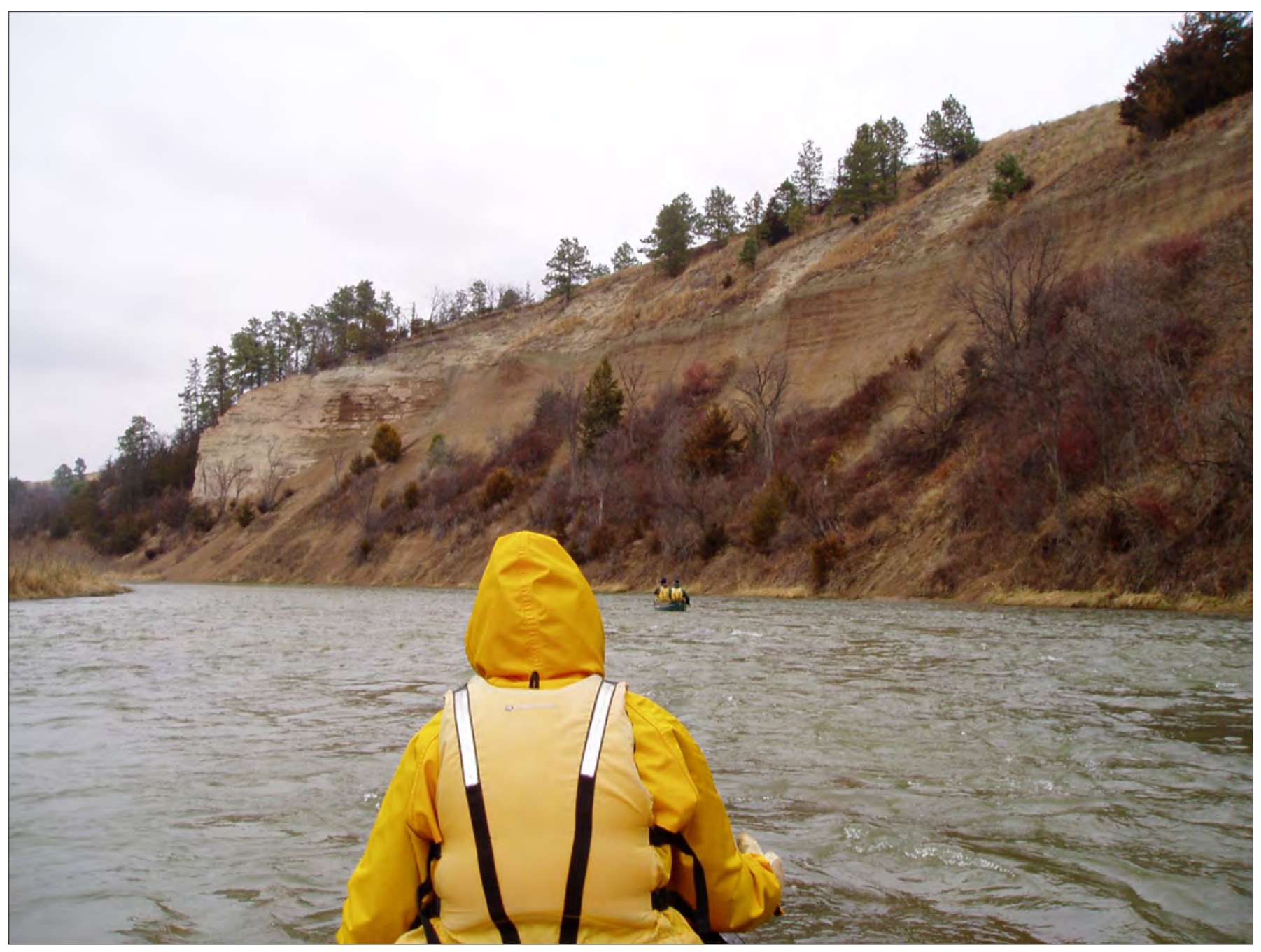

Scientific Investigations Report 2009-5008 
Front cover. Canoeists paddling the Niobrara River in the Niobrara National Wildlife Refuge, Nebraska, April 9, 2008. (photograph taken by Jason Alexander, USGS) 


\section{Geomorphic Segmentation, Hydraulic Geometry, and Hydraulic Microhabitats of the Niobrara River, Nebraska-Methods and Initial Results}

By Jason S. Alexander, Ronald B. Zelt, and Nathaniel J. Schaepe

Prepared in cooperation with the Nebraska Game and Parks Commission

Scientific Investigations Report 2009-5008 


\title{
U.S. Department of the Interior \\ KEN SALAZAR, Secretary
}

\author{
U.S. Geological Survey \\ Suzette M. Kimball, Acting Director
}

U.S. Geological Survey, Reston, Virginia: 2009

For more information on the USGS - the Federal source for science about the Earth, its natural and living resources, natural hazards, and the environment, visit http://www.usgs.gov or call 1-888-ASK-USGS

For an overview of USGS information products, including maps, imagery, and publications, visit http://www.usgs.gov/pubprod

To order this and other USGS information products, visit http://store.usgs.gov

Any use of trade, product, or firm names is for descriptive purposes only and does not imply endorsement by the U.S. Government.

Although this report is in the public domain, permission must be secured from the individual copyright owners to reproduce any copyrighted materials contained within this report.

Suggested citation:

Alexander, J.S., Zelt, R.B., and Schaepe, N.J., 2009, Geomorphic segmentation, hydraulic geometry, and hydraulic microhabitats of the Niobrara River, Nebraska-Methods and initial results: U.S. Geological Survey Scientific Investigations Report 2009-5008, 51 p. 


\section{Contents}

Abstract

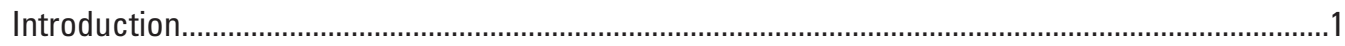

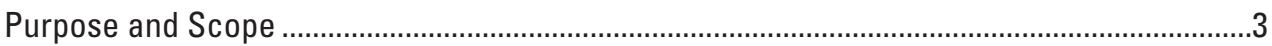

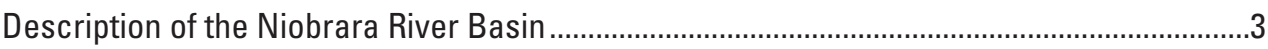

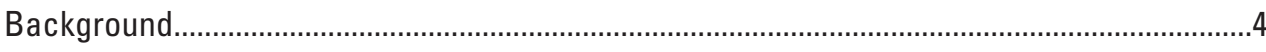

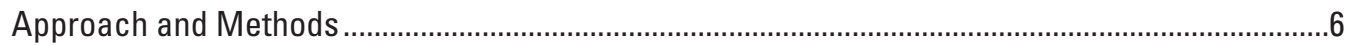

Inventory and Compilation of Available Data ............................................................................

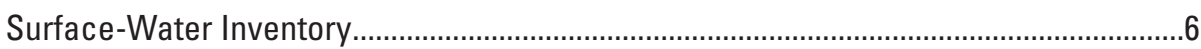

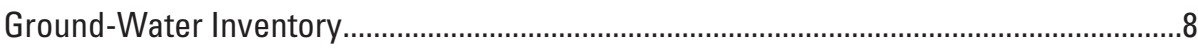

Geomorphic Segmentation of the Niobrara River ................................................................

Classification Scheme for Longitudinal Segmentation ..................................................

Longitudinal Profile Analysis ....................................................................................

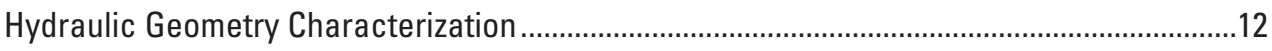

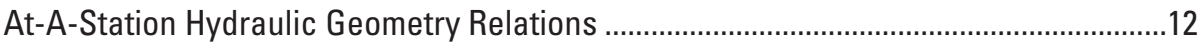

Downstream Hydraulic Geometry Relations ................................................................14

Hydraulic Habitat at a Streamflow-Gaging Station............................................................14

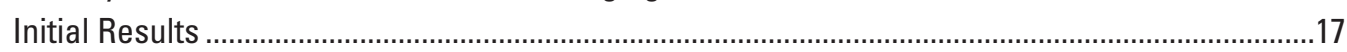

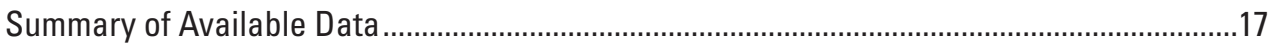

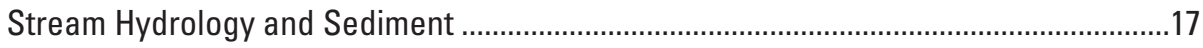

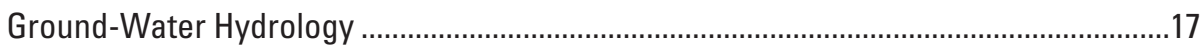

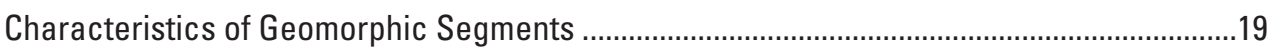

Longitudinal Segmentation .................................................................................19

Longitudinal Profile Characteristics of the Niobrara River..............................................20

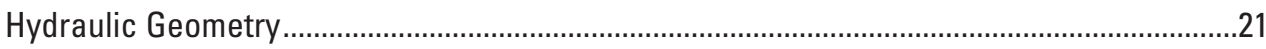

At-A-Station Hydraulic Geometry Relations for Selected Niobrara River Streamflow-

Gaging Stations ....................................................................................................21

Downstream Hydraulic Geometry of Niobrara River .......................................................25

Hydraulic Microhabitat: An Example from the Niobrara River near Sparks, Nebraska .........29

Summary and Conclusions.........................................................................................................

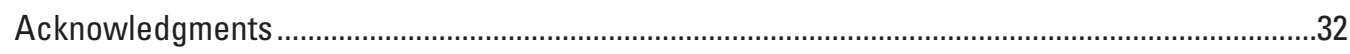

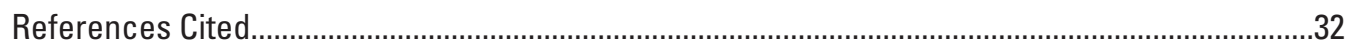

Appendix 1: Description of Niobrara River Streamflow-Gaging Stations ......................................36

Appendix 1 Summary........................................................................................................

Niobrara River near Hay Springs ................................................................................36

Niobrara River near Gordon........................................................................................

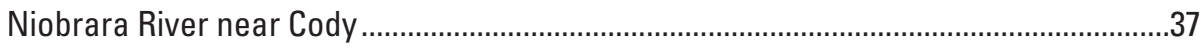

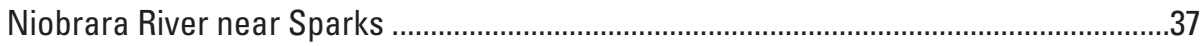

Niobrara River near Norden ....................................................................................

Niobrara River at Mariaville...............................................................................................38

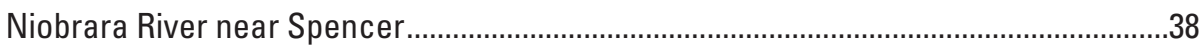

Niobrara River near Verdel .................................................................................. 40

Appendix 2: Scatter Plots of At-A-Station Hydraulic Geometry Relations........................................43

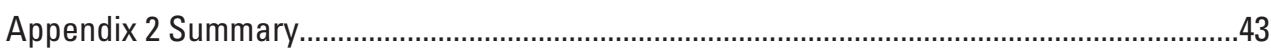




\section{Figures}

1-2. Maps showing:

1. Study area, basin boundary, and National River reaches of the Niobrara River...............2

2. Dams, surface-water diversions, and large tributary drainages within the Niobrara River Basin.

3. Example of cross-section layout and subsections for point measurements used to calculate discharge and channel hydraulic geometry for a typical river streamflow-gaging station....

4. Map showing streamflow-gaging stations in the Niobrara River Basin selected for data inventory.

5. Graph showing flow-duration curves for selected streamflow gages and periods of record of the Niobrara River between Dunlap Diversion Dam and the Missouri River, Nebraska

6-7. Maps showing:

6. Ground-water well density in the Niobrara River study area

7. Ground-water observation wells and geologic test holes in the Niobrara River study area.

8-11. Graphs showing:

8. Longitudinal profile of the Niobrara River from the Missouri River upstream to Dunlap Diversion Dam.

9. At-a-station hydraulic geometry relations for selected streamflow-gaging stations on the Niobrara River

10. Downstream hydraulic geometry relations for the Niobrara River between the streamflow-gaging station near Hay Springs, Nebraska, and the streamflow-gaging station near Verdel, Nebraska.

11. Channel geometry, velocity distribution, and microhabitat extent over a range of flow-exceedance frequencies for the Niobrara River near Sparks, Nebraska.

\section{Tables}

1. Data categories and scopes for Niobrara River data inventory and summary

2. Niobrara River tributaries and their percentage of contributing basin drainage area at their confluence with the main channel.

3. Segment-scale geomorphic classification system for the Niobrara River, Nebraska....11

4. Flow-exceedance frequencies and associated discharges used for downstream hydraulic-geometry calculations

5. Matrix of depth and velocity combinations used to define hydraulic-habitat niches for microhabitat analysis using streamflow measurement data.

6. Discharge measurements and associated flow frequencies at Niobrara River near

Sparks, Nebraska, used in hydraulic-microhabitat calculations

7. Active and inactive streamflow-gaging stations of the Niobrara River Basin study area

8. Inventory of hydrographer's discharge measurement notes at Niobrara River Basin gaging stations with records after 1963. 
9. Inventory of ground-water wells and test holes in the Niobrara River study area by state and usage type.

10. Geomorphic segments of the Niobrara River between Dunlap Diversion Dam and the Missouri River, Nebraska...

11. Summary of longitudinal channel slopes in fluvial geomorphic provinces of the Niobrara River, Nebraska

12. At-a-station hydraulic geometry relations for selected Niobrara River streamflowgaging stations.

13. Downstream hydraulic geometry relations for the Niobrara River between Hay Springs and Verdel, Nebraska.

\section{Appendix Figures}

1-1-1-7. Photographs showing:

1-1. The Niobrara River near Gordon streamflow-gaging station reach ...............................36

1-2. The Niobrara River near Cody streamflow-gaging station reach ...................................37

1-3. The Niobrara River near Sparks streamflow-gaging station reach................................... 38

1-4. The Niobrara River near Norden streamflow-gaging station reach ............................... 39

1-5. The Niobrara River near Mariaville streamflow-gaging station reach ...........................40

1-6. The Niobrara River near Spencer streamflow-gaging station reach ............................ 41

1-7. The Niobrara River near Verdel streamflow-gaging station reach....................................42

2-1-2-9. Scatter plots showing:

2-1. The at-a-station hydraulic geometry relations for the USGS streamflow-gaging station on the Niobrara River near Hay Springs, Nebraska (06456500).

2-2. The at-a-station hydraulic geometry relations for the USGS streamflow-gaging station on the Niobrara River near Gordon, Nebraska (06457500)

2-3. The at-a-station hydraulic geometry relations for the USGS streamflow-gaging station on the Niobrara River near Cody, Nebraska (06459000).

2-4. The at-a-station hydraulic geometry relations for the USGS streamflow-gaging station on the Niobrara River near Sparks, Nebraska (06461500)

2-5. The at-a-station hydraulic geometry relations for the USGS streamflow-gaging station on the Niobrara River near Norden, Nebraska (06462000).

2-6. The at-a-station hydraulic geometry relations for the USGS streamflow-gaging station on the Niobrara River near Mariaville, Nebraska (06463720)

2-7. The at-a-station hydraulic geometry relations for the USGS streamflow-gaging station on the Niobrara River near Spencer, Nebraska (06465000)

2-8. The at-a-station hydraulic geometry relations for the USGS streamflow-gaging station on the Niobrara River near Verdel, Nebraska (06465500) for water years 1964 to 1985

2-9. The at-a-station hydraulic geometry relations for the USGS streamflow-gaging station on the Niobrara River near Verdel, Nebraska (06465500) for water years 1986 to 2007. 


\section{Conversion Factors}

\begin{tabular}{lcl}
\hline \multicolumn{1}{c}{ Multiply } & By & \multicolumn{1}{c}{ To obtain } \\
\hline inch (in.) & Length & \\
foot (ft) & 2.54 & centimeter $(\mathrm{cm})$ \\
mile (mi) & 0.3048 & meter $(\mathrm{m})$ \\
& 1.609 & kilometer $(\mathrm{km})$ \\
\hline square mile $\left(\mathrm{mi}^{2}\right)$ & Area & \\
\hline & 259.0 & hectare $(\mathrm{ha})$ \\
\hline quart (qt) & Volume & liter $(\mathrm{L})$ \\
gallon (gal) & 0.9464 & liter $(\mathrm{L})$ \\
million gallons $(\mathrm{Mgal})$ & 3.785 & cubic meter $\left(\mathrm{m}^{3}\right)$ \\
acre-foot (acre-ft) & 3,785 & cubic meter $\left(\mathrm{m}^{3}\right)$ \\
\hline & 1,233 & \\
\hline acre-foot per day (acre-ft/d) & Flow rate & cubic meter per second $\left(\mathrm{m}^{3} / \mathrm{s}\right)$ \\
foot per second (ft/s) & 0.01427 & meter per second $(\mathrm{m} / \mathrm{s})$ \\
cubic foot per second $(\mathrm{ft} 3 / \mathrm{s})$ & 0.3048 & cubic meter per second $\left(\mathrm{m}^{3} / \mathrm{s}\right)$ \\
\hline
\end{tabular}

Vertical coordinate information is referenced to the North American Vertical Datum of 1988 (NAVD 88).

Horizontal coordinate information is referenced to the North American Datum of 1983 (NAD 83). 


\title{
Geomorphic Segmentation, Hydraulic Geometry, and Hydraulic Microhabitats of the Niobrara River, Nebraska-Methods and Initial Results
}

\author{
By Jason S. Alexander, Ronald B. Zelt, and Nathaniel J. Schaepe
}

\section{Abstract}

The Niobrara River of Nebraska is a geologically, ecologically, and economically significant resource. The State of Nebraska has recognized the need to better manage the surface- and ground-water resources of the Niobrara River so they are sustainable in the long term. In cooperation with the Nebraska Game and Parks Commission, the U.S. Geological Survey is investigating the hydrogeomorphic settings and hydraulic geometry of the Niobrara River to assist in characterizing the types of broad-scale physical habitat attributes that may be of importance to the ecological resources of the river system. This report includes an inventory of surface-water and ground-water hydrology data, surface water-quality data, a longitudinal geomorphic segmentation and characterization of the main channel and its valley, and hydraulic geometry relations for the 330-mile section of the Niobrara River from Dunlap Diversion Dam in western Nebraska to the Missouri River confluence. Hydraulic microhabitats also were analyzed using available data from discharge measurements to demonstrate the potential application of these data and analysis methods.

The main channel of the Niobrara was partitioned into three distinct fluvial geomorphic provinces: an upper province characterized by open valleys and a sinuous, equiwidth channel; a central province characterized by mixed valley and channel settings, including several entrenched canyon reaches; and a lower province where the valley is wide, yet restricted, but the river also is wide and persistently braided. Within the three fluvial geomorphic provinces, 36 geomorphic segments were identified using a customized, process-orientated classification scheme, which described the basic physical characteristics of the Niobrara River and its valley. Analysis of the longitudinal slope characteristics indicated that the Niobrara River longitudinal profile may be largely bedrock-controlled, with slope inflections co-located at changes in bedrock type at river level. Hydraulic geometry relations indicated that local (at-a-station) channel adjustments of the Niobrara River to changing discharge are accommodated mainly by changes in velocity, and streamwise adjustments are accommodated through changes in channel width. Downstream hydraulic geometry relations are in general agreement with values previously published for rivers of the Great Plains, but coefficients are likely skewed low because the locations of the streamflowgaging stations used in this analysis are located at natural or engineered constrictions and may not be accurately representing downstream adjustment processes of the Niobrara River. A demonstration analysis of hydraulic microhabitat attributes at a single station indicated that changes in velocity-related habitat types is the primary microhabitat adjustment over a range of discharges, but the magnitude of that adjustment for any particular discharge is temporally variable.

\section{Introduction}

On the Great Plains of the central United States, groundand surface-water resources are the foundation of the agriculture-based economies. These same water resources provide the foundation of the aquatic food chain that sustains the fisheries of the Missouri River ecosystem and the wading birds and waterfowl of the central flyway of North America. The juxtaposition of economic interests and natural resources requires an accurate understanding of water resources so they can be managed to sustain both.

The Niobrara River of Nebraska (Nebr.) is known in the Great Plains region as an 'ecologic crossroads' where five major terrestrial ecosystem types converge, creating a locally diverse array of flora and fauna (Johnsgard, 2001). The 76-mile (mi) reach of the river east of Valentine, Nebraska, also called the "scenic reach," is registered and protected within the National Wild and Scenic River System and is renowned for its scenic canyons, abundant waterfalls, and superb canoeing opportunities (fig. 1). Although the scenic reach is the most renowned, it constitutes only about 14 percent of the total river length. The reaches upstream from the scenic reach are less well known but contain a diverse array of fluvial environments that have largely gone unstudied.

The lush beauty of the Niobrara bottomland in the scenic reach has given the river a reputation as a relatively undisturbed ecosystem; however, the present body of data and 


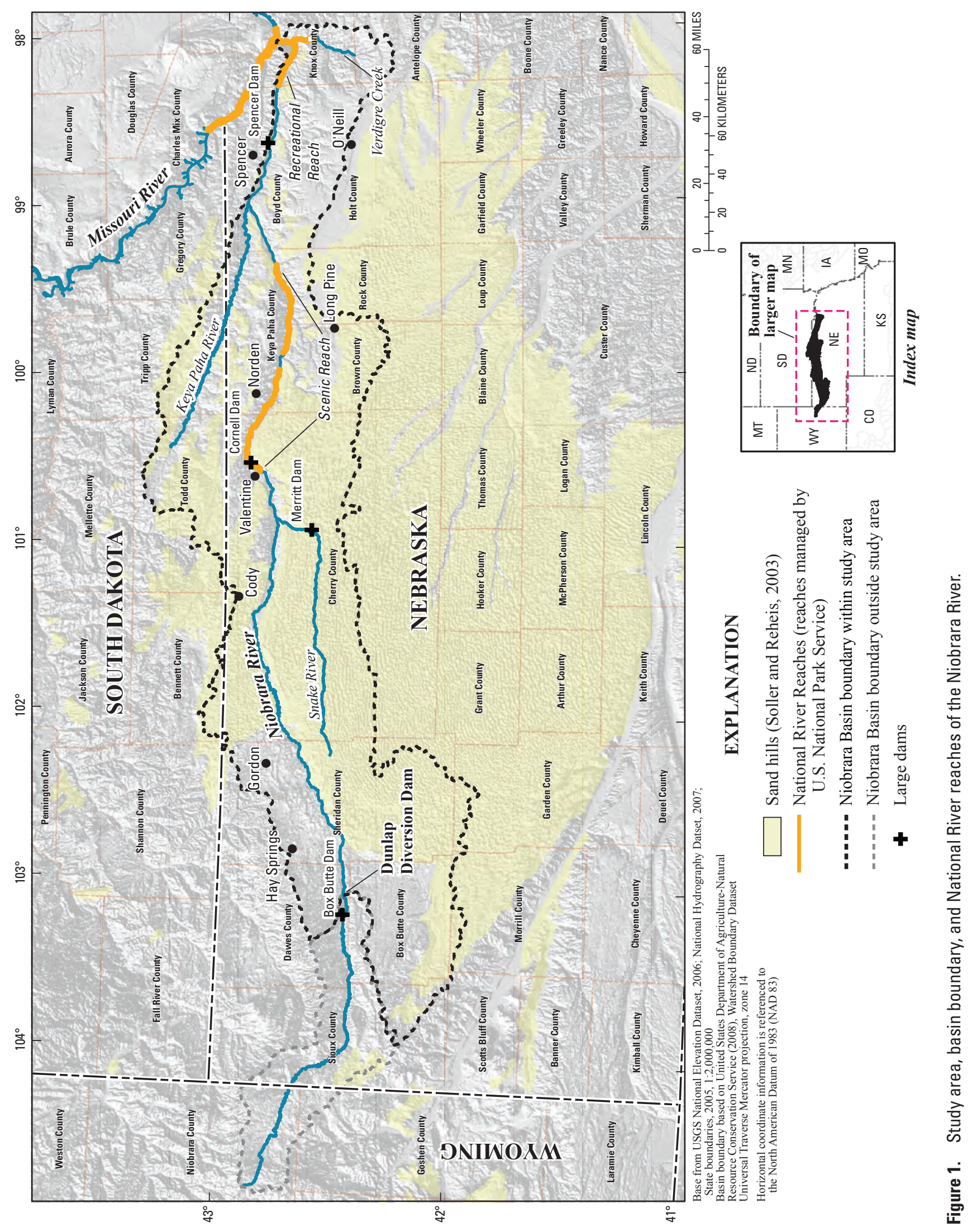


information is inadequate to document the actual condition of the riverine ecosystem today. The persistence of below-average annual and peak flows since 2002, and the recent designation of the hydraulically connected ground- and surface-water resources of most of the Niobrara Basin as "fully appropriated" (Nebraska Department of Natural Resources, 2007), have emphasized the importance of understanding and sustainably managing the flow regime in the Niobrara River.

The U.S. Geological Survey (USGS), in cooperation with the Nebraska Game and Parks Commission (NGPC), is working to characterize the hydrogeomorphic settings and associated processes of the Niobrara River system from the Dunlap Diversion Dam in Dawes County to the confluence with the Missouri River in Knox County more than 330 mi downstream (fig. 1). Among the key questions identified for the study are:

1. What flow regime is needed to maintain the present quantity and diversity of stream physical habitats that distinguish the Niobrara as a healthy ecosystem?

2. What frequency, duration, and timing of infrequent hydrologic disturbances (floods, droughts, ice jams) is needed to maintain a dynamic equilibrium of fluvial geomorphic processes to sustain the present channel character?

An abundance of hydrologic, hydraulic, and sediment data for the Niobrara River has been recorded at different intervals by various federal and state agencies. These data, however, have not been compiled and synthesized for the purpose of addressing the questions stated above. Given the scale of the study area, and the spatial and temporal complexity of river systems in general, an initial attempt at characterizing the hydraulic and geomorphic elements of the Niobrara River must be appropriately broad, yet encompass enough physical detail to build an informational foundation for future, more detailed investigations.

\section{Purpose and Scope}

The purpose of this report is to document the methods for, and present the initial results from, a data inventory and hydrogeomorphic characterization of the Niobrara River of Nebraska and selected tributaries for the approximately 330-mi reach from Dunlap Diversion Dam to its confluence with the Missouri River (fig. 1). The inventory performed was more detailed than that necessary for the data analysis and includes existing hydrologic, hydraulic, geologic, and sediment data for the basin. The goal of the inventory was to identify the types and spatial distribution of available data that could be used in future geomorphic, hydrologic, and hydrogeologic investigations. An analysis of the Niobrara River channel morphology using the longitudinal profile of the river and a process-orientated classification scheme to segment the river is presented. The purpose of the segmentation is to characterize the types and extents of river channel and valley settings within the Niobrara River Basin. The principles of hydraulic geometry are applied at several streamflow-gaging stations of the Niobrara River to describe the hydraulic adjustment mechanisms at the local and basin scales. In addition, an example application of the relation between streamflow variability and hydraulic microhabitats at a streamflow-gaging station using a semi-automated method is demonstrated.

\section{Description of the Niobrara River Basin}

The Niobrara River Basin is a component of the Greater Missouri River Basin and originates in the tablelands of northeastern Wyoming (University of Nebraska-Lincoln, Conservation and Survey Division, 1986). The Niobrara River begins at an altitude of approximately 5,500 feet (ft) and flows eastward nearly $560 \mathrm{mi}$ through Wyoming and northern Nebraska, dropping 4,280 ft before its confluence with the Missouri River in Knox County, Nebr. Draining a total area of approximately 13,480 square miles $\left(\mathrm{mi}^{2}\right)$ along its course, the Niobrara River flows alternately through open valleys, valleys bound by escarpments, and narrow canyons. Average annual precipitation in the basin varies from approximately 16 inches (in.) in the west to $24 \mathrm{in}$. in the east. The northernmost extent of the basin drains the tablelands of South Dakota (University of Nebraska-Lincoln, Conservation and Survey Division, 1986). Much of the southern part of the river basin is in the Nebraska Sand Hills, whose underlying aquifers contribute a steady flow of ground water to the river and its tributaries (Bentall and Shaffer, 1979). The effects of flashier, rainfall-runoff hydrology steadily increase east of Norden, Nebr., resulting from changes in soil types, reductions in aquifer thickness, and increases in average annual precipitation (Bentall, 1991). On average, the Niobrara River contributes 1.2 million acre-feet (acre-ft) of water to the Missouri River annually (Bentall and Schaffer, 1979). Much of the land of the Niobrara River Basin is undeveloped. Cattle ranching is the dominant land use in the more arid western region and gives way to row-crop agriculture in the eastern region (Dappen and others, 2007).

Sedimentary rock units along the Niobrara River in Nebraska range in age from the Cretaceous to Tertiary periods. Bedrock units in the Niobrara River Basin are gently sloping to flat lying, except in Sheridan and western Cherry Counties, where the Niobrara River Basin crosses the Chadron Arch, an area of local compression and uplift of Cretaceous-age rocks (Hearty, 1978). Cretaceous-age Niobrara Chalk underlies the Niobrara River from the mouth to approximately 10 mi upstream. Where present, the Niobrara Chalk forms the nearly vertical bluffs of the valley wall. Between the upstream extent of Niobrara Chalk and Norden, Nebr., the dominant rock at river level is the Cretaceous-age Pierre Shale, which is a mix of black mudstones, shales, and chalks (Condra and Reed, 1943). The overlying Tertiary-age sedimentary units are broadly divided into three groups: White River Group, Arikaree Group, and Ogallala Group. Each of these rock groups include several formations within them. The details of the lithologies of each formation are spatially complex and outside of the scope of this document. Formations of the White River 
Group generally consist of easily eroded fine silt and clay, with occasional resistant gravel and sand that form ledges and steep slopes. The Arikaree Group consists of siltstone, tuffaceous siltstone, and clay units, many of which are ash layers deposited by wind and/or water. The Ogallala Group is spatially complex, but in general consists of sand and gravel, with occasional ash beds. The Ash Hollow Formation is the uppermost unit of the Ogallala Group and is well-cemented beds of silt, sand, and gravel, forming the resistant capstone of the Niobrara canyon in the scenic reach. (Condra and Reed, 1943; Hearty, 1978).

The Niobrara River in the scenic reach purveys the appearance of a wild river; however, the river basin has many engineered structures and streamflow diversions (fig. 2). Along the main channel, Box Butte Reservoir at Box Butte Dam (fig. 1), in Dawes County, Nebr., began storing water for irrigation as part of the Mirage Flats Project in 1945 (Shaffer, 1975). Water is released from the dam and diverted at Dunlap Diversion Dam 8 mi downstream. Immediately below Dunlap Diversion Dam (fig. 1), average annual streamflow in the main channel is reduced by up to 90 percent relative to upstream from Box Butte Reservoir (Shaffer, 1975). Merritt Dam, on the Snake River, which is the third largest tributary to the Niobrara by drainage area, began operations in 1964 as part of the Ainsworth Irrigation Project. Merritt Reservoir at Merritt Dam (fig. 1) can store up to one-half of the total annual discharge of the Snake River. Operations at Merritt Reservoir have affected the high-frequency (low-magnitude) flows, reducing base flows (flows generally exceeded 99 percent of the time) by more than 90 percent in the Snake River (Shaffer, 1975).

Merritt Reservoir operations also have affected streamflows on the Niobrara River below the Snake River confluence, reducing mean monthly flows at Norden, Nebr., by up to 15 percent (Buchanan, 1981). In addition to water-storage dams, there are two dams on the Niobrara main channel that were constructed for power generation. Cornell Dam (fig. 1), located east of Valentine, Nebr., was built in 1915, and remained an active hydropower site until 1985. Spencer Dam (fig. 1), located south of Spencer, Nebr., was built in 1927 by the Nebraska Public Power and Irrigation District and currently (2008) is active. Both dams act as sediment barriers, although the reservoir behind Cornell Dam has filled completely with sediment since the ceasing of hydropower operations, and likely much of the upstream sediment supply passes through.

The Niobrara River flows mainly through private property, although several miles of river are owned and managed by state and federal natural resources agencies, and others by private land trusts. Two sections of the river are federally protected under the Wild and Scenic Rivers Act of 1968 (Interagency Wild and Scenic Rivers Council, 2008), and cooperatively managed with private landholders and State entities by the U.S. Department of the Interior, National Park Service: the 76-mile reach designated as "scenic" beginning a few miles upstream from Cornell Dam, near Valentine, Nebr., and ending in Rock County, Nebr.; and the 28-mi reach designated as "recreational" between the western border of Knox County,
Nebr., and the Missouri River (fig. 1). The 76-mi scenic reach has more than 40,000 tourists per year, who come to float the river and enjoy the beauty of the Niobrara Valley (Whittaker and Shelby, 2008).

\section{Background}

Alterations in the natural flow regime of any river or stream can result in adjustments to the overall planform (geometry), cross-sectional channel geometry, bed configuration, and channel-bed slope (Leopold and Wolman 1957; Brice and Blodgett, 1978; Williams and Wolman, 1984; Knighton, 1998). These changes in the hydrogeomorphic attributes of a river channel may cascade into degradation of its physical habitat attributes, which are important for aquatic and riparian life (Poff and Ward, 1990; Power and others, 1995; Hupp and Osterkamp, 1996; Poff and others, 1997). The term 'hydrogeomorphic' is used in this report to encompass the host of form characteristics and processes associated with the interactions of water (hydro) and the landscape through which it flows (geomorphic).

One of the existing management approaches for the conservation of river ecosystems is the determination of the hydrologic regime necessary to maintain a dynamic interaction between the physical and biological characteristics of a river system (Jowett, 1997; Poff and others, 1997). Thus, an integrated study of the hydrology and hydraulics of a river system will recognize and be coupled with a biological analysis using a common set of variables. River discharge, often considered the primary determinant of physical and ecological processes in river systems, is a powerful and accessible choice among a suite of variables commonly used across these disciplines (Resh and others, 1988; Junk and others, 1989; Power and others, 1995; Doyle and others, 2005).

Hydraulic geometry relations use the hydrographer's streamflow discharge-measurement notes from individual streamflow-gaging stations (at-a-station geometry) to relate wetted-channel geometry and water velocity to river discharge through a series of empirical models in the form of power laws as presented by Leopold and Maddock (1953):

$$
\begin{aligned}
& \mathrm{w}=\mathrm{aQ}^{b} \\
& \mathrm{~d}=\mathrm{cQ}^{f} \\
& \mathrm{v}=\mathrm{kQ}^{m}
\end{aligned}
$$

The variables $w, d$, and $v$ are wetted-channel top width, mean depth, and mean velocity of the cross section, respectively; $a, c, k, b, f$, and $m$ are numerical constants; and $Q$ is a reference discharge. The product of $w, d$, and $v$ are equal to $Q$, an equation known to hydrologists as "continuity," because over short distances, the discharge of a river must be the 


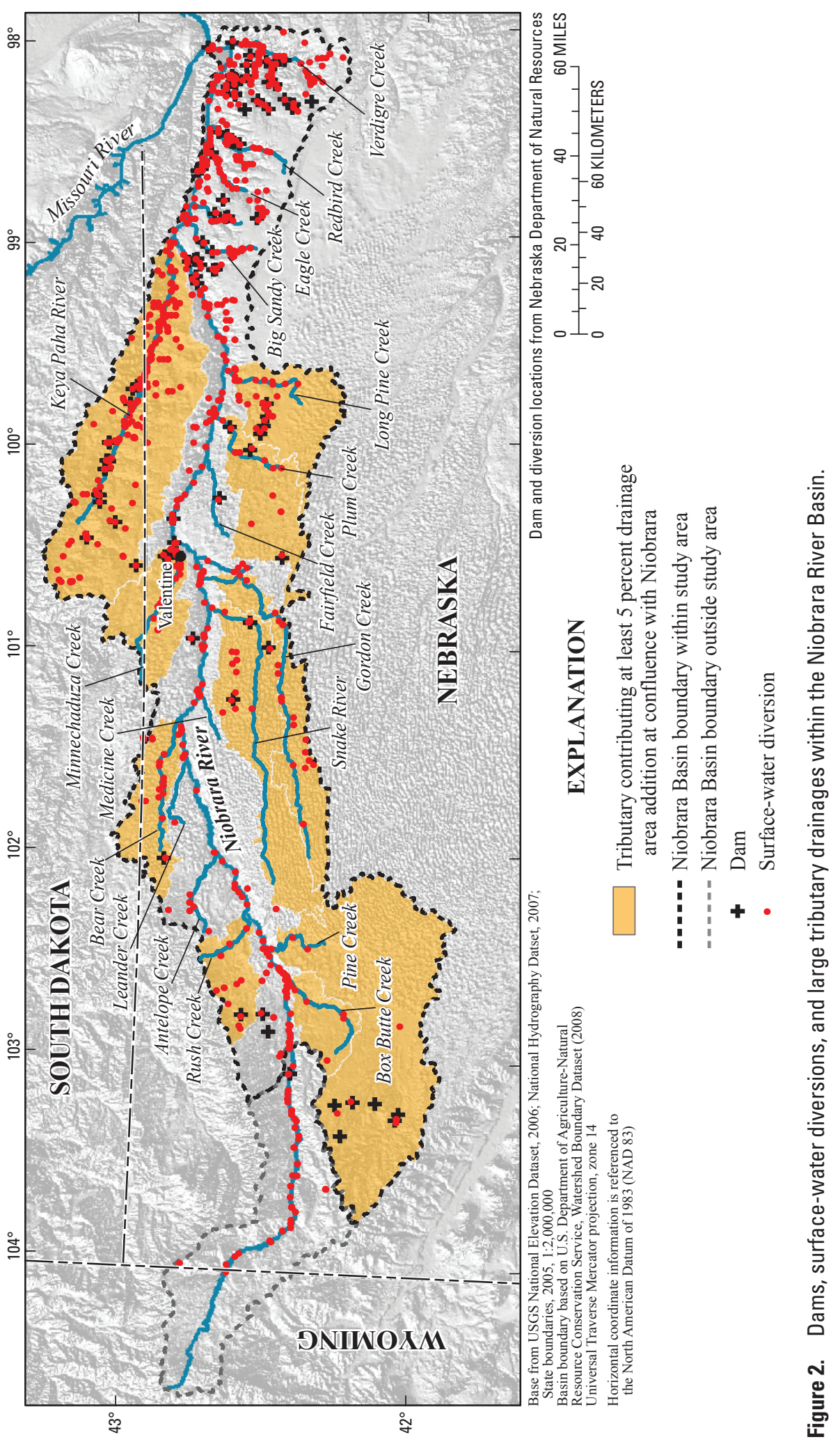


same, even if the geometry of the river changes. By continuity, the exponents of equations 1-3 must sum to unity, and the products of the coefficients of equations $1-3$ must be unity. The magnitude of the exponent for each equation describes the slope of a best-fit (least-squares regression) line through a logarithmically scaled scatter plot of the relation, with discharge as the independent variable. The magnitude of the slope is a measure of the rate of adjustment of each variable at a cross section over a range of discharges. For the United States, rivers of the semi-arid Southwest and Great Plains, Leopold and Maddock (1953) reported averages of 0.26, 0.40, and 0.34 for exponents $b, f$, and $m$, respectively, although these values have been shown to be highly variable depending on regional climate and physiography (Park, 1977).

Hydraulic geometry relations also can be developed for a river basin using data from multiple streamflow-gaging stations, common measurement increments, and common periods of record. Leopold and Maddock (1953) referred to such models as "downstream hydraulic geometry" relations. These relations are examined to understand how a stream channel adjusts and accommodates gains of water and sediment with increases in drainage area. Downstream hydraulic geometry relations use equations 1 to 3 , but the reference discharges used for the independent variable are populated with daily flows of common exceedance frequencies (percentage of time exceeded) for all gages. Although a range of values for the downstream hydraulic geometry coefficients and exponents have been reported, investigators consistently have reported that channel width varies approximately in proportion to the square root of discharge (that is, $b=0.5$ ) for alluvial rivers (Parker, 1979; Parker and others, 2007). Hydraulic geometry relations assist in understanding channel adjustment processes but are limited in their predictive capabilities and require cautious application for such purposes (Simon and Castro, 2003).

In addition to cross-sectional adjustments, the planform and profile (longitudinal slope) characteristics of a river also adjust to changing water and sediment inputs. Although a few studies of the Niobrara River have provided details of the modern river's physical characteristics at the local or reach scale (Hearty, 1978; Buchanan, 1981; Cole, 1996; Skelly, 1998; Etheridge and others, 1999), no consistent descriptive procedure has been applied at the system or basin scale. An objective description of the river at such a scale can provide a benchmark for future comparative studies, and is useful as a means of identifying the locations of particular types of riverine habitats, broad-scale controls on channel form, or specific fluvial geomorphic processes within the basin. Classification schemes, which involve ordering objects into classes based on pre-defined sets of characteristics, are useful as a means of describing the condition or character of a river at a point in time. Numerous classification schemes for fluvial systems have been developed by investigators and applied for a range of purposes. The most useful classification schemes, however, are tailored to meet the specific goals or objectives of the project (Kondolf and Downs, 1996; Juracek and Fitzpatrick, 2003).

\section{Approach and Methods}

Given the spatial scale of this initial study, the approach must be broad yet provide enough detail to serve as a foundation for future, more focused investigations. This approach to initial characterization of the hydraulic and geomorphic attributes of the Niobrara River used existing data. The approach had three main components: inventory and compilation of available hydrogeomorphic data; geomorphic segmentation by stratification and characterization of the Niobrara River and its valley; and hydraulic geometry analysis. Whereas the inventory was intended to provide an informational foundation, the geomorphic stratification and hydraulic geometry analyses sought to characterize the types of valley and channel environments and channel-adjustment processes in the study area. Finally, an example application of the relation between streamflow variability and hydraulic microhabitats using a semi-automated method was conducted.

\section{Inventory and Compilation of Available Data}

An ancillary component of any scientific investigation is an inventory of data available for analysis within the spatial and temporal scopes. Because this initial investigation was intended to provide an informational foundation, an inventory over and above that necessary for the accompanying investigation was performed. The inventory can generally be divided into two categories: surface-water and ground-water hydrology. Included in the inventory are stream discharge, water quality, ground-water elevation, and geologic test-hole data (table 1).

\section{Surface-Water Inventory}

Stream-discharge and water-quality data were compiled for streamflow-gaging stations throughout the study area. These data included hydrographer's discharge-measurement records and sediment-discharge information. Station information was compiled from internal USGS databases, as well as from the Nebraska Department of Natural Resources (NDNR) streamflow-gage database. In the case of stream hydrology, continuous-record stations and crest-stage stations were inventoried. Continuous-record stations are hydrologic gaging stations that continuously record river stage, which is then converted to river discharge by using a statistical rating relation maintained by a hydrologic technician. Creststage gages record only the maximum elevation of the water surface from the most recent high flow, which is then used to calculate an associated river discharge. For sedimentdischarge data inventory, data retrieval was performed within the USGS National Water Information System (NWIS) (http://waterdata.usgs.gov/nwis). The same process was used for water-quality data. Only sediment and water-quality data collected at streamflow-gaging stations were included in the inventory. 
Table 1. Data categories and scopes for Niobrara River data inventory and summary.

[USGS, U.S. Geological Survey; NDNR, Nebraska Department of Natural Resources; NDEQ, Nebraska Department of Environmental Quality; NNRD, Nebraska Natural Resources Districts; SDDENR, South Dakota Department of Environment and Natural Resources; CSD, University of Nebraska, Conservation and Survey Division]

\begin{tabular}{|c|c|c|c|}
\hline Data category & Temporal scope ${ }^{1}$ & Spatial scope & Data sources \\
\hline Stream discharge & 1964-present & $\begin{array}{l}\text { Main channel from Dunlap } \\
\text { Diversion Dam to mouth; } \\
\text { tributaries with } 5 \text { percent or } \\
\text { greater of drainage area at } \\
\text { confluence. }\end{array}$ & USGS, NDNR, NDEQ \\
\hline Water quality & period of record & $\begin{array}{l}\text { Main channel and tributaries } \\
\text { downstream from Dunlap } \\
\text { Diversion Dam to mouth. }\end{array}$ & USGS, NDNR, NDEQ \\
\hline Ground-water elevation & 1964-present & $\begin{array}{l}\text { Niobrara Basin from Dunlap } \\
\text { Diversion Dam diversion to } \\
\text { mouth. }\end{array}$ & $\begin{array}{l}\text { USGS, NDNR, NNRD, } \\
\text { SDDENR }\end{array}$ \\
\hline Geologic test hole & period of record & $\begin{array}{l}\text { Niobrara Basin from Dunlap } \\
\text { Diversion Dam diversion to } \\
\text { mouth. }\end{array}$ & USGS, NDNR, CSD \\
\hline
\end{tabular}

${ }^{1}$ Years refer to water year, which is defined as October 1-September 30 and ending in the calendar year shown.

Continuous-record streamflow-gaging stations provide a valuable record of channel geometry for a gage's period of operation. This record is maintained because the hydraulic relations between river stage (water level) and discharge occasionally must be checked by a technician, and adjusted (shifted) when changes in the channel shape result in subsequent changes in the stage and discharge statistical relation. The relation between stage and discharge is checked when a hydrographer makes a manual measurement of discharge near the streamflow gage. Stream-discharge measurements consist of measuring current velocity at stations along a cross section of the river (fig. 3). The depth of the point velocity measurements at any distance across the cross section is determined in part by water depth, and in part by velocity, and as such requires measurements of depth at each station (Rantz and others, 1982). The authors refer to these records of discharge measurements as the hydrographer's "dischargemeasurement notes."

Discharge-measurement notes for measurements up to the early 1990s typically are stored as hard copies within the archives of local USGS Water Science Centers; thus, the inventory for streamflow gages with records before that time is a manual counting process. Because of the size of the study area, the inventory of discharge-measurement notes was limited to main-channel stations and tributaries that were most likely to exert a significant effect on the hydrologic and geomorphic character of the Niobrara main channel. Under the assumption that drainage area is a proxy for discharge, the spatial scope of the inventory was limited to tributaries whose drainage area constitutes at least 5 percent of the basin area at the confluence (hereinafter referred to as "large" tributaries) (fig. 2). The drainage areas for the Niobrara River and its tributaries were based on the U.S. Department of AgricultureNatural Resources Conservation Service (2008) Watershed
Boundary Dataset. The dataset was used to compile and sum tributary drainage areas, which were compared to the total drainage area of the Niobrara River Basin at the tributary confluence (table 2). Because the scope of this study is limited to characterizing the post-development river, the inventory generally was limited to streamflow-gaging stations that had records after 1963, the first year of operation of Merritt Reservoir, located on the Snake River, a large tributary. Some main channel streamflow-gaging station records that were critical to the analysis had records limited to periods before 1963 . These records only were used for streamflow-gaging stations upstream from the Snake River confluence. Some of the tributaries had multiple streamflow-gaging stations that fit the selection criteria. In those cases the most downstream stations were selected for inventory. The inventory was expanded to include Eagle, Redbird, and Verdigre Creeks which, although they did not meet our drainage-area criterion, were recognized as ecologically important by project cooperators.

Once the stations were selected, individual dischargemeasurement notes were counted manually and inventoried according to water year. Measurement summaries, including channel discharge, top width, average velocity, and hydraulic control, from stations along the main channel of the Niobrara were entered into the USGS NWIS database (http://waterdata.usgs.gov/nwis). In addition to measurements from continuous-record stations, measurement notes also were available for sites monitored by the Nebraska Department of Environmental Quality (NDEQ). Three NDEQ stations fit some of our selection criteria. One of these sites (Pine Creek near Rushville, Nebr.) was not co-located with a former continuous-streamflow-gaging station; the site was included in the discharge-measurement notes inventory but not in the inventory of streamflow-gaging stations. Discharge measurements by NDEQ also were available from two other 


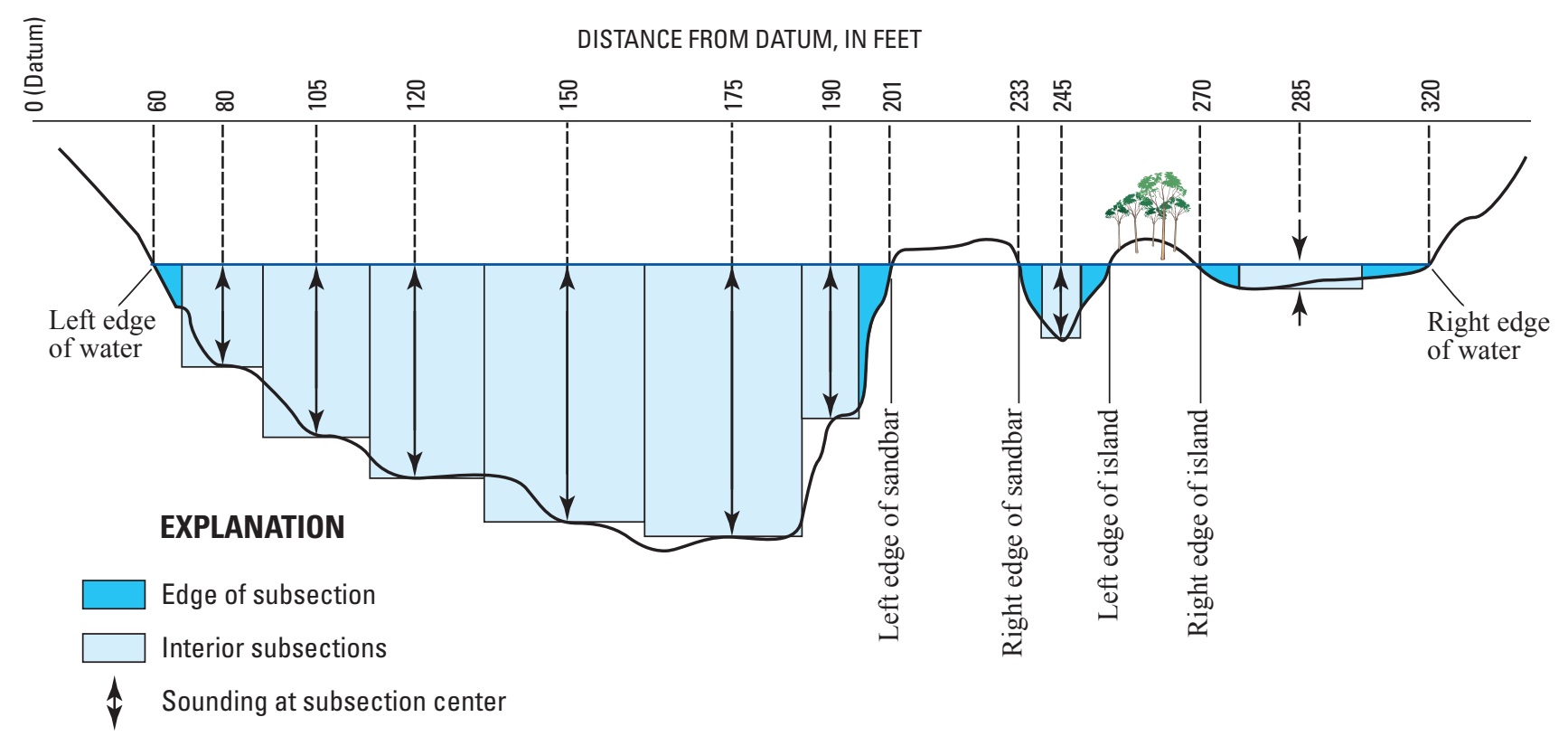

Figure 3. Example of cross-section layout and subsections for point measurements used to calculate discharge and channel hydraulic geometry for a typical river streamflow-gaging station (adapted from Ginting and Zelt, 2008).

directly contributing streams; however, these streams did not fit the drainage-area criterion and thus were not included in the inventory.

\section{Ground-Water Inventory}

For much of its length, the Niobrara River is a groundwater fed stream, with a steady discharge originating in the aquifers underlying the Nebraska Sand Hills (Bentall and Shaffer, 1979). Local streamflow gains and losses can result from stream-aquifer interactions, which may be dictated by the topography of local bedrock, ground-water pumping, and streambed substrate. Gains and losses of surface water in exchange with a shallow aquifer can result from or affect perturbations in channel form, and act as a nutrient source for aquatic organisms (Triska and others, 1993; Baxter and Hauer, 2000).

Geospatial databases of existing ground-water wells and geologic test holes were retrieved and inventoried for the entire study area from existing databases maintained by federal, state, and local entities including the USGS, NDNR, South Dakota Department of Environment and Natural Resources, and Nebraska Natural Resources Districts. Each database was first filtered by spatially selecting and exporting the point features into a geographic information system (GIS) using the Niobrara Basin boundary polygon (fig. 1) as a selection tool. Based on data attributes and guidance from officials responsible for the databases, the data were further filtered to eliminate abandoned or non-existent wells, identify and divide wells into use classes, and reduce redundancy between monitoring-well data sets.

\section{Geomorphic Segmentation of the Niobrara River}

The most basic function of a river channel is as a conduit to transport water and sediment. As a rule, an alluvial river channel adjusts its geometry to accommodate its supplied loads of sediment and water (Huang and Nanson, 2000). Geometric adjustments may be in the form of cross-section geometry and characteristics (width, depth, roughness), planform geometry (bars, banks, sinuosity, curvature), or channelbed slope (Knighton, 1998). Thus, it follows that channelgeometry adjustments are the result of a dynamic interaction between imposed sediment and water loads, and constraints on adjustment, such as valley confinement, bedrock lithology, or biological effects such as the binding root strength of riparian plants (Montgomery and Buffington, 1997; Wohl and Merritt, 2001; Gran and Paola, 2001). These differences in channel geometries (morphology) act as the template for aquatic and bottomland ecological processes (Naiman and others, 1993; Scott and others, 1996). It can be inferred, then, that changes in channel morphology may result in changes in ecological processes.

The Niobrara River channel in the study area is approximately $330 \mathrm{mi}$ long and changes dramatically in size and shape over its course. A goal of this investigation is to document and describe the segment-scale characteristics of the Niobrara River channel and its valley corridor within the study area. The authors use the term "segment" to describe a length of river that has a relatively uniform host of hydrologic and morphologic characteristics. River segments contain several channel reaches, which are variously defined, but commonly refers to a repeated sequence of hydraulic characteristics, such 
Table 2. Niobrara River tributaries and their percentage of contributing basin drainage area at their confluence with the main channel.

[All drainage area data based on United States Department of Agriculture-Natural Resource Conservation Service (2008) Watershed Boundary Dataset; mi, miles; DA, drainage area; $\mathrm{mi}^{2}$, square miles; --, not determined]

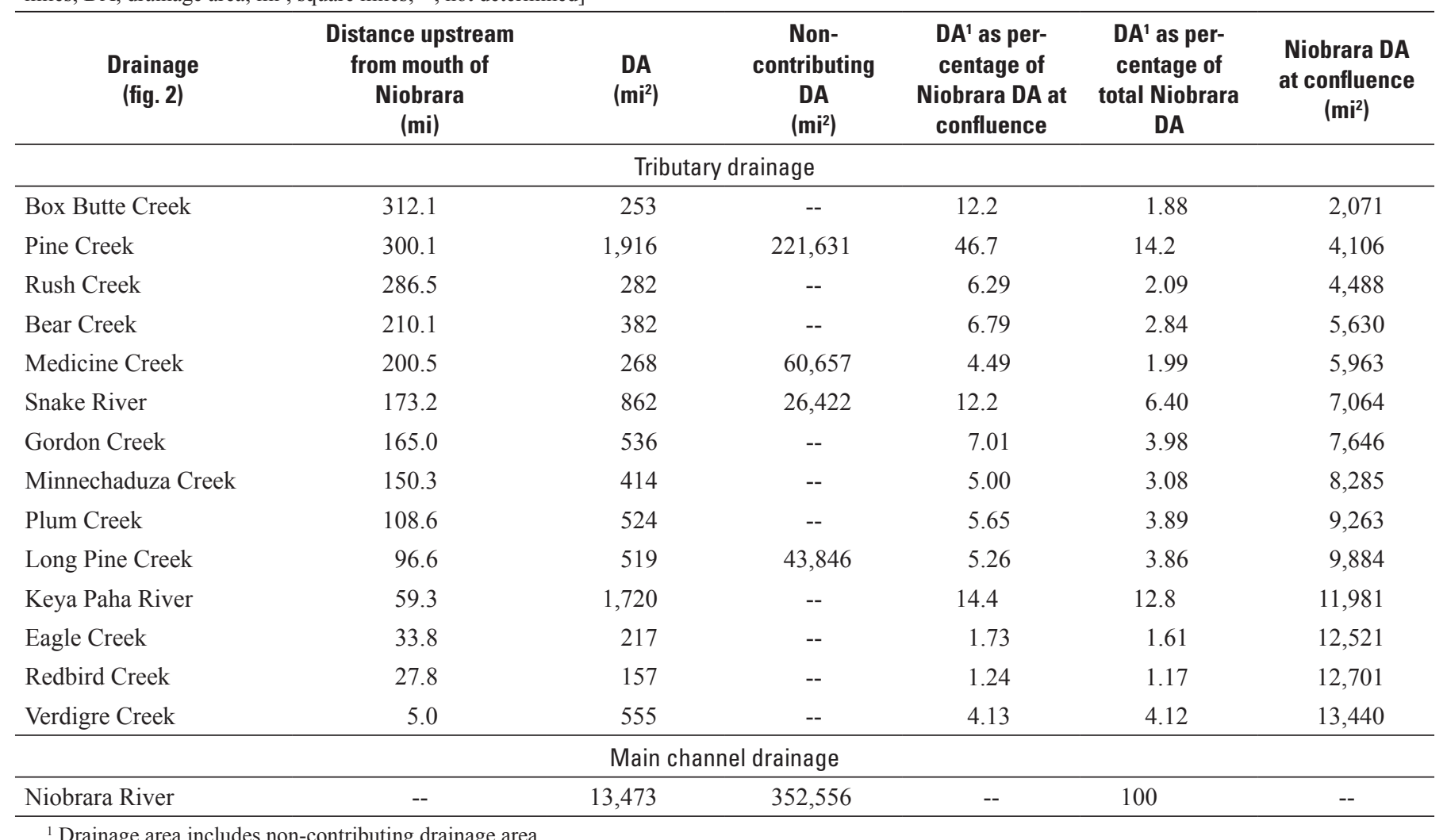

as a pool-riffle coupling (Frissell and others, 1986). The intention of the description is to provide an interpretive hydrogeomorphic framework to guide future, more detailed, scientific investigations. Geomorphic description and characterization of the Niobrara River was approached in three parts: (1) longitudinal segmentation using a geomorphic, process-oriented classification scheme; (2) longitudinal analysis of channel slope (hereinafter referred to as the "longitudinal profile"); and (3) longitudinal morphometric characterization. Within this report, the methods and some results from parts 1 and 2 are presented. Plans for complete results from part 2 and methods and results from part 3 are ongoing.

\section{Classification Scheme for Longitudinal Segmentation}

Classification, in general, is the process of grouping objects based on a pre-defined set of characteristics (Kondolf, 1995). River classification schemes range from purely form (shape)-based schemes, to inductive statistical procedures (Kondolf and others, 2003). Channel pattern classification schemes, such as those of Leopold and Wolman (1957), Schumm (1963), and Brice and Blodgett (1978), divide river channels into broad generalized types based on characteristics in channel planform. These channel types commonly are one of four: straight, meandering, braided, or anastomosing. These form-based schemes can be widely applied, and have a physical basis under the assumption that channel morphology is the integration of several physical processes including hydrologic, sediment, and vegetative effects. However, because these schemes are quite general, they are inadequate to describe other important effects on channel morphology, such as valley confinement or bedrock lithology. Some other form-based classification schemes, such as those of Rosgen (1994), provide more details of river and valley setting, but are, again, limited in their descriptive flexibility over large scales (Kondolf and Downs, 1996; Juracek and Fitzpatrick, 2003). Process-based classifications, similar to those of Montgomery and Buffington (1997), are more focused on the geologic and physiographic setting, and the host of associated physical processes that may affect the form of the river. Inductive statistical techniques such as those used by Elliot and Jacobson (2006), are process-orientated, and the most objective of techniques; however, such techniques are cumbersome to apply at the basin-scale, and best used when applied in combination with an analysis of temporal variation in channel form and process.

Because of the potentially unique qualities of the Niobrara River, a custom, process-orientated, classification scheme 
was developed to segment the river in the study area longitudinally. The purpose of the scheme was to act as a descriptive tool to assist in documenting the general range of channel and valley settings within the study area. The classification scheme and some of its results are presented herein as preliminary data. The final Niobrara River segments from the classification scheme are being derived and characterized as part of the ongoing study.

After careful examination of the Niobrara River using combinations of aerial photography, topographic maps, and professional judgment, four descriptive elements were chosen as the basic framework for the Niobrara River classification scheme: degree of valley confinement; channel planview pattern; channel width variation; and bar configuration. Each descriptive element contains three to four classes, which describe a range of conditions (table 3 ). Valley confinement was chosen to describe the affect of the valley width on channel shape, sediment supply, and overall channel adjustability. For example, in canyon reaches, the shape of the valley is the primary determinant of the channel shape, whereas in open meandering reaches, the valley shape has little to no effect. In canyon reaches, hillslope processes, such as landsliding, deliver sediment directly to the channel, whereas in openvalley settings, landslides are delivered to the floodplain (Montgomery and Buffington, 1997). Sinuosity was chosen as a descriptor of the degree of variation in channel direction. Whereas sinuosity is variously defined (Bridge, 2003), it is defined here as the ratio of the length of the channel centerline between two points to the length of a straight line drawn between the same two points. The authors use boundaries of 1.05 and 1.5 between straight and sinuous, and between sinuous and highly sinuous, respectively. Although these numerical boundaries have been used in other investigations (Wolman and Leopold, 1957), for the purposes of this study they were assigned based on natural data breaks, and have been calculated and named differently than those used previously. Because the Niobrara River is dominantly a ground-water-fed stream, the river may have significant gains in discharge, without a confluence from a major tributary. As such, the river also may have changes in width, without apparent changes in valley setting, curviness, or bar configuration. After examination of aerial photos of the Niobrara River, the authors also noted that several segments of the river had large shifts in channel width over short distances, potentially indicating loss or gain of discharge. Thus, width variation was chosen to describe changes in planform width within a segment. Finally, the configuration of sandbars is an important descriptor of channel processes such as a wandering thalweg, river meandering, multiple thalwegs, or anastomosing (Bridge, 2003). The authors use the terms alternate, lateral, braided, and islands respectively to indicate a dominance of one of these processes (Bridge, 2003).

Segmentation of the Niobrara River was accomplished by examination of the 2003 Farm Service Agency (FSA) natural color digital aerial photographs (1-meter $(\mathrm{m})(3.28 \mathrm{ft})$ resolution) (U.S. Department of Agriculture, 2004) in a GIS.
Boundaries of segments were digitized as points, and their associated classification conditions were attributed wherever a pronounced and persistent change in one of the four elements was recognized. In some cases, segment boundaries were not pronounced. In such cases, professional judgment was used, and the boundary placed near the midpoint of the gradient. The authors did not, as a rule, use tributary junctions as segment boundaries unless a morphologic change coincided with it. Whereas tributaries commonly are used as hydrologic boundaries, the effect of ground water in the Niobrara study area diffuses hydrologic boundaries. The authors recognize the fact that some, arguably all, of the descriptive elements are discharge-dependent, and therefore limit segmentation results to the condition and discharge of the river as viewed in the 2003 FSA digital aerial photographs. Because of the vast area covered by the aerial photographs, and the dominance of ground-water accretion as the main source of flow in the Niobrara River, flow rates varied in the area by both the date and location of the photographs. That said, the authors acknowledge that the dominance of ground-water discharge in the upper two-thirds of the study area buffers temporal variability in flow rates.

\section{Longitudinal Profile Analysis}

One of the ways a river may adjust its morphology to inputs of sediment and water is by variation in channel slope. Bedrock lithology, tributary deposits, and hillslope processes may act as first-order controls on channel slope (Montgomery and Buffington, 1997; Montgomery and Gran, 2001; Hanks and Webb, 2006). To examine the broad-scale slope characteristics of the Niobrara River, the longitudinal profile of the main channel of the Niobrara was plotted and compared to available geologic and topographic digital datasets that also spanned the study area. To create the longitudinal profile, the channel centerline was digitized between the high banklines using the 2003 FSA aerial photographs. The centerline was addressed using a linear referencing tool in a GIS with the starting point $(0.0 \mathrm{mi})$ at the former Chicago and Northwestern railroad bridge near the confluence of the Niobrara and Missouri Rivers. Where possible in this document, the authors have used English units because these are the most familiar and practical units used by the focus audience; however, for the purposes of this section we use metric units when referring to analysis of digital data sets, which are the most common native units of the data sets, and therefore the units in which the data were analyzed.

The channel centerline was overlaid on the 1998 USGS National Elevation Dataset 10-m (32.8-ft) digital elevation model (DEM) (http://seamless.usgs.gov), and elevations were sampled at points every $20 \mathrm{~m}$ (65.6 ft) along the channel centerline. In addition, elevation statistics were computed at the same points using a $15-\mathrm{m}$ ( $49.2 \mathrm{ft})$ radius buffer. An algorithm was applied in the downstream direction to eliminate elevation gains. This correction was necessary because the 10-m DEM did not have the elevational precision to capture 
Table 3. Segment-scale geomorphic classification system for the Niobrara River, Nebraska.

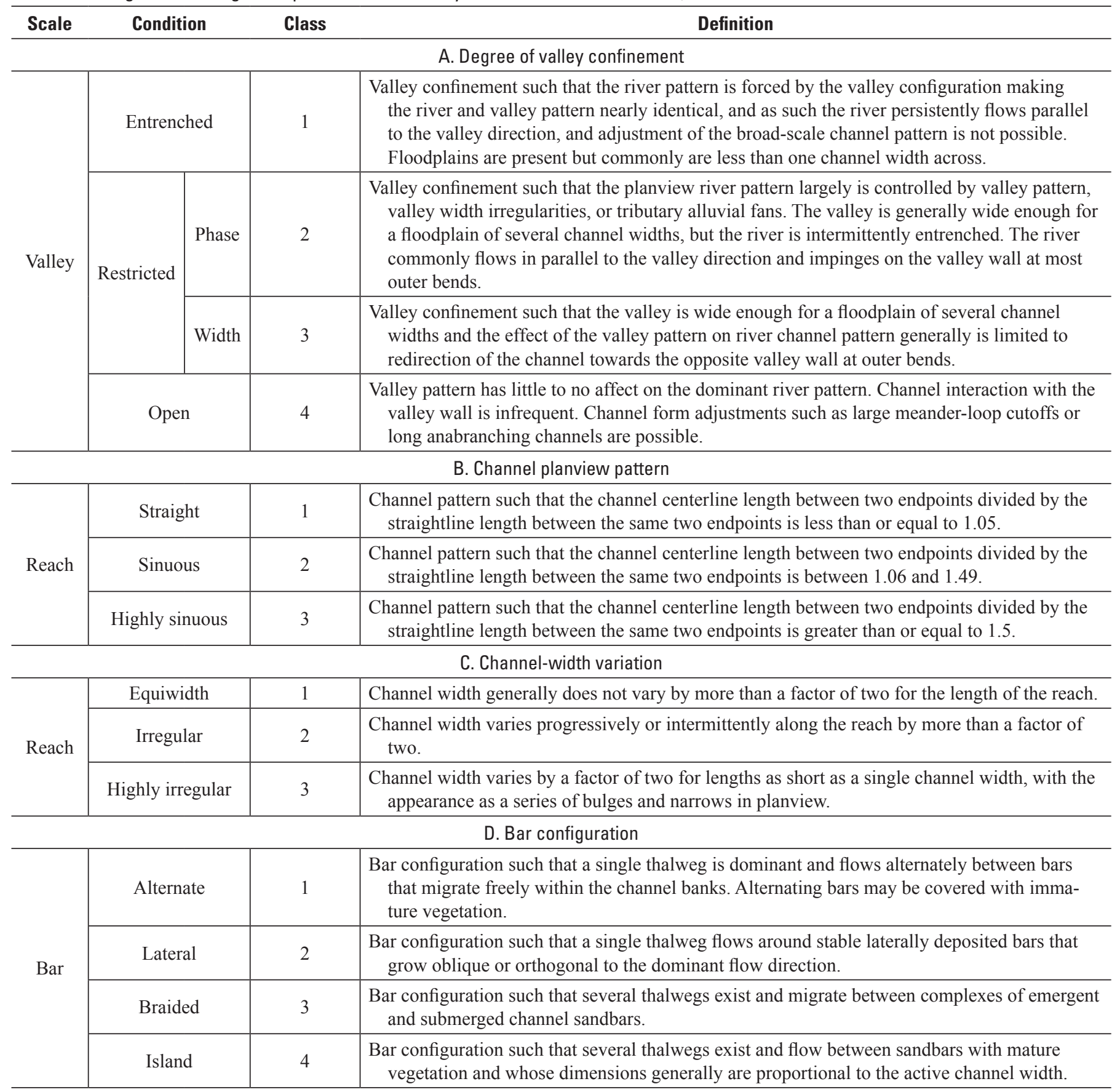

macro-scale channel bedforms such as pool-riffle sequences, and thus it was assumed that downstream elevational spikes were spurious. The algorithm applied the spatial statistics for any downstream point that was higher in elevation than its adjacent upstream point. The algorithm used trial and error, first assigning the mean, then the minimum of the elevation statistics; if neither the mean nor the minimum were lower than the elevation of the adjacent upstream point, the identical elevation of the upstream point was assigned. Whereas this correction forces a slope of zero between some points, it did not change the dominant local or broad-scale shape of the uncorrected original longitudinal profile. The longitudinal profile shape constructed from the USGS DEM also compares favorably with a more generalized profile constructed by Bentall (1991), which used the stream centerline and contour intervals from USGS 7.5-minute quadrangles.

Vertical position accuracy of the 10-m (3.28-ft) DEM is approximately equivalent to the root-mean-square error (RMSE) of the DEM. A RMSE less than one-half of the contour interval on the 7.5-minute quadrangle used was the maximum reported by the USGS and NDNR. Contour intervals for the study area vary, but typically are less than $20 \mathrm{ft}$, making 
the vertical accuracy of the DEM plus or minus $10 \mathrm{ft}$ (about $3 \mathrm{~m})$. At the scale of the study area, this constitutes less than 0.4 percent of the total longitudinal profile relief.

Comparisons of the Niobrara River longitudinal slope characteristics were made with two existing digital geographic data sets, both published by the University of NebraskaLincoln, Conservation and Survey Division (CSD) (1986): generalized bedrock geology of Nebraska and topographic regions of Nebraska. Contacts between bedrock lithologies and divisions between topographic regions were digitized and attributed along the channel centerline in a GIS. The point features were attributed with longitudinal locations using the address system of the Niobrara River channel centerline described above.

\section{Hydraulic Geometry Characterization}

To begin to understand how a river may adjust its geometry to changing discharges, examination of its current and historical behavior is a logical starting point (Kondolf and Downs, 1996). USGS and other agency streamflow-gaging stations provide a valuable, often temporally rich, empirical record of channel adjustment for a range of discharges at the local (cross-section) scale. The data contained in the basic field notes from a hydrographer's discharge measurement provide observations of water-top width, channel area, and average channel velocity, all of which are related to a particular discharge. Average channel depth can be calculated by dividing channel area by the water top width. Using the conventional methods described (see Background section in this report), these measures of channel geometry can be used to develop statistical models, termed "hydraulic geometry," which illustrate how a river channel at a particular location adjusts its geometry to accommodate a range of water discharges.

Other reports have documented that simple hydraulic geometry relations are inadequate to describe the changing conditions at a particular river reach, and have employed more complex relations (Rhodes, 1977; Eschner, 1983). Some authors have documented temporal trends in stream-rating relations with implications for hydraulic geometry (Chen and others, 1999). For the purposes of this report, the authors carefully employ simple hydraulic geometry relations to provide a baseline understanding of Niobrara River behavior relative to discharge at the basin scale. No attempt was made to track temporal trends, or adjustments relative to a particular stressor at any particular streamflow gage.

Although hydraulic geometry relations provide empirical evidence of channel adjustments, and hence a model of how a channel may respond to future changes in discharge, they are by no means a definitive predictor of such responses. The development and use of hydraulic geometry relations has several problems and limitations (Knighton, 1974; Park, 1977; Juracek and Fitzpatrick, 2008), some of which the authors encountered and wish to recognize here. First, discharge measurements are not always made at the same location. At stations where technicians measure discharge by wading the channel, the measurement location often is chosen based on safety and error considerations rather than the location of a previous measurement. The location of the measurement typically is recorded, but most often it is an estimate of distance from a local landmark (the gage house or a bridge), and is, therefore, neither accurate nor necessarily precise. This is particularly the case between distance estimates by different technicians. Thus, wading measurements may not be made at the same cross section, and differences in geometry between measurements made at a common discharge may be the result of natural spatial variability in channel dimensions rather than actual morphologic changes. At locations where measurements are made from a cableway or bridge, the problem of spatial variability is more limited, although differences in location can occur when technicians use different velocity measurement tools (Ginting and Zelt, 2008).

A second limitation of hydraulic geometry is the fact that streamflow-gaging station locations may not necessarily be representative of the channel environments upstream and downstream. Examples of this are gages located at bridges, which often are built at locations that are naturally narrower than the surrounding river, or may have causeways or elevated approaches, forcing the channel to narrow. Another example is a streamflow-gaging station downstream from a dam, which reduces sediment supply and, again, may not represent the channel environments upstream or further downstream, where sediment supplies are more in balance with the flow regime.

A third limitation of hydraulic geometry are the measurements themselves, which may be limited in range of flows, have varying degrees of uncertainty, and may be greatly affected by environmental conditions such as ice or debris. Although the quality of the measurement condition typically is rated by the hydrologic technician (Rantz and others, 1982), the rating is based on best professional judgment which is, again, subjective.

Finally, there is the fact that observations of past behavior are not a guarantee of future behavior, especially given the complexity of river systems and the uncertainty of prediction in natural systems (Simon and Castro, 2003). Even with these limitations in mind, the fact that measurement data are actual observations of past river behavior lends some credence to their value in assessing, at a minimum, the potential direction of channel adjustment associated with changing discharges in the future.

\section{At-A-Station Hydraulic Geometry Relations}

At-a-station hydraulic geometry relations describe how a river channel at a particular location (a cross section) adjusts to changing discharges. Hydraulic geometry relations were developed for eight individual streamflow-gaging stations located along the main channel of the Niobrara River in the study area (fig. 4). The relations were developed using methods first outlined in Leopold and Maddock (1953), using 
the forms of equations 1 through 3 described in the Background section of this report. The at-a-station relations of the form of equations 1 through 3 were developed using ordinary least-squares (OLS) regression of $\mathrm{x} / \mathrm{y}$ data pairs from hydrologic technician's measurement notes. In all cases " $x$ " was the discharge calculated from the measurement, and " $y$ " was either the channel-top width, the average channel depth (channel area divided by top width) or average channel velocity (discharge divided by channel area). The regression line slope value (exponent), regression line intercept value (coefficient), probability $(p)$ values, and coefficients of determination (COD) for all OLS at-a-station hydraulic geometry relations were generated using standard statistical tools in Microsoft Excel $^{\mathbb{}}$. OLS regression slope values were tested for statistical significance at the 90-percent confidence level; probability ( $p$ ) values less than 0.10 were interpreted to indicate that the slope coefficient generated for the at-a-station hydraulic geometry relation was significantly different than zero (a slope of zero would generally indicate that " $\mathrm{x}$ " is a poor or weak predictor of " $y$ "). The COD values for the OLS model, which indicate the fraction of the variance in the " $y$ " variable explained by a statistical model generated using the " $\mathrm{x}$ " variable as a predictor, was used as a secondary indicator of model goodnessof-fit. Raw data graphs of measurement data $x / y$ pairs, and 90-percent confidence bounds for all OLS at-a-station hydraulic geometry regression relations, were generated in S-plus statistical software and are presented in Appendix 2.
For streamflow-gaging stations downstream from the Snake River confluence, only measurements recorded after water year 1963 were used because operations of Merritt Dam began in water year 1964. A water year is defined as beginning on October 1 and ending on September 30 of the year indicated. Upstream from the Snake River confluence, post-1963 records were used where available; however, in most cases, only pre-1963 records were available.

Measurement data used to develop the at-a-station hydraulic geometry relations were the end result of a data filtering process intended to reduce data uncertainty. The initial data filter eliminated measurement data rated by the technician as "poor." Data with a poor rating are assumed to have greater than 10-percent uncertainty in the discharge magnitude (Rantz and others, 1982). The second filter eliminated measurement data that were made when the channel itself was not considered the main hydraulic control by the technician. Examples of this are when the channel is choked with ice or heavy debris.

A final filter step was applied that varied depending on whether or not the measurements were predominantly wading or from a bridge or cableway. If most of the measurements were wading, and the measurements included larger-magnitude flows (flows with lower exceedance frequencies), wading measurements were used in the hydraulic geometry relations. In such cases it was desirable to filter the data based on the hydrologic technician's note of the measurement location relative to a landmark. Location data were filtered by first

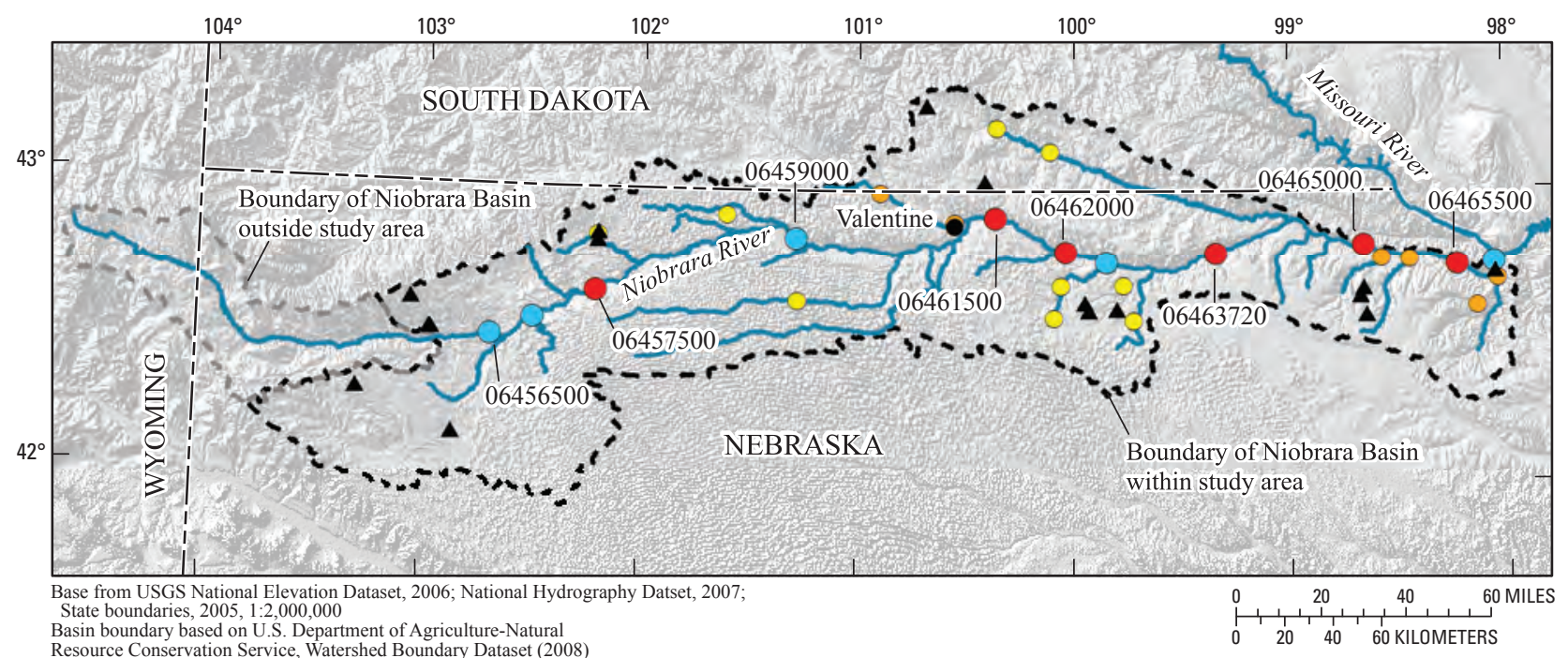

Resource Conservation Service, Watershed Boundary Dataset (2008)

Universal Traverse Mercator projection, zone 14

Horizontal coordinate information is referenced to
the North American Datum of 1983 (NAD 83)

EXPLANTION

- Crest-stage gage

Niobrara River gage discontinued before 1964

- Small-tributary gage

Large-tributary gage

Niobrara River gage with records after 1963

[Gaging stations with station number labels correspond to gages used for the hydraulic-geometry analysis (table 4)]

Figure 4. Streamflow-gaging stations in the Niobrara River Basin selected for data inventory. 
obtaining the statistical mode (the most frequently occurring observation) of the location data. The mode was then compared to other comments of location. For example, at one gage, two different measurement notes read "wading measurement $10 \mathrm{ft}$ below gage under cableway" and "wading measurement $50 \mathrm{ft}$ below gage under cableway." These two measurements would appear to have been made under two different cableways located $40 \mathrm{ft}$ apart; however, the location of the cableway did not change. In such cases, where two landmarks were used, it was assumed that all data with the label "under cableway" were at the same location, and therefore all data between 10 and $50 \mathrm{ft}$ in the same direction (upstream or downstream) away from the first landmark, the gage, were used for hydraulic-geometry analysis.

For measurements where no second landmark was noted, wading measurements were assumed to be at the same cross section if the measurement was within one-half the value of the statistical mode of measurement locations in either direction (upstream or downstream). For example, if the statistical mode was "50 ft below the gage," all measurements between $25 \mathrm{ft}$ below the gage and $75 \mathrm{ft}$ below the gage were used. In some cases, no location data were readily available for wading measurements, and the location filter could not be applied.

For stations where bridges or cableways were the dominant location of measurements, only data from either the bridge or cableway were used. At one location, the Niobrara River near Verdel, bridge measurements were moved from a decommissioned bridge to a new bridge upstream in water year 1986. In this case, the measuring locations were considered as two different stations, and two separate at-a-station hydraulic-geometry relations were developed; one for the 1964 to 1985 period of record, and one for the 1986 to 2007 record.

\section{Downstream Hydraulic-Geometry Relations}

Downstream hydraulic geometry relations describe how a river adjusts its geometry to gains in discharge in the downstream direction (as drainage area increases). Downstream hydraulic geometry relations were developed for the Niobrara River using methods described by Leopold and Maddock (1953) and using the simple power equations 1 through 3 (in the Background section of this report) as statistical models. Average daily discharge for each at-a-station streamflowgaging station was used to generate flow-duration curves (fig. 5). With the exception of the Verdel gages, the same periods of record as the measurement data used for the at-a-station relations were used to generate the flow-duration curves. At the Verdel gages, the authors assumed that, although the location of the streamflow-gaging station moved in water year 1986, the flow record applied to both locations because of their close proximity. Therefore, the entire post- 1963 period of record was used to generate a flow-duration curve, which was applied to both of the Verdel at-a-station hydraulic geometry relations.
Three exceedance frequencies, 10, 50, and 75 percent, were chosen to represent the high-, median-, and low-flow magnitudes respectively (table 4). Mean annual flow (also known as mean daily flow) also was calculated for the period of record for each gaging station. Common exceedance flows were used as predictor variables to generate hydraulic geometry values (channel-top width, average depth, and average velocity) using the at-a-station hydraulic-geometry relations from each streamflow-gaging station. Downstream hydraulicgeometry relations were then generated for each exceedance frequency using OLS regression of the " $x$ " (discharge of common exceedance frequency) and " $y$ " (at-a-station width, average depth, or average velocity) data pairs from each of the streamflow-gaging stations. OLS regression slope values, coefficient values, $p$ values, and COD were generated using procedures identical to those described above for the at-astation hydraulic-geometry relations.

\section{Hydraulic Habitat at a Streamflow-Gaging Station}

At the scale of a river reach, hydraulic variables such as flow depth and velocity exert important effects on the types of aquatic habitat available for organisms, and even moderate alteration can produce significant shifts in habitat availability (Stalnaker and others, 1996; McKenny, 1997; Maddock, 1999). For the purposes of demonstration, hydraulic microhabitat calculations were performed using the automated computational tool presented in Ginting and Zelt (2008). The tool characterizes the extent of hydraulic habitat niches along the cross section using a matrix of three depth and three velocity classes (table 5). Depth classes are defined as shallow, intermediate, and deep, corresponding to class boundaries of less than $1 \mathrm{ft}, 1$ to $2 \mathrm{ft}$, and deeper than $2 \mathrm{ft}$, respectively. Velocity classes are defined as slow, moderate, and swift, corresponding to class boundaries of less than $1 \mathrm{ft}$ per second, 1 to $2 \mathrm{ft}$ per second, and greater than $2 \mathrm{ft}$ per second, respectively. The hydraulic habitat nomenclature uses the respective depth and velocity class names. For example, an area of the channel with depth less than $1 \mathrm{ft}$ and velocity between 1 and $2 \mathrm{ft}$ per second would be classified as "shallow-moderate." Although the hydraulic habitat niches originally were defined for fish species of the Platte River (Peters and Holland, 1992), many of the same fish species have been sampled in the main channel and tributaries of the Niobrara National Scenic River (Dietsch, 2007).

To compare differences in habitat types and distributions, three different flow magnitudes were chosen to represent the upper decile (less than 10-percent exceedance), median quantile (25- to 75-percent exceedance), and lower decile (greater than 90-percent exceedance) of flows at the USGS streamflowgaging station on the Niobrara River near Sparks, Nebraska (station number 06461500). This gage was chosen because of its location within the 76-mi National Scenic River Reach and its representativeness of the narrow canyon environments 
Table 4. Flow-exceedance frequencies and associated discharges used for downstream hydraulic-geometry calculations.

$\left[\%\right.$, percent; $\mathrm{ft}^{3} / \mathrm{s}$, cubic feet per second; all place names mentioned are in the State of Nebraska]

\begin{tabular}{|c|c|c|c|c|c|c|}
\hline Streamflow gaging-station name & $\begin{array}{l}\text { Station } \\
\text { number }\end{array}$ & $\begin{array}{l}\text { Period of } \\
\text { record }^{1}\end{array}$ & $\begin{array}{c}\text { Mean annual }{ }^{2} \\
\text { discharge in } \\
\mathrm{ft}^{3} / \mathrm{s}\end{array}$ & $\begin{array}{c}10 \% \\
\text { exceedance }^{3} \\
\text { discharge in } \mathrm{ft}^{3} / \mathrm{s}\end{array}$ & $\begin{array}{l}50 \% \text { exceedance } \\
\text { discharge in } \mathrm{ft}^{3} / \mathrm{s}\end{array}$ & $\begin{array}{l}75 \% \text { exceedance } \\
\text { discharge in } \mathrm{ft}^{3} / \mathrm{s}\end{array}$ \\
\hline Niobrara River near Hay Springs & 06456500 & $1951-1963$ & 29 & 40 & 24 & 18 \\
\hline Niobrara River near Gordon & 06457500 & $1964-1990$ & 110 & 155 & 102 & 85 \\
\hline Niobrara River near Cody & 06459000 & 1949-1956 & 315 & 400 & 302 & 258 \\
\hline Niobrara River near Sparks & 06461500 & 1964-2007 & 738 & 1,000 & 726 & 567 \\
\hline Niobrara River at Mariaville & 06463720 & $1986-1990$ & 1,360 & 1,875 & 1,250 & 1,080 \\
\hline Niobrara River near Spencer & 06465000 & $1964-2000$ & 1,536 & 2,375 & 1,400 & 1,060 \\
\hline Niobrara River near Verdel ${ }^{4}$ & 06465500 & $1964-2007$ & 1,708 & 2,695 & 1,540 & 1,180 \\
\hline
\end{tabular}

${ }^{1}$ Period of record is given in water years, defined as October 1 to September 30 and ending in the calendar year indicated.

${ }^{2}$ Mean annual discharge refers to the average of daily mean discharge values over the course of a water year.

${ }^{3}$ Exceedance refers to the percentage of days annually that mean daily discharge exceeds the given value.

${ }^{4}$ Gage near Verdel moved in water year 1985; exceedance-frequency values computed using entire period of record.

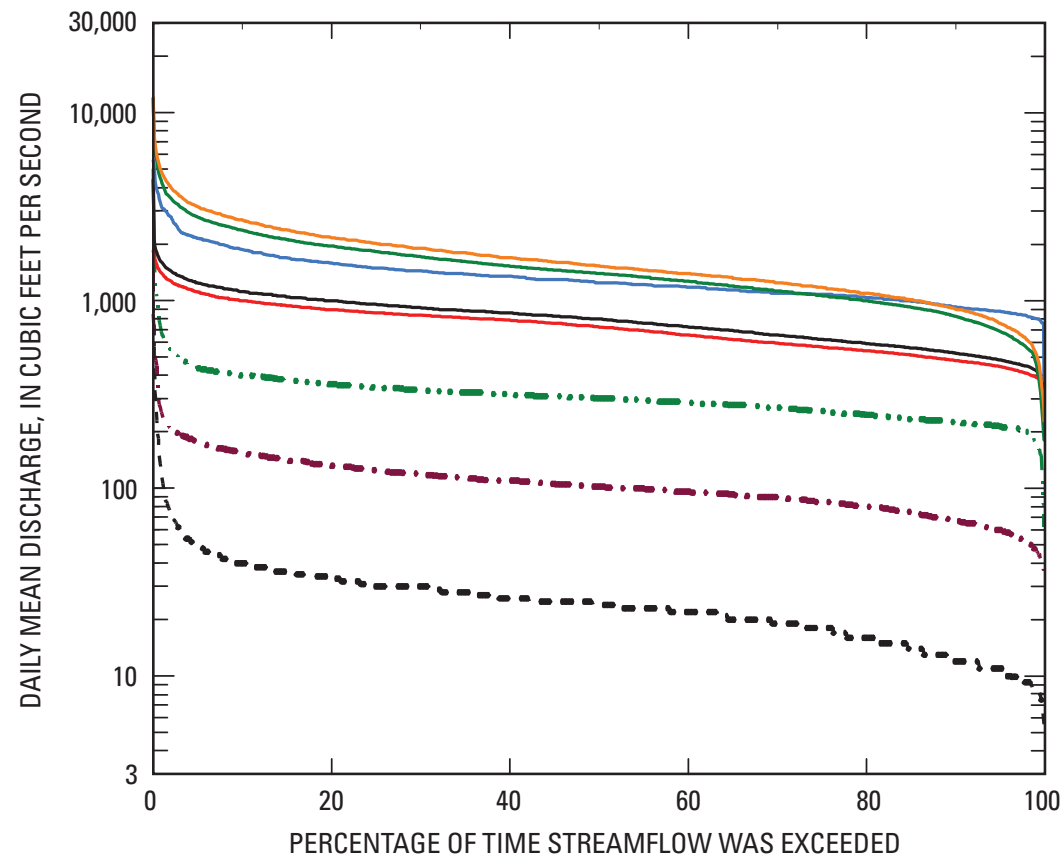

EXPLANATION

Niobrara River

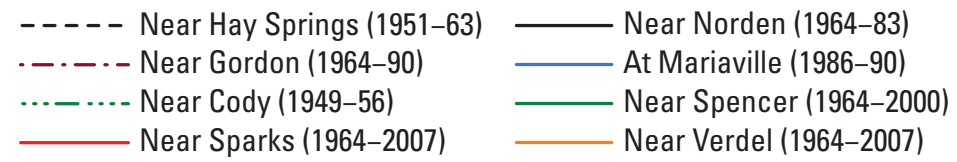

Figure 5. Flow-duration curves for selected streamflow gages and periods of record of the Niobrara River between Dunlap Diversion Dam and the Missouri River, Nebraska. 
Table 5. Matrix of depth and velocity combinations used to define hydraulic-habitat niches for microhabitat analysis using streamflow measurement data (from Ginting and Zelt, 2008).

[Depth and velocity classes and associated species based on Peters and Holland (1992), except where indicated; ft/s, feet per second; ft, foot]

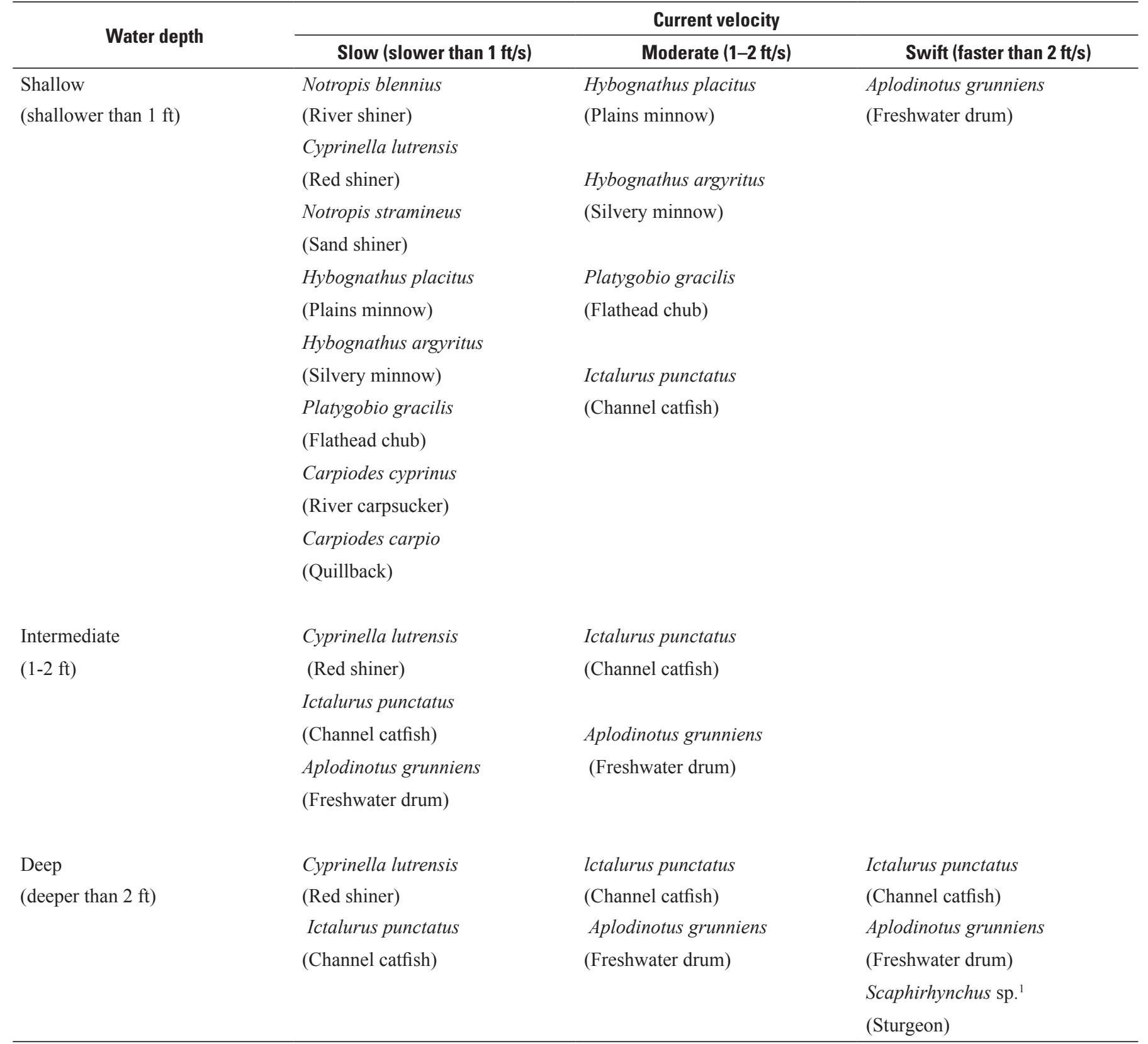

\footnotetext{
${ }^{1}$ Based on studies by Bramblett and White (2001) and Wildhaber and others (2007); the Deep-Swift niche is the preferred habitat requirements by pallid sturgeon (Scaphirhynchus albus) and shovelnose sturgeon (Scaphirhynchus platorynchus) during their adult life.
} 
Table 6. Discharge measurements and associated flow frequencies at Niobrara River near Sparks, Nebraska, used in hydraulic-microhabitat calculations.

[ $\mathrm{ft}^{3} / \mathrm{s}$, cubic feet per second]

\begin{tabular}{lccl}
\hline \multicolumn{1}{c}{ Date } & $\begin{array}{c}\text { Discharge } \\
\left(\mathbf{f t}^{3} / \mathbf{s}\right)\end{array}$ & $\begin{array}{c}\text { Percent } \\
\text { exceedance }\end{array}$ & $\begin{array}{c}\text { Flow frequency } \\
\text { quantile }\end{array}$ \\
\hline $8 / 17 / 1988$ & 467 & 92 & Lower decile \\
$9 / 9 / 2003$ & 446 & 95 & Lower decile \\
$7 / 20 / 1988$ & 605 & 78 & Median quantile \\
$6 / 20 / 2003$ & 749 & 57 & Median quantile \\
$4 / 28 / 1988$ & 1,030 & 8 & Upper decile \\
\hline
\end{tabular}

within the basin. Three flows from water year 1988 were chosen because they referenced the same cross-section location in the same year, and all three measurements occurred after winter ice breakup (table 6). Comparisons also were made with time at the Sparks gage, using lower-decile and medianquantile flows from water year 2003. The upper-decile flow measurements were not made at a common cross section in 2003 , and therefore could not be used in the analysis.

\section{Initial Results}

\section{Summary of Available Data}

\section{Stream Hydrology and Sediment}

All active and inactive streamflow-gaging stations for the Niobrara study area are listed in table 7 . The inventory includes 45 streamflow-gaging stations. Of those, 29 gages were, at one time or another, continuous-record stations, where daily flows were recorded using a stage recorder, and where discharge measurements were made several times annually. Sixteen of the 45 stations are listed as crest-stage gages. Crest-stage gages within the study area generally are located in smaller basins, along intermittent creeks, and loworder streams (fig. 4). Of the 29 continuous-record stations, 13 have records of suspended sediment; 8 are along the main channel of the Niobrara River; and 5 are within large tributaries. In addition, all but one of the continuous-record stations had available discharge-measurement field notes, and many have at least some water-quality data. Of the 28 gages with discharge-measurement field notes available, 15 have notes available after 1963 (table 8); most of these sites are in the downstream portion of the study area.

\section{Ground-Water Hydrology}

At the time of publication, more than 11,400 groundwater wells were identified as "active" (not including geologic test holes) within the Niobrara study area (table 9). Water- supply wells, which include irrigation, commercial, industrial, and minor-use wells (domestic, stock, and aquaculture supply wells) constitute most of the wells in the basin. Irrigation and commercial-supply wells are concentrated in the Nebraska Sand Hills region south of the river, near O'Neill, Nebr., and south of Dunlap Diversion Dam (fig. 6A). Domestic and stocksupply wells, which the authors refer to as "minor-use" wells, are focused in the area immediately around Valentine, Nebr., and to the southeast near Long Pine, Nebr. (fig. 6B).

Approximately 1,400 wells were identified as "active" within the USGS NWIS database. These wells have been used for various scientific observations (ground-water levels, aquifer tests, water-quality sampling). Nebraska wells in the NWIS database have the potential to be redundant with wells contained in the NDNR well database; however, without a common identifier between the two databases, no mechanism exists to readily eliminate redundancy.

A network of ground-water elevation monitoring wells is maintained in the study area (fig. $7 A$ ). In South Dakota, the Department of Environment and Natural Resources monitors ground-water levels in approximately 39 wells several times a year (Ken Buhler, South Dakota Department of Environment and Natural Resources, oral commun., 2008); these wells are concentrated mainly in the Keya Paha River Basin. In Nebraska, three Natural Resources Districts (Upper Niobrara-White, Middle Niobrara, and Lower Niobrara) maintain 218 observation wells throughout the study area, which are monitored for ground-water elevation in the spring and fall annually (Lynn Webster, Upper Niobrara-White Natural Resources District, oral commun., 2008). The records for these wells generally are limited to the past 10 years, although several of the monitoring wells have records extending back several decades.

Within the study area, 2,162 boreholes were identified as geologic "test holes" (table 8). Within Nebraska, University of Nebraska-Lincoln Conservation Survey Division (CSD) maintains a database of geologic test holes. Within the Nebraska part of the study area, 255 geologic test holes were identified; many of the geologic test holes are aligned in north-south series, and have been drilled since 1930 by CSD and used to identify bedrock geologic contacts and define aquifer physical and hydraulic properties (fig. 7B). The South Dakota Geological Survey maintains a public database of geologic test holes specifically drilled for the purpose of describing lithology; within the South Dakota part of the study area, 1,907 wells were identified. The South Dakota database of well-completion reports also contains lithologic logs for water-supply and explorations wells, although these were not included in the inventory.

Although numerous wells and geologic test holes exist in the Niobrara study area, well density along the main channel and tributaries is approximately one per square mile. Such density provides little value for tests of stream-aquifer interactions; however, broad-scale piezometric surfaces may be generated and identify generalized locations of gains or losses, or recent temporal trends in ground-water table elevations. 
Table 7. Active and inactive streamflow-gaging stations of the Niobrara River Basin study area.

[Gages listed in order from upstream to downstream; trib., tributary; USGS, U.S. Geological Survey; NDNR, Nebraska Department of Natural Resources; present, record through water year 2007; unless indicated otherwise, all stations are located in Nebraska; *, gage reinstated in water year 2008; records available: 1 - daily discharge, 2 - peak streamflow, 3 - discharge-measurement field notes, 4 - suspended sediment, 5 - water quality, 6 - water temperature]

\begin{tabular}{|c|c|c|c|c|}
\hline Station name & Station number & $\begin{array}{c}\text { Period of record } \\
\text { (water years) }\end{array}$ & Operator & Records available \\
\hline \multicolumn{5}{|c|}{ Continuous-record stations } \\
\hline Niobrara River near Hay Springs ${ }^{1}$ & 06456500 & $1950-64$ & USGS & $1,2,3,4,5$ \\
\hline Niobrara River near Gordon ${ }^{1}$ & 06457500 & $1928-32,1946-93$ & USGS, NDNR & $1,2,3,4$ \\
\hline Bear Creek near Eli & 06458500 & $1948-53$ & USGS & $1,2,3$ \\
\hline Snake River above Merritt Reservoir & 06459200 & $1962-81$ & USGS & $1,2,3,6$ \\
\hline Snake River near Burge & 06459500 & $1947-2004$ & USGS, NDNR & $1,2,3,4$ \\
\hline Niobrara River near Valentine & 06460500 & $1928-32$ & USGS & 3 \\
\hline Minnechaduza Creek near Kilgore & 06460900 & $1958-74$ & USGS & $1,2,3$ \\
\hline Minnechaduza Creek at Valentine & 06461000 & 1947-94 & USGS, NDNR & $1,2,3$ \\
\hline Long Pine Creek near Long Pine & 06463080 & 1980-91 & USGS & $1,2,3$ \\
\hline Long Pine Creek near Riverview & 06463500 & 1948-Present & USGS, NDNR & $1,2,3,4,5,6$ \\
\hline Niobrara River at Mariaville $^{1}$ & 06463720 & $1986-91$ & USGS & $1,2,3,4,5,6$ \\
\hline Keya Paha River near Hidden Timber, South Dakota & 06464000 & $1948-52$ & USGS & $1,2,5,6$ \\
\hline Keya Paha River near Keya Paha, South Dakota & 06464100 & 1981-Present & USGS & $1,2,3,4,6$ \\
\hline Keya Paha River at Wewela, South Dakota & 06464500 & 1938-40, 1947-Present & USGS & $1,2,3,4,5,6$ \\
\hline Keya Paha River near Naper & 06464900 & $1958-2004$ & USGS, NDNR & $1,2,3$ \\
\hline Niobrara River near Spencer ${ }^{1}$ & 06465000 & $1908-2002 *$ & USGS & $1,2,3,5,6$ \\
\hline Eagle Creek near Redbird & 06465310 & 1979-92 & USGS & $1,2,3,5,6$ \\
\hline Redbird Creek at Redbird & 06465440 & $1981-94$ & USGS & $1,2,3$ \\
\hline Cottonwood Creek near Dunlap & 06456400 & $1948-78$ & USGS & 2 \\
\hline Point of Rocks Creek near Marsland & 06457100 & $1970-78$ & USGS & 2 \\
\hline Berea Creek near Alliance & 06457200 & $1953-78$ & USGS & 2 \\
\hline Antelope Creek at Gordon & 06457700 & $1953-70$ & USGS & 2 \\
\hline Antelope Creek trib. near Gordon & 06457800 & $1953-78$ & USGS & 2 \\
\hline Bone Creek trib. near Ainsworth & 06463100 & $1956-68$ & USGS & 2 \\
\hline Bone Creek trib. No. 2 near Ainsworth & 06463200 & $1958-68$ & USGS & 2 \\
\hline Sand Draw tributary near Ainsworth & 06463300 & $1956-74$ & USGS & 2 \\
\hline Antelope Creek near Mission, South Dakota & 06463900 & 1990-2006 & USGS & 2,6 \\
\hline Sand Creek near Olsonville, South Dakota & 06464120 & 1999-2007 & USGS & 2,6 \\
\hline Honey Creek near O’Neill & 06465200 & $1958-68$ & USGS & 2 \\
\hline Camp Creek near O’Neill & 06465300 & $1958-78$ & USGS & 2 \\
\hline Blackbird Creek trib. near O’Neill & 06465400 & $1958-68$ & USGS & 2 \\
\hline Bingham Creek near Niobrara & 06465850 & $1968-78$ & USGS & 2 \\
\hline
\end{tabular}

\footnotetext{
${ }^{1}$ Gage used in hydraulic geometry analysis.
} 

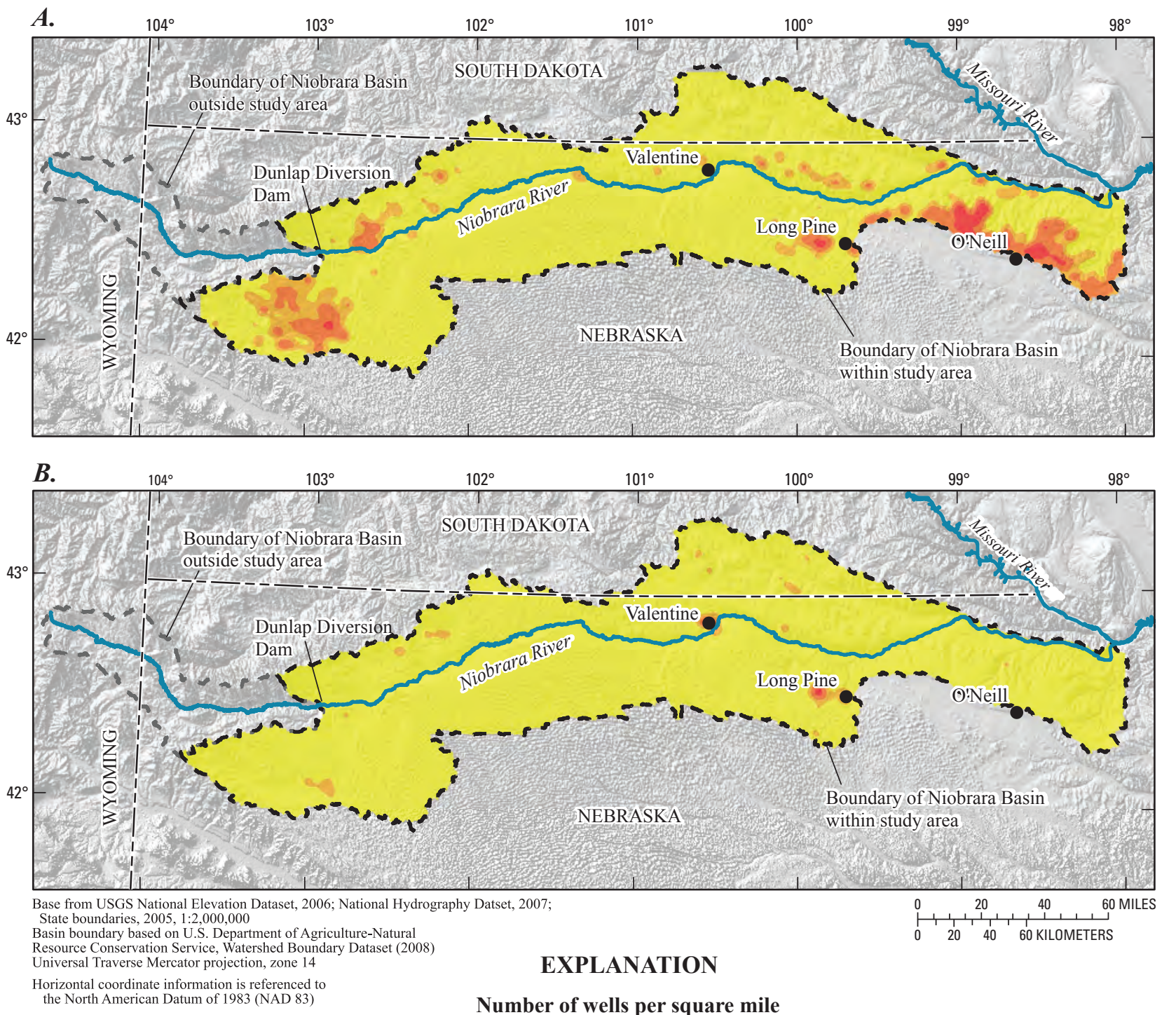

$102^{\circ}$

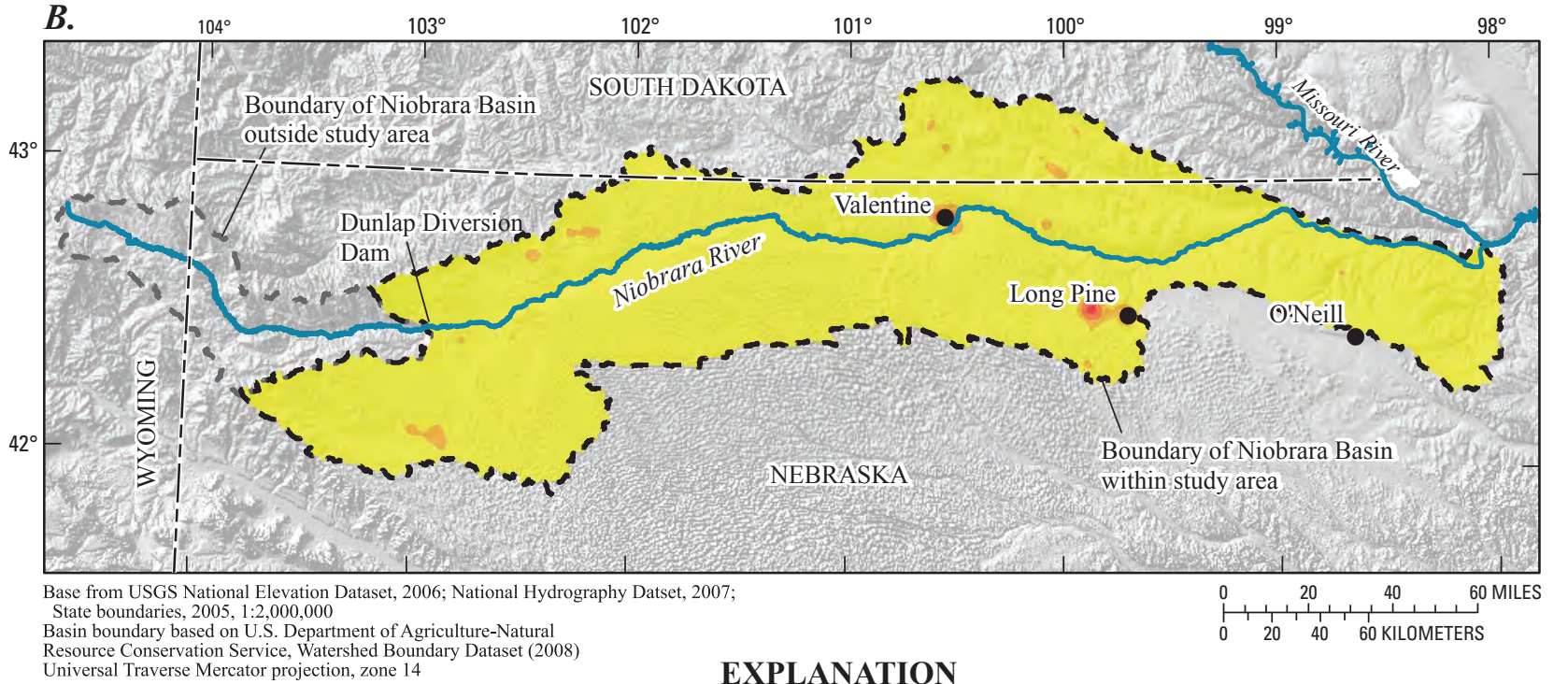

Number of wells per square mile

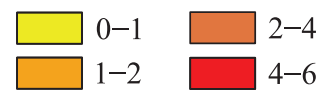

Figure 6. Ground-water well density in the Niobrara River study area (A) Irrigation and commercial-supply wells; and $(B)$ minor-use wells (domestic, stock, and aquaculture supply wells).

\section{Characteristics of Geomorphic Segments}

\section{Longitudinal Segmentation}

Using the descriptive elements outlined in table 3 , the portion of the Niobrara River in the study area was divided into 36 individual segments (table 10). Three fluvial geomorphic provinces can be inferred based on natural breaks in the condition classes of the segments: an upper province dominated by open valleys and a sinuous, equiwidth channel; a central province with mixed valley and channel settings, including several entrenched canyon reaches; and a lower province with a wide, yet restricted, valley and a wide, persistently braided, or island-dominated channel. In this report, these provinces are called the meandering bottoms $(\mathrm{MB})$, canyons and restricted bottoms (CRB), and braided bottoms (BB), respectively. The boundaries of these provinces roughly correspond to the boundaries of the "valleys" and "escarpments and bluffs" topographic provinces published by University of NebraskaLincoln, Conservation Survey Division (1986) (fig. 8). Additionally, the boundary between CRB and BB roughly corresponds to the boundary between bedrock of Tertiary and Cretaceous age, also published by University of NebraskaLincoln, Conservation Survey Division (1986).

Mean segment length increases in the downstream direction, with $\mathrm{MB}$ segments averaging $5.3 \mathrm{mi}$, CRB segments averaging $7.1 \mathrm{mi}$, and $\mathrm{BB}$ segments averaging $20.8 \mathrm{mi}$ long (table 9). Width-restricted valley settings are the most frequent 
Table 8. Inventory of hydrographer's discharge measurement notes at Niobrara River Basin gaging stations with records after 1963.

[Gages listed upstream to downstream; USGS, U.S. Geological Survey; NDNR, Nebraska Department of Natural Resources; NDEQ, Nebraska Department of Environmental Quality; no., number; --, no data; all stations are located in Nebraska]

\begin{tabular}{|c|c|c|c|c|c|}
\hline \multirow{3}{*}{ Station name } & \multirow{3}{*}{$\begin{array}{l}\text { Station identification } \\
\text { code or number }\end{array}$} & \multicolumn{3}{|c|}{ Period of record available (water years) } & \multirow{3}{*}{$\begin{array}{c}\text { Total no. of } \\
\text { measurements }\end{array}$} \\
\hline & & \multicolumn{3}{|c|}{ Custodian of measurement notes } & \\
\hline & & USGS & NDNR & NDEO & \\
\hline Niobrara River near Gordon ${ }^{1}$ & 06457500 & -- & 1964-1994 & 2003 & 721 \\
\hline Snake River near Burge & 06459500 & $1964-93$ & 1994-2007 & -- & 697 \\
\hline Niobrara River near Sparks ${ }^{1}$ & 06461500 & 1964-2007 & -- & -- & 618 \\
\hline Niobrara River near Norden ${ }^{1}$ & 06462000 & $1964-87$ & -- & -- & 388 \\
\hline Plum Creek at Meadville & 06462500 & $1967-95$ & -- & -- & 450 \\
\hline Long Pine Creek near Riverview & 06463500 & 1964-2007 & -- & -- & 672 \\
\hline Niobrara River at Mariaville $^{1}$ & 06463720 & $1985-92$ & -- & -- & 92 \\
\hline Redbird Creek at Redbird & 06465440 & $\begin{array}{l}1977-78 \\
1981-95\end{array}$ & -- & -- & 211 \\
\hline Niobrara River near Verdel ${ }^{1}$ & 06465500 & 1964-2007 & -- & -- & 648 \\
\hline Verdigre Creek near Verdigre & 06465700 & $2002-07$ & -- & -- & 49 \\
\hline
\end{tabular}

${ }^{1}$ Gage used in hydraulic-geometry analysis.

type of segment and the most widespread within the study area. Open valleys are intermittent downstream from the MB province, occurring as abrupt convexities in valley bottom width. Nearly all segments are sinuous in channel pattern and none meet the criteria of "straight." Three reaches meet the criteria of "highly sinuous:" two in open valleys, and one within an entrenched canyon segment. Irregular width patterns are the most frequent among channel segments, although highly irregular width patterns dominate the extent of the study area. Finally, alternate bars are the most frequent bed forms present among geomorphic segments, but braided bars cover most of the channel bed in the study area. Island-dominated reaches are uncommon, occurring mainly in the backwater segments above Spencer Dam and the delta region near the Missouri River (Etheridge and others, 1999).

\section{Longitudinal Profile Characteristics of the Niobrara River}

Channel slope of the Niobrara River study area varies between 0.05 and 0.25 percent among segments, with a studyarea mean of 0.15 percent (tables 10 and 11). Among geomorphic provinces, channel slope is steepest and most variable in the $\mathrm{MB}$; however, the $\mathrm{CRB}$ province has the widest range among segment slopes. The BB province exhibits the mildest, least-variable slopes among the three provinces, with a maximum slope approximately equivalent to the study-area mean.
Slope characteristics and perturbations of slope in the longitudinal profile of the Niobrara River indicate that bedrock may be an important control in channel form. At least two knick zones (locations of channel steepening) exist within the study area, both within the CRB province, and both roughly corresponding to bedrock contacts (fig. 8). Within the upstream knick zone, between Antelope and Bear Creeks, the Niobrara flows through a long series of entrenched meanders. Upstream from this knick zone, no major bedrock contacts occur in the study area, and the slope of the river is approximately the study-area mean. Near the downstream knick zone, between Medicine Creek and Snake River, several small, denuded tributaries deliver sediment directly to the river from the tablelands north of the river. An additional indicator of the effect of bedrock on Niobrara channel slope is the reduction in slope, and reduced slope variation, downstream from the contact between the White River Group and the Pierre Shale. This location also roughly corresponds to the boundary between the $\mathrm{CRB}$ and $\mathrm{BB}$ geomorphic provinces. Additional analysis is necessary to verify the effect of bedrock on channel geometry.

In addition to the effect of bedrock on channel slope, tributary alluvial sediment contributions also may cause local perturbations in slope. Within the CRB geomorphic province the longitudinal profile has a consistent stair-step pattern. Visual examination of the longitudinal profile indicates that many of the tributary confluences are located at or near the top of steps. Although this pattern has been shown in other 

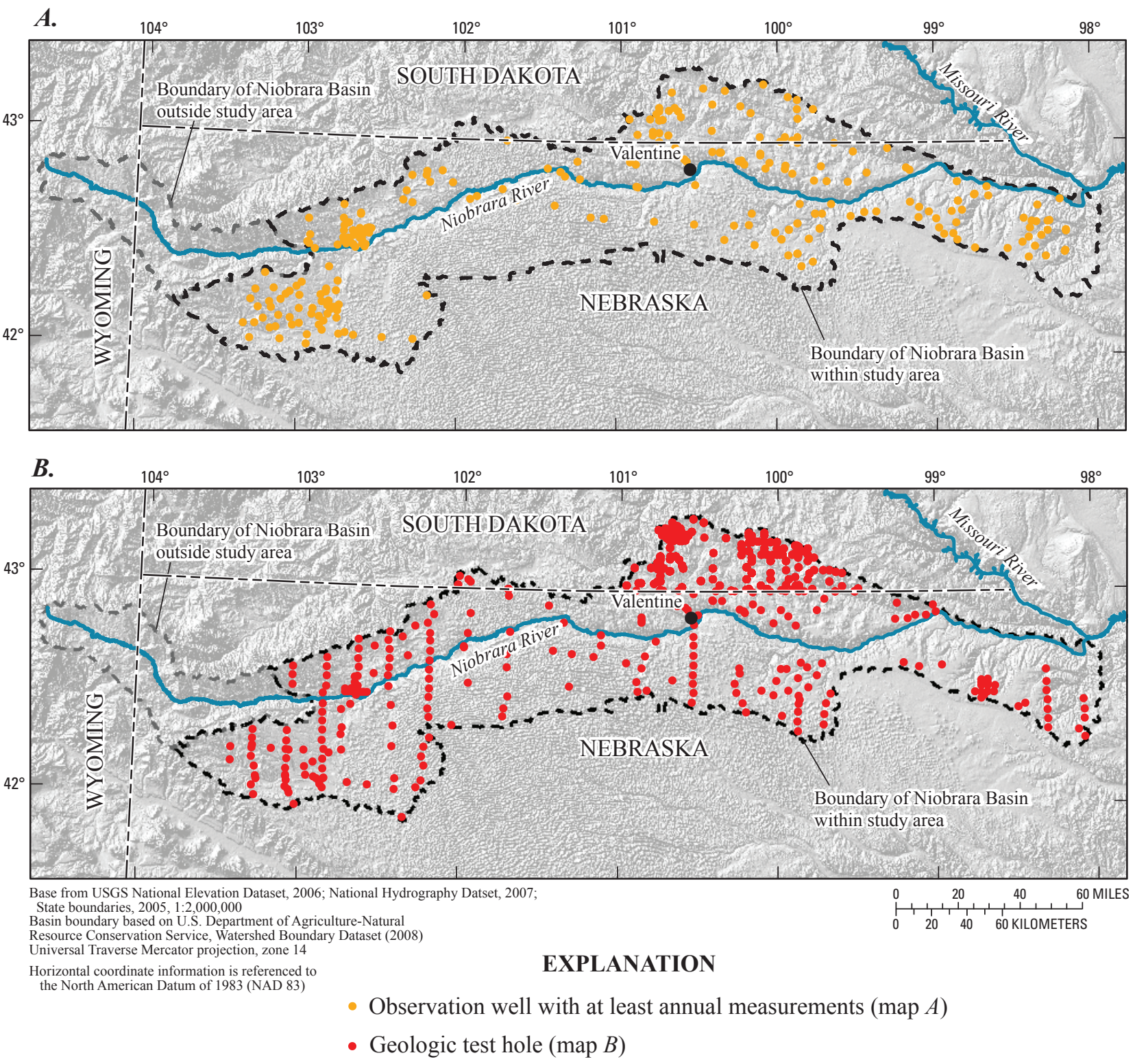

Figure 7. Ground-water observation wells and geologic test holes in the Niobrara River study area. (A) Active groundwater observation wells monitored at least annually for water-table elevation; and $(B)$ Geologic test holes with depth-tobedrock data.

locations to be the result of tributary sediment contributions (Grams and Schmidt, 1999; Hanks and Webb, 2006), the low precision of the 10-m DEM and the forcing of local slope values by the slope algorithm did not allow this hypothesis to be verified.

\section{Hydraulic Geometry}

The magnitude of the coefficients calculated for hydraulic-geometry models depend largely on the geometry and adjustability of the cross section (Turowski and others, 2008). For example, a box culvert will have no relation between increasing discharge and width for any discharge above that which fully covers the bottom with water. The same culvert will, however, have a strong relation with depth. To provide the reader with some visual and quantitative context for the hydraulic-geometry relations described below, detailed descriptions, photos, and detailed hydraulic-geometry plots for each streamflow-gaging station are included in the appendixes.

\section{At-A-Station Hydraulic-Geometry Relations for Selected Niobrara River Streamflow- Gaging Stations}

The graphical summaries of at-a-station hydraulicgeometry relations for Niobrara streamflow-gaging stations 
Table 9. Inventory of ground-water wells and test holes in the Niobrara River study area by state and usage type.

[NDNR, Nebraska Department of Natural Resources; CSD, University of Nebraska-Lincoln, Conservation and Survey Division; NRD, Nebraska Natural Resources Districts; USGS, U.S. Geological Survey; NWIS, National Water Information System; SDDENR, South Dakota Department of Environment and Natural Resources]

\begin{tabular}{|c|c|c|c|}
\hline Usage type & Count & Source & Description \\
\hline \multicolumn{4}{|c|}{ Nebraska } \\
\hline Irrigation, commerical, industrial & 5,635 & NDNR & Irrigation, commerical, and industrial-use water-supply wells. \\
\hline Regional ground-water observations & 218 & NRD, USGS & $\begin{array}{l}\text { Cooperative network of ground-water-level observation wells. Most } \\
\text { wells in this network have at least one measurement of ground- } \\
\text { water elevation per year. Period of record is variable, although all } \\
\text { are currently active. }\end{array}$ \\
\hline Various scientific observations & 666 & USGS & $\begin{array}{l}\text { Wells included within the USGS NWIS database with at least one } \\
\text { observation after 1963. Excludes wells within the cooperative } \\
\text { network. }\end{array}$ \\
\hline Irrigation, commerical, industrial & 29 & SDDENR & Irrigation, commerical, and industrial-use water-supply wells. \\
\hline Minor-use water supply & 619 & SDDENR & Domestic and livestock water-supply wells. \\
\hline Geologic test hole & 1,907 & SDDENR & $\begin{array}{l}\text { Test holes to define physical and chemical properties of bedrock and } \\
\text { aquifers. }\end{array}$ \\
\hline Regional ground-water observations & 39 & SDDENR, USGS & $\begin{array}{l}\text { Cooperative network of ground-water-level observation wells. Some } \\
\text { wells are cooperative with USGS and SDDENR. Wells have at } \\
\text { least one measurment annually. }\end{array}$ \\
\hline Various scientific observations & 799 & USGS & $\begin{array}{l}\text { Wells included within the USGS NWIS database with at least one } \\
\text { observation after 1963. Excludes wells within the cooperative } \\
\text { network. }\end{array}$ \\
\hline
\end{tabular}

are shown in figure 9. Values for the coefficients and exponents associated with the at-a-station relations for each streamflow-gaging station, using the models of equations 1 through 3 (see Background section of report), are given in table 12. Although the coefficients $(a, c, k)$ for each relation generally are associated with local physical setting, sediment, and vegetation conditions, the exponents $(b, f, m)$ describe the rate at which each of the variables (width, depth, and velocity, respectively) adjust to changing discharges (Knighton, 1998). The exponents are the most widely scrutinized of published values (Park, 1977). Exponent values reported for streams of the midwestern United States by Leopold and Maddock (1953) average $0.26(b), 0.40(f)$, and $0.34(m)$ for width, depth, and velocity, respectively.

Width exponents of at-a-station hydraulic-geometry relations among selected gages of the Niobrara River average 0.14 , but range between 0.00 and 0.32 . Depth exponents average 0.40 and range from 0.31 to 0.46 . Velocity exponents average 0.45 and range between 0.34 and 0.57 . The average at-a-station exponent values indicate that at the local scale, the Niobrara River adjusts to changing discharges mainly through variation in flow depth and velocity. These data are in general agreement with an analysis by Buchanan (1981), which indicated that the stage of the lower Niobrara River did not increase proportionally to increases in discharge, but rather discharge was accommodated through increases in velocity by coincident decreases in channel-boundary roughness.

The at-a-station hydraulic geometry velocity exponent values have a wide range, and the average value of 0.45 is affected by the narrow reaches near the Mariaville, Verdel (1963-1985 water years), Sparks, and Cody streamflowgaging stations. Whereas Mariaville and Verdel likely are not representative of their adjacent river reaches because of their locations near channel constrictions, Cody and Sparks are similar to many of their surrounding reaches. These findings indicate that the at-a-station velocity exponent average may be skewed high, but the range is within the natural variation of the Niobrara River.

Coefficients of determination for hydraulic geometry relations indicate that between zero and 80 percent of the variance in width, depth, or velocity can be explained by discharge. The lowest coefficients of determination were all associated with the variance in channel width, further indicating a relatively weak relation between discharge and wetted- 


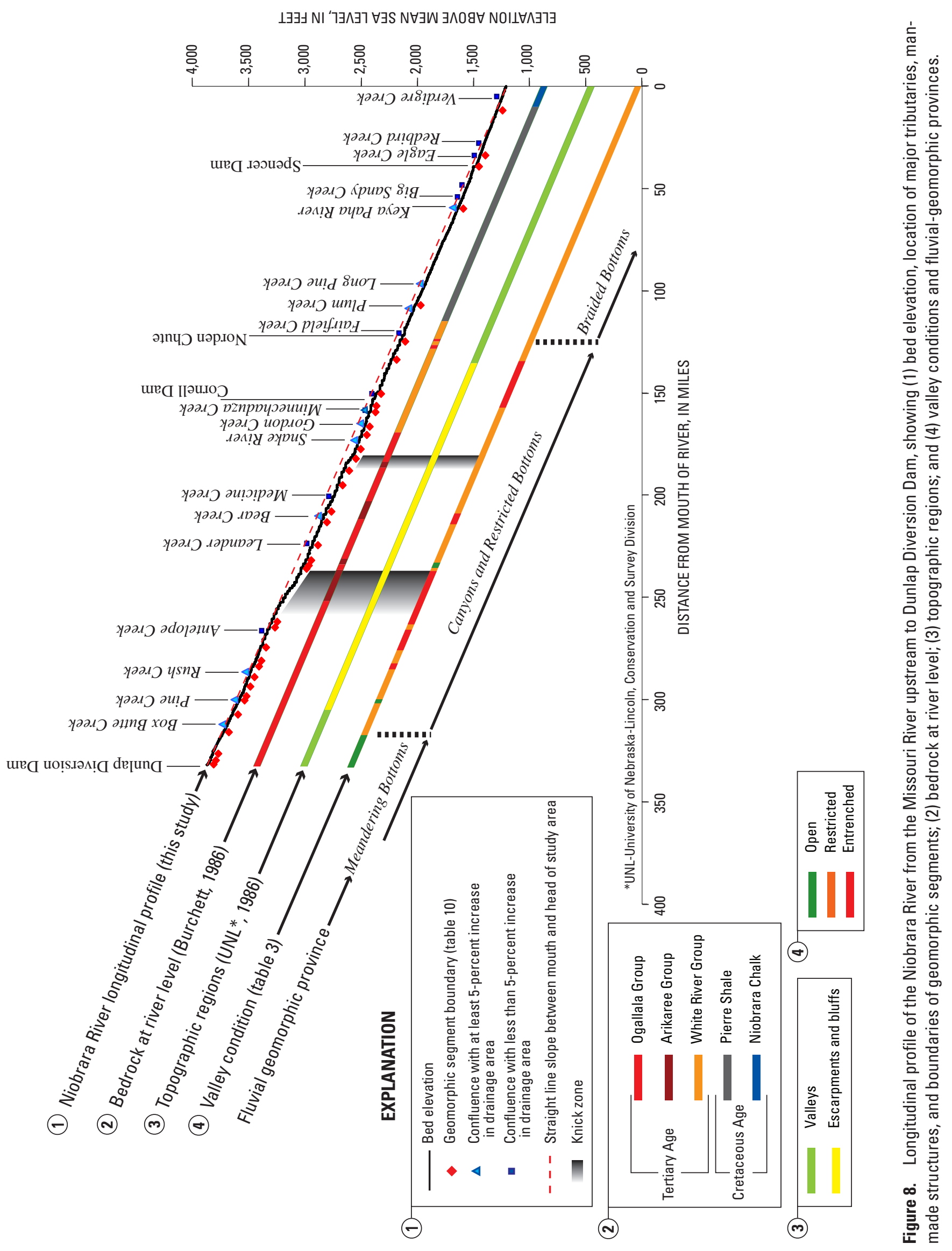


Table 10. Geomorphic segments of the Niobrara River between Dunlap Diversion Dam and the Missouri River, Nebraska.

[no., number; River mile, miles upstream from the Missouri River; S.A., percent of total length of Niobrara mainstem channel in study area; condition classes A through D refer to the channel degree of confinement, planview pattern, width variation, and bar configuration, respectively, as described in the geomorphic classification system included in table 3; "Mode" refers to the most frequently occuring condition among segments; "Per unit length" refers to the condition that is most frequent when considering total channel length within the study area]

\begin{tabular}{|c|c|c|c|c|c|c|c|c|}
\hline \multirow[b]{2}{*}{ Segment no. } & \multirow[b]{2}{*}{ River mile } & \multirow[b]{2}{*}{$\begin{array}{l}\text { Percent of } \\
\text { S.A. }\end{array}$} & \multicolumn{4}{|c|}{ Descriptive elements and assigned condition classes } & \multirow{2}{*}{$\begin{array}{l}\text { No. of bridges } \\
\text { within } \\
\text { segment }\end{array}$} & \multirow{2}{*}{$\begin{array}{c}\text { Segment } \\
\text { average } \\
\text { channel slope } \\
\text { (percent) }\end{array}$} \\
\hline & & & A & B & C & D & & \\
\hline \multicolumn{9}{|c|}{ Braided bottoms } \\
\hline 1 & 12 & 3.6 & 3 & 2 & 3 & 4 & 2 & 0.13 \\
\hline 2 & 34 & 6.6 & 3 & 2 & 3 & 3 & 2 & .13 \\
\hline 3 & 39 & 1.6 & 3 & 2 & 2 & 1 & 0 & .11 \\
\hline${ }^{14}$ & 60 & 6.2 & 3 & 2 & 3 & 4 & 1 & .13 \\
\hline 5 & 107 & 14.2 & 3 & 2 & 3 & 3 & 2 & .15 \\
\hline 6 & 125 & 5.4 & 2 & 2 & 3 & 3 & 4 & .15 \\
\hline \multicolumn{9}{|c|}{ Canyons and restricted bottoms } \\
\hline 7 & 134 & 2.7 & 2 & 2 & 1 & 2 & 1 & .16 \\
\hline 8 & 150 & 5.0 & 1 & 2 & 1 & 2 & 5 & .14 \\
\hline 19 & 156 & 1.8 & 1 & 2 & 2 & 3 & 2 & .13 \\
\hline 10 & 159 & .9 & 3 & 2 & 2 & 3 & 1 & .05 \\
\hline 11 & 166 & 2.1 & 3 & 2 & 2 & 1 & 1 & .14 \\
\hline 12 & 171 & 1.2 & 3 & 2 & 3 & 3 & 0 & .12 \\
\hline 13 & 178 & 2.1 & 2 & 2 & 2 & 1 & 1 & .15 \\
\hline 14 & 182 & 1.4 & 3 & 2 & 2 & 1 & 2 & .17 \\
\hline 15 & 188 & 1.8 & 2 & 2 & 2 & 1 & 2 & .20 \\
\hline 16 & 195 & 2.1 & 3 & 2 & 2 & 1 & 1 & .15 \\
\hline 17 & 208 & 3.9 & 2 & 2 & 2 & 1 & 3 & .15 \\
\hline 18 & 213 & 1.6 & 1 & 2 & 2 & 1 & 0 & .15 \\
\hline 19 & 224 & 3.4 & 3 & 2 & 3 & 3 & 2 & .13 \\
\hline 20 & 232 & 2.2 & 2 & 2 & 2 & 1 & 1 & .15 \\
\hline 21 & 234 & .8 & 4 & 3 & 1 & 2 & 1 & .15 \\
\hline 22 & 236 & .4 & 3 & 2 & 1 & 2 & 1 & .25 \\
\hline 23 & 262 & 7.8 & 1 & 3 & 1 & 2 & 1 & .19 \\
\hline 24 & 265 & .8 & 3 & 2 & 2 & 1 & 0 & .14 \\
\hline 25 & 275 & 3.0 & 1 & 2 & 3 & 3 & 2 & .15 \\
\hline 26 & 281 & 1.9 & 3 & 2 & 2 & 1 & 2 & .12 \\
\hline 27 & 284 & .8 & 1 & 2 & 3 & 1 & 0 & .14 \\
\hline 28 & 289 & 1.6 & 3 & 2 & 2 & 1 & 1 & .14 \\
\hline 29 & 294 & 1.4 & 2 & 2 & 2 & 1 & 1 & .15 \\
\hline 30 & 298 & 1.4 & 3 & 2 & 2 & 1 & 1 & .14 \\
\hline 31 & 300 & .6 & 4 & 2 & 2 & 1 & 1 & .15 \\
\hline 32 & 307 & 2.1 & 3 & 2 & 2 & 2 & 2 & .16 \\
\hline 33 & 316 & 2.6 & 2 & 2 & 1 & 2 & 3 & .18 \\
\hline \multicolumn{9}{|c|}{ Meandering bottoms } \\
\hline 34 & 326 & 3.2 & 4 & 2 & 1 & 2 & 1 & .17 \\
\hline 35 & 330 & 1.0 & 4 & 3 & 1 & 2 & 0 & .13 \\
\hline 36 & 332 & .6 & 4 & 2 & 1 & 2 & 0 & .20 \\
\hline \multicolumn{9}{|c|}{ Mode } \\
\hline & & & 3 & 2 & 2 & 1 & & \\
\hline \multicolumn{9}{|c|}{ Per unit length } \\
\hline & & & 3 & 2 & 3 & 3 & & \\
\hline
\end{tabular}

${ }^{1}$ Reach includes backwater of main channel dam. 
Table 11. Summary of longitudinal channel slopes in fluvial geomorphic provinces of the Niobrara River, Nebraska.

[n, number of geomorphic segments within province; S.D., standard deviation of segment slopes; max., maximum; min., minimum]

\begin{tabular}{|c|c|c|c|c|c|c|c|}
\hline \multirow[b]{2}{*}{$\begin{array}{l}\text { Fluvial geomorphic province } \\
\text { (fig. 8) }\end{array}$} & \multirow{2}{*}{$\begin{array}{l}\text { Province } \\
\text { mean slope, } \\
\text { in percent }{ }^{1}\end{array}$} & \multicolumn{6}{|c|}{ Summary of segments by province } \\
\hline & & $\mathbf{n}$ & $\begin{array}{l}\text { Mean slope, } \\
\text { in percent }^{2}\end{array}$ & $\begin{array}{l}\text { Slope S.D., } \\
\text { in percent }\end{array}$ & $\begin{array}{l}\text { Median slope, } \\
\text { in percent }\end{array}$ & $\begin{array}{l}\text { Max. slope, } \\
\text { in percent }\end{array}$ & $\begin{array}{l}\text { Min. slope, } \\
\text { in percent }\end{array}$ \\
\hline Meandering bottoms & 0.17 & 3 & 0.16 & 0.04 & 0.17 & 0.20 & 0.13 \\
\hline Canyons and restricted bottoms ${ }^{3}$ & .15 & 27 & .15 & .03 & .15 & .25 & .05 \\
\hline Braided bottoms ${ }^{3}$ & .14 & 6 & .13 & .01 & .13 & .15 & .11 \\
\hline Total study area ${ }^{3}$ & .15 & 36 & .15 & .03 & .15 & .25 & .05 \\
\hline $\begin{array}{l}{ }^{1} \text { Mean slope of fluvial geomorphic } \\
\text { province. }\end{array}$ & rovince compute & differe & between upstre & and downstre & m elevations divide & by along-chanr & length of the \\
\hline
\end{tabular}

channel width at the local scale. The probability $(p)$ values for slope-coefficient significance indicate that all but two of the calculated at-a-station power models have regression slopes that are significantly different from zero at the 90 -percent confidence level, and most models are highly significant (table 12). The hydraulic-geometry relations between width and discharge at the Mariaville gage and original site of the Verdel gage have power coefficients of nearly zero, indicating that channel-top width is virtually invariant over a range of discharges. Both of these gages were located at bridge reaches in which the channel narrowed significantly before passing under the bridge deck.

At one streamflow-gaging station only, Niobrara River near Gordon, did the at-a-station hydraulic-geometry coefficients and exponents have products and sums that varied from unity by more than 0.05 . This lack of compliance with continuity likely is the result of measurements being made at several different cross sections, a problem that could not be resolved because many of the original hydrographer's measurement notes were not available at the time of publication. Additionally, the median of discharges among measurement notes was 114 cubic feet per second $\left(\mathrm{ft}^{3} / \mathrm{s}\right)$, and more than 98 percent of the discharges measured by technicians were less than $300 \mathrm{ft}^{3} / \mathrm{s}$, but the range of measurements meeting the filter criteria includes values up to $1,380 \mathrm{ft}^{3} / \mathrm{s}$. Thus, in addition to the problem of measurement location, there are too few measurements at high-magnitude flows to represent the natural hydraulic variation; therefore, coefficient and exponent values may be skewed.

\section{Downstream Hydraulic Geometry of Niobrara River}

Downstream hydraulic-geometry relations for the study area indicate that the Niobrara River adjusts its geometry to gains in drainage area and discharge mainly through increases in channel width. This is indicated by the exponents of the width relation, which are more than double the magnitude of depth and velocity exponents for all flow conditions analyzed (table 13). The width exponents in the study area are only slightly higher than the most commonly cited value of 0.5 for alluvial rivers (Parker and others, 2007). Downstream hydraulic-geometry relations agree with geomorphic segmentation data, which described a river that increases in width, and width variation downstream from the contact between Tertiary and Cretaceous bedrock units. Downstream hydraulic geometry data also are in general agreement with an analysis performed by Buchanan (1981), which determined that the Niobrara River channel decreased in width after installation of Merritt Reservoir on the Snake River reduced mean monthly flows. Coefficients of determination for hydraulic geometry models indicate that between 61 and 79 percent of the variance in downstream geometry is explained by increasing discharge. All downstream hydraulic geometry regression models have slope coefficients that are significantly different from zero at the 90-percent confidence level. In addition, the products of coefficients and sums of model exponents are all within 0.05 of unity, indicating the relations conform with continuity.

The graphical summaries of downstream hydraulicgeometry relations over a range of flow frequencies are shown in figure 10. The wide scatter in hydraulic geometry values for higher-magnitude discharges indicates that geometry in the most downstream reaches of the Niobrara has a large degree of variability. Although this result is in general agreement with the geomorphic segmentation data for the lower Niobrara (table 10), the large degree of width variation also is the consequence of site selection for streamflow-gaging stations. Whereas much of the lower Niobrara is characterized by a wide, braided channel, streamflow-gaging stations generally are located at natural or engineered channel constrictions. As mentioned above, the Niobrara channel near the Mariaville and Verdel (for 1963-1985 period of record) streamflowgaging stations is much narrower than reaches immediately upstream and downstream. The Niobrara River near Norden is located at a bedrock constriction that is, again, much narrower than nearby upstream and downstream channel environments. The Niobrara River near Spencer streamflow gage is located on a single-thalweg channel with alternate bars, a condition that likely results from the local sediment and hydrologic regimes regulated by the upstream dam. 

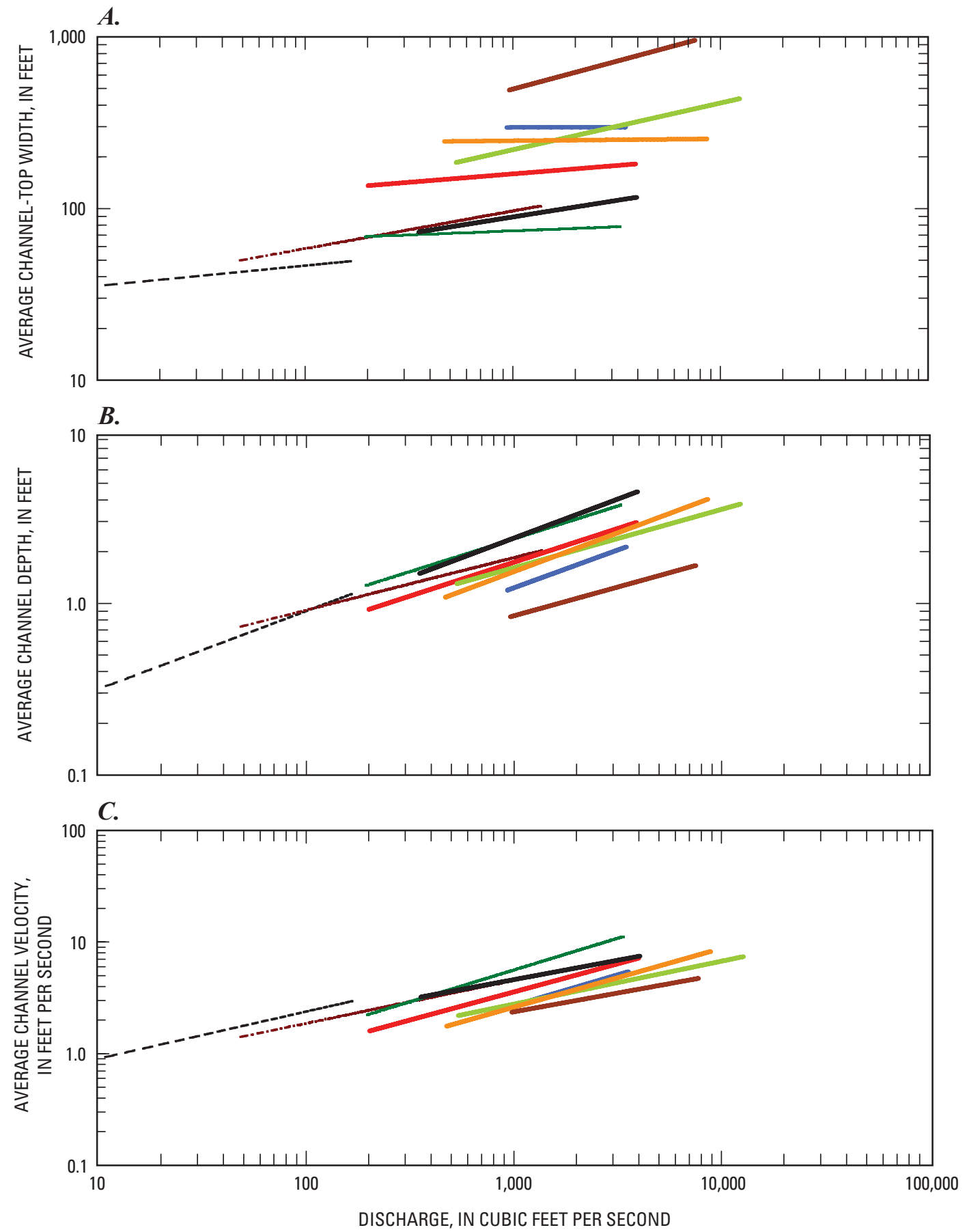

EXPLANATION

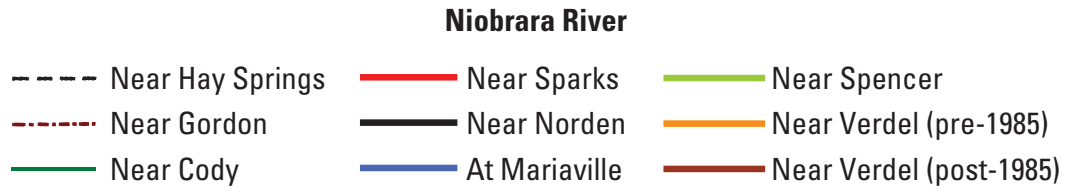

Figure 9. At-a-station hydraulic geometry relations for selected streamflow-gaging stations on the Niobrara River, showing relations between discharge and $(A)$ channel width; $(B)$ average cross-sectional depth; and $(C$ ) average flow velocity. (All records used in the analysis are from post-1963 period except those stations near Hay Springs and Cody, which are upstream from the Snake River confluence). 
Table 12. At-a-station hydraulic geometry relations for selected Niobrara River streamflow-gaging stations.

[Period of record for each streamflow-gaging station expressed in water years; period of record used for hydraulic geometry analysis may differ from total available period of record for streamflow gage listed; $a$, width coefficient; $b$, width exponent; $c$, depth coefficient; $f$, depth exponent; $k$, velocity coefficient; $m$, velocity exponent; $\mathrm{ft}^{3} / \mathrm{s}$, cubic feet per second; --, not applicable]

\begin{tabular}{|c|c|c|c|c|c|c|c|c|c|c|}
\hline \multirow[b]{2}{*}{$\begin{array}{l}\text { Parameter } \\
\text { or statistic }\end{array}$} & \multicolumn{10}{|c|}{ Station name, number, and period of record ${ }^{1}$} \\
\hline & $\begin{array}{c}\text { Niobrara } \\
\text { River near } \\
\text { Hay } \\
\text { Springs, } \\
06456500 \text {, } \\
1951-63^{1}\end{array}$ & $\begin{array}{c}\text { Niobrara } \\
\text { River near } \\
\text { Gordon, } \\
06457500 \text {, } \\
1964-90\end{array}$ & $\begin{array}{c}\text { Niobrara } \\
\text { River near } \\
\text { Cody, } \\
\text { 06459000, } \\
1949-56\end{array}$ & $\begin{array}{c}\text { Niobrara } \\
\text { River near } \\
\text { Sparks, } \\
06461500, \\
1964-2007\end{array}$ & $\begin{array}{c}\text { Niobrara } \\
\text { River near } \\
\text { Norden, } \\
06462000 \text {, } \\
1964-83\end{array}$ & $\begin{array}{c}\text { Niobrara } \\
\text { River near } \\
\text { Mariaville, } \\
06463720 \text {, } \\
1986-90\end{array}$ & $\begin{array}{c}\text { Niobrara } \\
\text { River near } \\
\text { Spencer, } \\
\text { 06465000, } \\
\text { 1964-2000 }\end{array}$ & $\begin{array}{l}\text { Niobrara } \\
\text { River near } \\
\text { Verdel }^{2} \\
06465500 \text {, } \\
1964-85\end{array}$ & $\begin{array}{c}\text { Niobrara } \\
\text { River near } \\
\text { Verdel }^{2} \\
\text { 06465500, } \\
\text { 1986-2007 }\end{array}$ & $\begin{array}{c}\text { Average of } \\
\text { nine } \\
\text { stations }\end{array}$ \\
\hline & 35 & 589 & 142 & 485 & 196 & 34 & 331 & 238 & 117 & 241 \\
\hline \multicolumn{11}{|c|}{ Maximum discharge of included measurements, in $\mathrm{ft}^{3} / \mathrm{s}$} \\
\hline & 168 & 1,380 & 3,340 & 3,940 & 3,990 & 3,520 & 12,500 & 8,680 & 7,610 & 5,014 \\
\hline \multicolumn{11}{|c|}{ Minimum discharge of included measurements, in $\mathrm{ft}^{3} / \mathrm{s}$} \\
\hline & 10 & 49 & 197 & 203 & 357 & 946 & 540 & 474 & 975 & 417 \\
\hline$b$ & .12 & .22 & .05 & .10 & .19 & .00 & .27 & .01 & .32 & .14 \\
\hline$p$ value ${ }^{4}$ & .05 & $<.0001$ & $<.0001$ & $<.0001$ & $<.0001$ & .82 & $<.0001$ & .14 & $<.0001$ & -- \\
\hline $\mathrm{COD}^{5}$ & .11 & .11 & .42 & .12 & .24 & .00 & .20 & .01 & .12 & -- \\
\hline \multicolumn{11}{|c|}{ Depth coefficients and exponents (equation 2) } \\
\hline$c$ & .11 & .22 & .17 & .11 & .10 & .06 & .15 & .07 & .08 & .12 \\
\hline$f$ & .46 & .31 & .39 & .40 & .46 & .44 & .34 & .46 & .34 & .40 \\
\hline$p$ value $^{4}$ & $<.0001$ & $<.0001$ & $<.0001$ & $<.0001$ & $<.0001$ & $<.0001$ & $<.0001$ & $<.0001$ & $<.0001$ & -- \\
\hline $\mathrm{COD}^{5}$ & .70 & .25 & .69 & .58 & .70 & .52 & .23 & .73 & .24 & -- \\
\hline \multicolumn{11}{|c|}{ Velocity coefficients and exponents (equation 3) } \\
\hline \multicolumn{11}{|c|}{ Sum of exponents } \\
\hline & 1.00 & .92 & 1.01 & 1.00 & 1.00 & 1.00 & 1.00 & 1.00 & 1.00 & .99 \\
\hline \multicolumn{11}{|c|}{${ }^{1}$ Measurement record for gage near Hay Springs was unavailable for water years 1956-1960. } \\
\hline \multicolumn{11}{|c|}{${ }^{3}$ Number of measurements used in hydraulic-geometry calculations (number retained after filter criteria were applied). } \\
\hline $\begin{array}{l}{ }^{4} \text { Probability } \\
\text { cance at the } 9\end{array}$ & $\begin{array}{l}(p \text { value) that } \\
\text {-percent confi }\end{array}$ & $\begin{array}{l}\text { regression slop } \\
\text { idence level. }\end{array}$ & oe is zero (no c & correlation betw & reen discharge & and geometric & c variable); valu & es less than 0.1 & 10 indicate mo & del signifi- \\
\hline
\end{tabular}



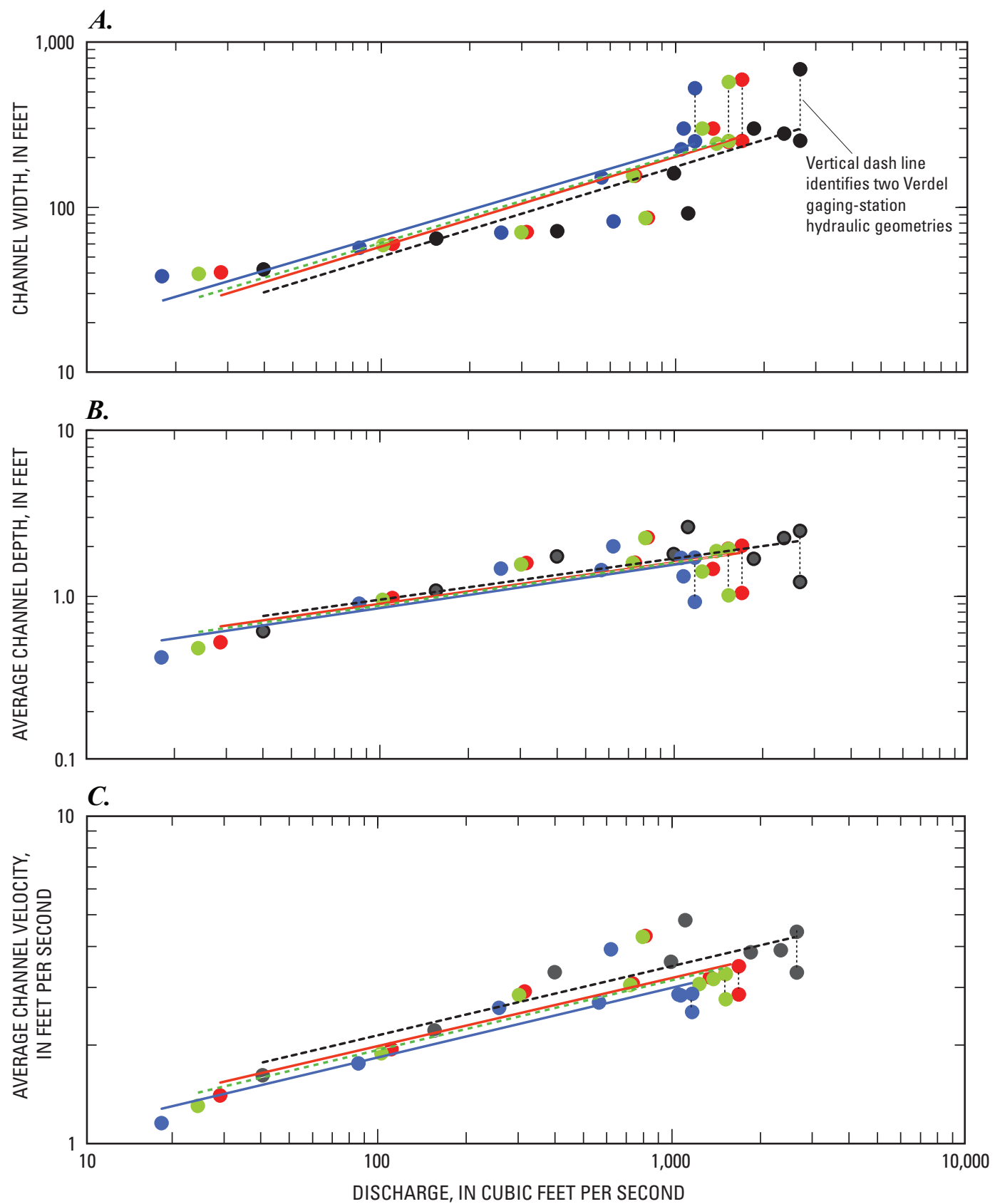

\section{EXPLANATION}

Streamflow condition

- Mean

Fitting line - Mean

- 10-percent exceedance

-... Fitting line - 10-percent exceedance

50-percent exceedance

- - - - Fitting line - 50-percent exceedance

- 75-percent exceedance

- Fitting line - 75-percent exceedance

Figure 10. Downstream hydraulic geometry relations for the Niobrara River between the streamflowgaging station near Hay Springs, Nebraska, and the streamflow-gaging station near Verdel, Nebraska, showing downstream relations between discharge and $(A)$ channel width; $(B)$ channel depth; and (C) flow velocity. (All records used in the analysis are from post-1963 period except those stations near Hay Springs and Cody, which are upstream from the Snake River confluence. Data include two different geometry values for the station near Verdel, which was at two different locations since 1963). 
Table 13. Downstream hydraulic geometry relations for the Niobrara River between Hay Springs and Verdel, Nebraska.

\begin{tabular}{|c|c|c|c|c|}
\hline \multirow{2}{*}{$\begin{array}{c}\text { Param- } \\
\text { eter or } \\
\text { statistic }\end{array}$} & \multirow{2}{*}{$\begin{array}{c}\text { Mean } \\
\text { annual } \\
\text { discharge }\end{array}$} & \multicolumn{3}{|c|}{ Flow exceedance ${ }^{1}$} \\
\hline & & $10 \%$ & $50 \%$ & $75 \%$ \\
\hline \multicolumn{5}{|c|}{ Maximum discharge used in regression model, in $\mathrm{ft}^{3} / \mathrm{s}$} \\
\hline & 1,708 & 2,695 & 1,540 & 1,180 \\
\hline \multicolumn{5}{|c|}{ Minimum discharge used in regression model, in $\mathrm{ft}^{3} / \mathrm{s}$} \\
\hline & 29 & 40 & 24 & 18 \\
\hline \multicolumn{5}{|c|}{ Width coefficients and exponents (equation 1) } \\
\hline$a$ & 4.72 & 4.08 & 5.29 & 5.95 \\
\hline$b$ & .54 & .54 & .53 & .52 \\
\hline$p$ value $^{2}$ & $<.001$ & $<.001$ & $<.001$ & $<.001$ \\
\hline $\mathrm{COD}^{3}$ & .76 & .77 & .75 & .75 \\
\hline \multicolumn{5}{|c|}{ Depth coefficients and exponents (equation 2) } \\
\hline$c$ & .28 & .29 & .26 & .25 \\
\hline$f$ & .25 & .25 & .26 & .26 \\
\hline$p$ value $^{2}$ & .01 & .01 & .01 & .01 \\
\hline $\mathrm{COD}^{3}$ & .61 & .62 & .63 & .63 \\
\hline \multicolumn{5}{|c|}{ Velocity coefficients and exponents (equation 3) } \\
\hline$k$ & .76 & .81 & .73 & .69 \\
\hline$m$ & .21 & .21 & .21 & .21 \\
\hline$p$ value $^{2}$ & $<.001$ & $<.001$ & $<.001$ & $<.001$ \\
\hline $\mathrm{COD}^{3}$ & .77 & .79 & .77 & .77 \\
\hline \multicolumn{5}{|c|}{ Product of coefficients } \\
\hline & .99 & .97 & 1.00 & 1.01 \\
\hline \multicolumn{5}{|c|}{ Sum of exponents } \\
\hline & 1.00 & 1.00 & 1.00 & 1.00 \\
\hline
\end{tabular}

${ }^{1}$ Refers to the percentage of days from period of record that flow exceeded a particular magnitude. See table 4 for values associated with a particular streamflow-gaging station; exceedance was calculated for each gaging station for its particular period of record and used to develop the data values to which hydraulic-geometry relations were fitted.

${ }^{2}$ Probability ( $p$ value) that regression slope is zero (no correlation between discharge and geometric variable); values less than 0.10 indicate model significance at the 90-percent confidence level.

${ }^{3}$ Coefficient of determination for least-squares estimate of regression equation.

The Niobrara River near Verdel (1986-2007 period) is the only station on the lower Niobrara River that has channel dimensions similar to those upstream and downstream, and is likely the station that most accurately represents channel adjustment processes in the wider, braided sections. The differences in adjustment processes are well illustrated when the two periods of record for the two different locations of the Verdel streamflow-gaging station are compared. For every exceedance frequency in figures $10 A-C$, there are two data points that have exactly the same discharge; these data points represent the geometries of the two different Verdel streamflow-gaging station locations. For all flow regimes, the channel is wider, shallower, and slower at the new (19862007 period) Verdel streamflow-gaging station relative to the old station location at the channel constriction. The disparity in width between the two stations increases for increasing discharge and is an artifact of the large differences in at-astation width exponents between locations. The effect of narrow channels at streamflow-gaging locations on downstream hydraulic-geometry relations, and differences between the Verdel at-a-station exponents, indicate that downstream hydraulic geometry width exponents actually may be skewed lower than those that would be computed from natural cross sections, and may not be accurately representing downstream adjustment processes of the Niobrara River.

\section{Hydraulic Microhabitat: An Example from the Niobrara River near Sparks, Nebraska}

Comparison of cross-section geometries, between lowerdecile, median-quantile, and upper-decile flows of the 1988 and 2003 measurements, indicates that the bed of the Niobrara River channel scours even with moderate increases in discharge (fig. 11A). The scouring is accompanied by increases in the magnitude and variability of velocities, especially between median-quantile and upper-decile flows (fig. 11B). Comparison of the distributions of depths and velocities between median-quantile and upper-decile flows indicates that the increase in velocity with increasing discharge is accompanied by only minor increases in channel depth. For example, visual examination of figure $11 B$ indicates that the depth distribution during the 1988 upper-decile flow was not altogether different from the depth distribution during the 2003 median-quantile flow. The velocity distribution of the 1988 upper-decile flow, however, was dominated by velocities that were at least 1 foot per second (ft/s) greater than the 2003 median-quantile flows (fig. 11B), confirming that velocity is the dominant mode of hydraulic adjustment. These analyses are in general agreement with the at-a-station hydraulic-geometry relations for the Niobrara River near Sparks, Nebr., which indicate that, at the local scale, velocity increase is the primary hydraulic adjustment to increased discharge (table 12). Bedform roughness changes are the physical mechanism associated with this hydraulic adjustment (Buchanan, 1981). Additionally, the magnitude of scour depth with increasing discharge is limited near the Sparks streamflow-gaging station because of the presence of shallow bedrock.

Analysis of hydraulic microhabitat types at the Sparks streamflow-gaging station indicates that combinations of water depth and velocity are variable with discharge and time. Measurements analyzed from 1988 indicate that the upper-decile discharge redistributed microhabitats by increasing the availability of deep-moderate and deep-swift microhabitat niches (figure 11C). Conversely, measurements analyzed from 2003 indicate that the median-quantile flow had similar microhabitat distributions to those of the 1988 upper-decile flow. The differences in microhabitat distributions between the median-quantile flows of 1988 and 2003 may be because of the slightly higher magnitude of flow in 2003, or differences in the amount of sand on bed. Shallow-slow, intermediate-slow, and intermediate-moderate microhabitat niches all show a decrease in 

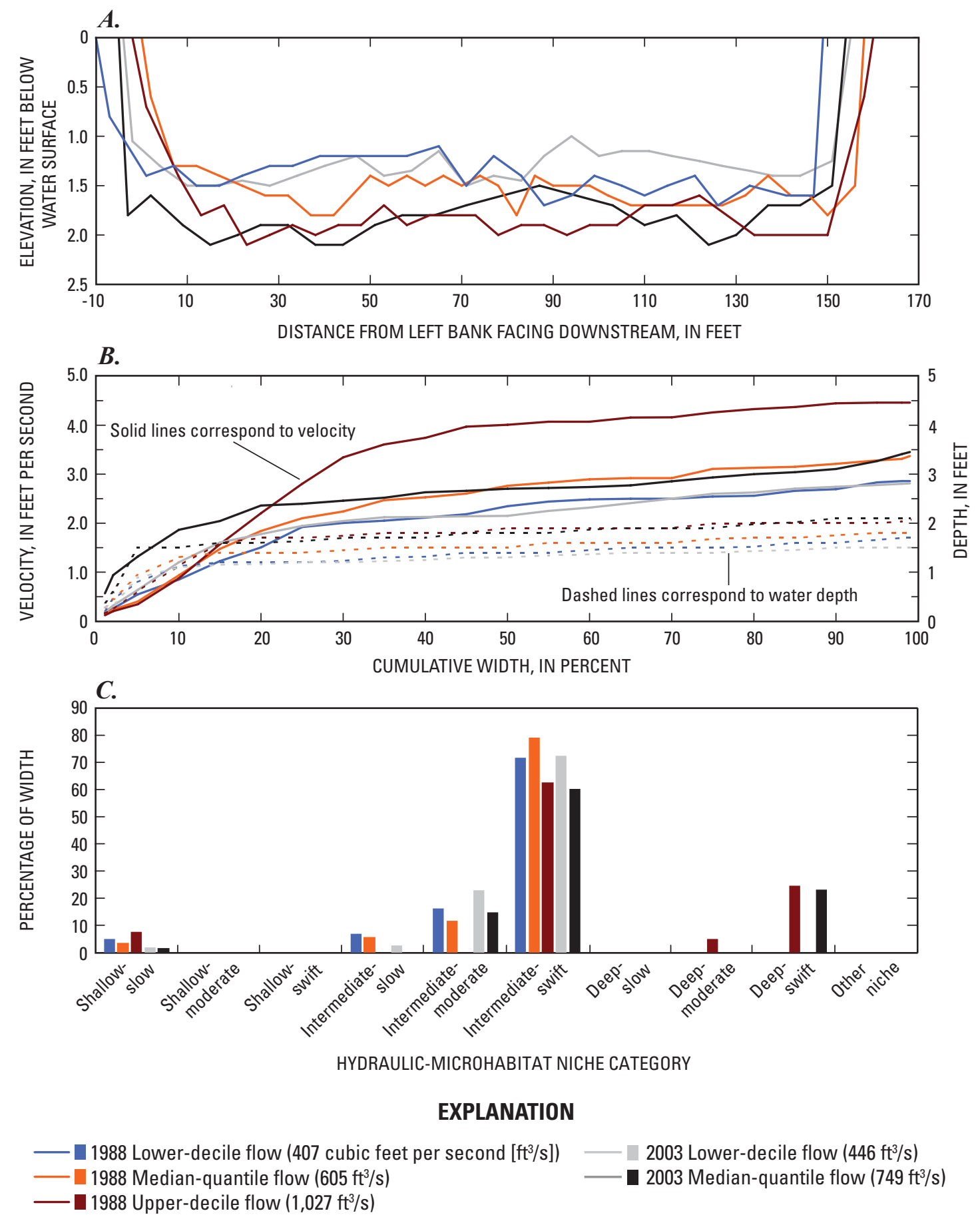

Figure 11. Channel geometry, velocity distribution, and microhabitat extent over a range of flow-exceedance frequencies for the Niobrara River near Sparks, Nebraska. (A) Cross-sectional form; (B) velocity and depth distributions; and $(C)$ hydraulic microhabitat distributions. (Hydraulic microhabitat classes are defined in table 5). 
extent from lower to median-quantile discharges. The creation of the deep-swift niche in 1988 and 2003 came mainly at the expense of the intermediate-moderate and intermediate-swift hydraulic microhabitat niches. These data indicate that higher median-quantile to upper-decile discharges are important for the creation of deeper hydraulic microhabitat niches.

Of the flows analyzed, the upper-decile flow of 1988 had the broadest range of hydraulic microhabitats, including the highest percentage of the shallow-slow niche, and the only occurrence of the deep-moderate niche. The increase in the extent of the shallow-slow microhabitat niche during the upper-decile discharge in 1988 could be because of a number of reasons: inundation of low-floodplains or shelves, prompting an increase in shallow and slow habitat; an increase in near-bank velocities prompting the technician to make a velocity measurement closer to the bank; or an increase in the affect of bank vegetation as stage rises, which may create slower, more turbulent hydraulic zones in their wake. Because the width of the channel did not change dramatically over the range of flows measured, the increase in the shallow-slow niche is likely because of the latter two possibilities.

Distributions of microhabitat classes at any given point in time are dependent on several factors, including the preceding hydrologic context, which may have persistent effects on channel geometry. Thus, habitat distributions are best viewed and compared in a broader temporal and hydrologic context before conclusions can be drawn (Ginting and Zelt, 2008). A more detailed analysis of inter-year, between year, and decadal comparison of changes in microhabitat likely would provide a better description of the temporal variability of microhabitats in the Niobrara River. Further, an analysis of microhabitat trends over short, drought periods may provide indications of the direction of microhabitat distributions from future water depletions.

\section{Summary and Conclusions}

An inventory and initial analysis of the hydrogeomorphic data and characteristics of the Niobrara River between Dunlap Diversion Dam in Dawes County, Nebr., and the Missouri River confluence was completed. The goal of the inventory was to provide an informational foundation for ongoing or future scientific investigations, and thus provided information over and above that which was necessary for the hydrogeomorphic analysis. The objective of the hydrogeomorphic analysis was to describe the Niobrara River channel and valley characteristics, divide the main channel into segments of differing potential physical habitat characteristics, and understand how the channel and physical habitats of the Niobrara River adjust to changing discharges.

The inventory of available hydrogeomorphic data indicates that many of the tributaries to the Niobrara River have at least some hydrologic data, which, at a minimum, include estimates of peak discharges in isolated years. In addition, several larger tributaries (tributaries that contribute at least an approximate 5-percent drainage area increase at their confluence) have water-quality data that include measurements of suspended sediment. Ground-water well spacing currently is too sparse for a relevant analysis of existing ground-water and surface-water interactions at the scale of a river segment.

Thirty-six geomorphic segments were identified and described along the Niobrara River in the study area using a customized classification system. Three geomorphic provinces were identified using natural boundaries within the geomorphic characteristics of the segments: an upper province characterized by open valleys and a sinuous, equiwidth channel; a central province characterized by mixed valley and channel settings, including several entrenched canyon reaches; and a lower province characterized by a wide, yet restricted, valley and a wide, persistently braided channel. The coincidence of channel slope perturbations and bedrock contacts indicates that channel slope, and consequent attributes of geomorphic segments of the Niobrara River in the study area, may largely be controlled by the properties of bedrock.

At-a-station hydraulic-geometry relations indicate that cross-sectional adjustments to changes in discharge are accommodated primarily by changes in flow velocity. Downstream hydraulic-geometry relations for eight streamflow-gaging stations along the main channel indicate that the Niobrara River in the study area adjusts its geometry to changing discharges primarily by changes in channel-top width. At-a-station and downstream hydraulic-geometry relations are in general agreement with previously published hydraulic- and channel-adjustment data. Downstream hydraulic-geometry relations also are in agreement with the geomorphic segmentation data, which describe a river that increases in width and width variation, especially downstream from the contact between Tertiary and Cretaceous bedrock units. Although the at-a-station hydraulic geometry values used to create the downstream hydraulic geometry relations represent the natural variation in channel width in the lower Niobrara River, the downstream width exponents $(m)$ are likely skewed low because the locations of many of the streamflow-gaging stations are at natural or engineered constrictions.

Analysis of hydraulic microhabitats at a gage within the National Scenic River reach of the Niobrara indicated that velocity changes are the primary adjustment in hydraulic-habitat characteristics over a range of discharges. Comparison of microhabitat distributions over a range of discharges indicates that shallow and intermediate hydraulic microhabitat niches are available over all flows, but deeper hydraulic niches are only available during higher median-quantile and upper-decile discharges. Comparison of microhabitat distributions at similar flow-exceedance frequencies separated by 15 years indicated that microhabitat is temporally variable, although the total scale of this variability was not captured by the initial analysis. A more detailed temporal analysis of hydraulic microhabitat, including analysis of drought periods, would likely provide a better description of the temporal variability of microhabitats and the potential direction of microhabitat changes caused by future water depletions. 


\section{Acknowledgments}

This report is one of several produced in cooperation with the Nebraska Game and Parks Commission to provide sound scientific information for managing the Niobrara River. The authors thank Larry Hutchinson and Richard Holland of the Nebraska Game and Parks Commission for their thoughtful questions, suggestions, and support of this project. Bethany Zelt volunteered numerous hours to enter stream dischargemeasurement data for the hydraulic-geometry analysis.

\section{References Cited}

Baxter, C.V., and Hauer, F.R., 2000, Geomorphology, hyporheic exchange, and selection of spawning habitat by bull trout (Salvelinus confluentus): Canadian Journal of Fisheries and Aquatic Science, v. 57, p. 1,470-1,481.

Bentall, R., and Shaffer, F.B., 1979, Availability and use of water in Nebraska, 1975: Lincoln, University of Nebraska, Conservation Survey Division, Nebraska Water Survey Paper 48, $121 \mathrm{p}$.

Bentall, R., 1991, Facts and figures about Nebraska rivers: Lincoln, University of Nebraska, Conservation and Survey Division, Water Supply Paper No. 73, 16 p.

Bramblett, R.G., and White, R.G., 2001, Habitat use and movements of pallid and shovelnose sturgeon in the Yellowstone and Missouri Rivers in Montana and North Dakota: Transactions of the American Fisheries Society, v. 130, p. $1,006-1,025$.

Brice, J.C., and Blodgett, J.C., 1978, Countermeasures for hydraulic problems at bridges: Federal Highway Administration Report No. FHWA-RD-78-162, v. 1, 169 p.

Bridge, J.S., 2003, Rivers and floodplains-forms, processes, and sedimentary record: Oxford, England, Blackwell Publishing, $491 \mathrm{p}$.

Buchanan, J.P., 1981, Channel morphology and sedimentary facies of the Niobrara River, north-central Nebraska: Fort Collins, Colo., Colorado State University, M.S. Thesis, $126 \mathrm{p}$.

Burchett, R.R., comp., 1986, Geologic bedrock map of Nebraska: Lincoln, Nebraska Geological Survey, scale $1: 1,000,000$.

Chen, A.H., Rus, D.L., and Stanton, C.P., 1999, Trends in channel gradation in Nebraska streams, 1913-95: U.S. Geological Survey Water-Resources Investigations Report 99-4103, 29 p.
Cole, J.M., 1996, Aggradation, degradation, and levels of heterogeneity of the braided Niobrara River, Nebraska: Fort Collins, Colo., Colorado State University, M.S. Thesis, $83 \mathrm{p}$.

Condra, G.E., and Reed, E.C., 1943, The Geological Section of Nebraska: Nebraska Geological Survey Bulletin No. 14, $82 \mathrm{p}$.

Dappen, P., Merchant, J., Ratcliffe, I., and Robbins, C., 2007, Delineation of 2005 land use patterns for the State of Nebraska Department of Natural Resources: Lincoln, Nebr., University of Nebraska, Center for Advanced Land Management Information Technologies, $80 \mathrm{p}$.

Dietsch, B.J., 2007, Water-quality and fish-community data for the Niobrara National Scenic River, Nebraska: U.S. Geological Survey Fact Sheet 2007-3098, 6 p.

Doyle, M.W., Stanley, E.H., Strayer, D.L., Jacobson, R.B., and Schmidt, J.C., 2005, Effective discharge analysis of ecological processes in streams: Water Resources Research, v. 41, $16 \mathrm{p}$.

Elliot, C.M., and Jacobson, R.B., 2006, Geomorphic classification and assessment of channel dynamics in the Missouri National Recreation River, South Dakota and Nebraska: U.S. Geological Survey Scientific Investigations Report 2006-5313, 66 p.

Eschner, T.R., 1983, Hydraulic geometry of the Platte River near Overton, south-central Nebraska: U.S. Geological Survey Professional Paper 1277-C, 27 p.

Etheridge, F.G., Skelly, R.L., and Bristow, C.S., 1999, Avulsion and crevassing in the sandy, braided Niobrara River-Complex response to base-level rise and aggradation: Special Publication of the International Association of Sedimentology, v. 28, p. 179-191.

Frissell, C.A., Liss, W.J., Warren, C.E., and Hurley, M.D., 1986, A hierarchical framework for stream habitat classification-Viewing streams in a watershed context: Environmental Management, v. 10, p. 199-214.

Ginting, D., and Zelt, R.B., 2008, Temporal differences in flow depth and velocity distributions and hydraulic microhabitats near bridges of the lower Platte River, Nebraska, 1934-2006: U.S. Geological Survey Scientific Investigations Report 2008-5054, 99 p.

Grams, P.E., and Schmidt, J.C., 1999, Geomorphology of the Green River in the eastern Uinta Mountains, Dinosaur National Monument, Colorado and Utah, in Miller, A.J., and Gupta, Avijit, Varieties of fluvial form: New York, John Wiley and Sons, p. 81-111.

Gran, K., and Paola, C., 2001, Riparian vegetation controls on braided stream dynamics: Water Resources Research, v. 37, p. $3,275-3,283$. 
Hanks, T.C., and Webb, R.H., 2006, Effects of tributary debris on the longitudinal profile of the Colorado River in Grand Canyon: Journal of Geophysical Research, v. 11, 13 p.

Hearty, P.J., 1978, The biogeography and geomorphology of the Niobrara River Valley near Valentine, Nebraska: Omaha, University of Nebraska, M.S. Thesis, 108 p.

Huang, H.Q., and Nanson, G.C., 2000, Hydraulic geometry and maximum flow efficiency as products of the principle of least action: Earth Surface Processes and Landforms, v. 25, p. $1-16$.

Hupp, C.R., and Osterkamp, W.R., 1996, Riparian vegetation and fluvial geomorphic processes: Geomorphology, v. 14, p. $277-295$.

Insightful Corporation, 2005, S-Plus 7 for Windows-users guide: Seattle, Wash., 80 p.

Interagency Wild and Scenic Rivers Council, 2008, National Wild and Scenic Rivers System - Niobrara River, Nebraska: accessed November 21, 2008, at http://www.rivers.gov/wsr-niobrara.htm

Johnsgard, P.A., 2001, The nature of Nebraska-ecology and biodiversity: Lincoln, Nebr., University of Nebraska Press, $402 \mathrm{p}$.

Jowett, I.G., 1997, Instream flow methods - a comparison of approaches: Regulated Rivers - Research and Management, v. 13 , p. $115-127$.

Junk, W.J., Bayley, P.B., and Sparks, R.E., 1989, The flood pulse concept in river-floodplain systems: Canadian Special Publication of Fisheries and Aquatic Science., v. 106, p. 110-127.

Juracek, K.E., and Fitzpatrick, F.A., 2003, Limitations and implications of stream classification: Journal of the American Water Resources Association, v. 39, p. 659-670.

Juracek, K.E., and Fitzpatrick, F.A., 2008, Geomorphic applications of stream-gage information: River Research and Applications - internet publication, doi: 10.1002/rra.1163.

Kennedy, E.J., 1983, Computation of continuous records of streamflow: U.S. Geological Survey Techniques of WaterResources Investigations 03-A13, 53 p.

Knighton, A.D., 1974, Variation in width-discharge relation and some implications for hydraulic geometry: Geological Society of America Bulletin, v. 85, p. 1,069-1,076.

Knighton, A.D., 1998, Fluvial forms and processes: Chichester, England, John Wiley and Sons, 383 p.

Kondolf, G.M., 1995, Geomorphological stream classification in aquatic habitat restoration - uses and limitations: Aquatic Conservation-Marine and Freshwater Ecosystems, v. 5, p. 127-141.
Kondolf, G.M., and Downs, P.W., 1996, Catchment approach to planning channel restoration, in Brookes, A., and Shields, F.D., Jr., River channel restoration-Guiding principles for sustainable projects: Chichester, England, John Wiley and Sons, p. 129-148.

Kondolf, G.M., Montgomery, D.R., Piegay, Herve, and Schmitt, Laurent, 2003, Geomorphic classification of rivers and streams, in Kondolf, G.E., and Piegay, H., eds., Tools in fluvial geomorphology: Chichester, John Wiley and Sons, p. 171-204.

Leopold, L.B., and Maddock, T., Jr., 1953, The hydraulic geometry of stream channels and some physiographic implications: U.S. Geological Survey Professional Paper 252, $57 \mathrm{p}$.

Leopold, L.B., and Wolman, M.G., 1957, River channel patterns; braided, meandering, and straight: U.S. Geological Survey Professional Paper 282-B, 85 p.

Maddock, I., 1999, The importance of physical habitat assessment for evaluating river health: Freshwater Biology, v. 41, p. 373-391.

McKenny, R., 1997, Formation and maintenance of hydraulic habitat units in streams of the Ozark Plateaus: University Park, Penn., Pennsylvania State University, State College, unpublished Ph.D. Dissertation, 340 p.

Montgomery, D.R., and Buffington, J.M., 1997, Channel-reach morphology in mountain drainage basins: Geological Society of America Bulletin, v. 109, p. 596-611.

Montgomery, D.R., and Gran, K.B., 2001, Downstream variations in the width of bedrock channels: Water Resources Research, v. 37, p. 1,841-1,846.

Naiman, R.J., Decamps, H., and Pollock, M., 1993, The role of riparian corridors in maintaining regional biodiversity: Ecological Applications, v. 3, p. 209-212.

Nebraska Department of Natural Resources, 2007, 2008 Annual evaluation of availability of hydrologically connected water supplies, determination of fully appropriatedfinal report: Lincoln, Nebraska Department of Natural Resources, $145 \mathrm{p}$.

Park, C.C., 1977, World-wide variations in hydraulic geometry exponents of stream channels - an analysis and some observations: Journal of Hydrology, v. 33, p. 133-146.

Parker, G., 1979, Hydraulic geometry of active gravel rivers: Journal of the Hydraulics Division, v. 109, p. 1,185-1,201.

Parker, G., Wilcock, P.R., Paola, C., Dietrich, W.E., and Pitlick, J., 2007, Physical basis for quasi-universal relations describing bankfull hydraulic geometry of single-thread gravel bed rivers: Journal of Geophysical Research, v. 112, $21 \mathrm{p}$. 
Peters, E.J., and Holland, R.S., 1992, Shallow-water fish community abundance and habitat use in the lower Platte River, Nebraska: University of Nebraska-Lincoln, Department of Forestry, Fisheries and Wildlife, Journal Series No. 9109.

Poff, N.L., Allen, J.D., Bain, M.B., Karr, J.R., Prestegaard, K.L., Richter, Brian, Sparks, R.E, and Stromberg, J.C., 1997, The natural flow regime - a new paradigm for riverine conservation and restoration: Bioscience, v. 47, p. 769-784.

Poff, N.L., and Ward, J.V., 1990, The physical habitat template of lotic systems - recovery in the context of historical pattern of spatio-temporal heterogeneity: Environmental Management, v. 14, p. 629-646.

Power, M.E., Sun, A., Parker, G., Dietrich, W.E., and Wooton, J.T., 1995, Hydraulic food chain models-An approach to the study of food-web dynamics in large rivers: Bioscience, v. 45 , p. $159-167$.

Rantz, S.E., and others, 1982, Measurement and computation of streamflow: U.S. Geological Survey Water Supply Paper 2175, v. 1, 284 p.

Resh, V.H., Brown, A.V., Covich, A.P., Gurtz, M.R., Li, H.W., Minshall, G.W., Reice, S.R., Sheldon, A.L., Wallace, J.B., and Wissmar, R.C., 1988, The role of disturbance in stream ecology: Journal of the North American Benthological Society, v. 7, p. 433-455.

Rhodes, D.D., 1977, The b-f-m diagram-graphical representation and interpretation of at-a-station hydraulic geometry: American Journal of Science, v. 277, p. 73-42.

Rosgen, D.L., 1994, A classification of natural rivers: Catena, v. 22, p. 169-199.

Schumm, S.A., 1963, A tentative classification of alluvial rivers: U.S. Geological Survey Circular 477, 10 p.

Schumm, S.A., 1985, Patterns of alluvial rivers: Annual Reviews in Earth and Planetary Sciences, v. 13, p. 5-27.

Scott, M.L., Friedman, J.M., and Auble, G.T., 1996, Fluvial processes and the establishment of bottomland trees: Geomorphology, v. 14, p. 327-339.

Shaffer, F.B., 1975, History of irrigation and characteristics of streamflow in northern Nebraska: U.S. Geological Survey Open-File Report 7501, 114 p.

Simon, A., and Castro, J., 2003, Measurement and analysis of alluvial channel form, in, Kondolf, G.E., and Piegay, H., eds., Tools in fluvial geomorphology: Chichester, John Wiley and Sons, p. 291-322.
Skelly, R.L., 1998, Evolution and facies architecture of modern braided river deposits-The Niobrara River, northeast Nebraska: Fort Collins, Colo., Colorado State University, M.S. Thesis, $239 \mathrm{p}$.

Soller, D.R., and Reheis, M.C., 2003, Surficial materials in the conterminous United States: United States Geological Survey Open-File Report 2003-275, map.

Stalnaker, C.B., Bovee, K.D., and Waddle, T.J., 1996, Importance of the temporal aspects of habitat hydraulics to fish population studies: Regulated Rivers-Research and Management, v. 12, p. 145-153.

Triska, F.J., Duff, J.H., and Avanzino, R.J., 1993, The role of water exchange between a stream channel and its hyporheic zone in nitrogen cycling at the terrestrial-aquatic interface: Hydrobiologia, v. 251, p. 167-184.

Turowski, J.M., Hovius, N., Wilson, A., and Horng, M.J., 2008, Hydraulic geometry, river sediment, and the definition of bedrock channels: Geomorphology, v. 99, p. 26-38.

U.S. Department of Agriculture, 2004, Farm Service AgencyAerial Photography Field Office, FSA Digital Orthophoto2003-UTM-Index for the State of Nebraska, Salt Lake City.

U.S. Department of Agriculture-Natural Resources Conservation Service, 2008, Watershed boundary dataset for HUC 101500, Nebraska: Natural Resources Conservation Service digital data, accessed online October 22, 2008 at http://datagateway.nrcs.usda.gov

University of Nebraska-Lincoln, Conservation and Survey Division, 1986, The ground water atlas of Nebraska: Lincoln, University of Nebraska, Conservation and Survey Division, Resource Atlas No. 4, 32 p.

Whittaker, D., and Shelby, B., 2008, Flows and recreation on the Niobrara National Scenic River, Nebraska-final report: Lincoln, Nebraska Game and Parks Commission, 27 p.

Wildhaber, M.L., Delonay, A.J., Papoulias, D.M., Galat, D.L., Jacobson, R.B., Simpkins, D.G., Braaten, P.J., Korschgen, C.E., and Mac, M.J., 2007, A conceptual life-history model for pallid and shovelnose sturgeon: U.S. Geological Survey Circular 1315, $18 \mathrm{p}$.

Williams, G.P., and Wolman, M.G., 1984, Downstream effects of dams on alluvial rivers: U.S. Geological Survey Professional Paper 1286, 83 p.

Wohl, E.E., and Merritt, D.M., 2001, Bedrock channel morphology: Geological Society of America Bulletin, v. 113, p. $1,205-1,212$.

Wolman, M.G., and Leopold, L.B., 1957, River flood plains: some observations on their formation: U.S. Geological Survey Professional Paper 282-C. 


\section{Appendixes}




\section{Appendix 1: Description of Niobrara River Streamflow-Gaging Stations}

\section{Appendix 1 Summary}

During the operational life of a streamflow-gaging station, the USGS maintains a running description of the location, establishment date, drainage area, types of gages used, elevation of reference datum and benchmarks, channel and hydraulic controls, environmental conditions, history, floods, and other miscellaneous information (Kennedy, 1983). After a streamflow gage is decommissioned, the description is finalized and archived. These descriptions serve to stratify measurement data if hydraulic conditions changed at a streamflow gage, or a gage was moved from one location to another. Excerpts of these descriptions are included in this report for Niobrara River streamflow-gaging stations used in the hydraulic-geometry analysis to set the context for the hydraulic-geometry relations. The descriptive excerpts have been paraphrased for clarity and consistency, and are presented below upstream to downstream for the Niobrara study area. The authors have included photos of the cross sections and bridges typically used for discharge measurement at the streamflow-gaging stations. Photos were unavailable for the streamflow-gaging station near Hay Springs, Nebr., and the streamflow-gaging station near Verdel for the 1963 to 1985 water years. The terms "left river bank" and "right river bank" refer to the direction of the river banks when a theoretical observer is in the middle of the river channel facing directly downstream.

\section{Niobrara River near Hay Springs}

The USGS maintained a streamflow-gaging station on the Niobrara River near Hay Springs, Nebr., from 1950 to 1964. The streamflow gage was located 14 mi south of Hay Springs and approximately $4 \mathrm{mi}$ upstream from Box Butte Creek. On July 31,1951 , the gage was moved $500 \mathrm{ft}$ downstream from its original location. For the period of record the Niobrara channel generally was shallow, with low, vegetated banks, a mild slope, and a sandy bottom. The channel was uniform directly upstream and downstream from a nearby bridge. Because of the mild slope and shallow depths, wading measurements were made for most flow conditions.

\section{Niobrara River near Gordon}

At a bridge crossing, located $11 \mathrm{mi}$ south of Gordon, Nebr., and approximately $16 \mathrm{mi}$ downstream from the Pine Creek confluence, the USGS and NDNR operated a streamflow-gaging station from 1946 to 1993 . The original streamflow gage was located 4 mi downstream from this location and operated intermittently between August 1928 and September 1932. Channel width varied considerably upstream and downstream from the bridge, but the channel itself was fairly straight and shallow. The streambed consisted of sand and silt and shifted considerably. The left bank was high and did not have a significant amount of vegetation. The right bank was low, covered in woody vegetation, and subject to overflow at higher magnitude discharges. Most measurements were made while wading. Only a few high-magnitude discharge measurements were made; these measurements were made from the bridge.

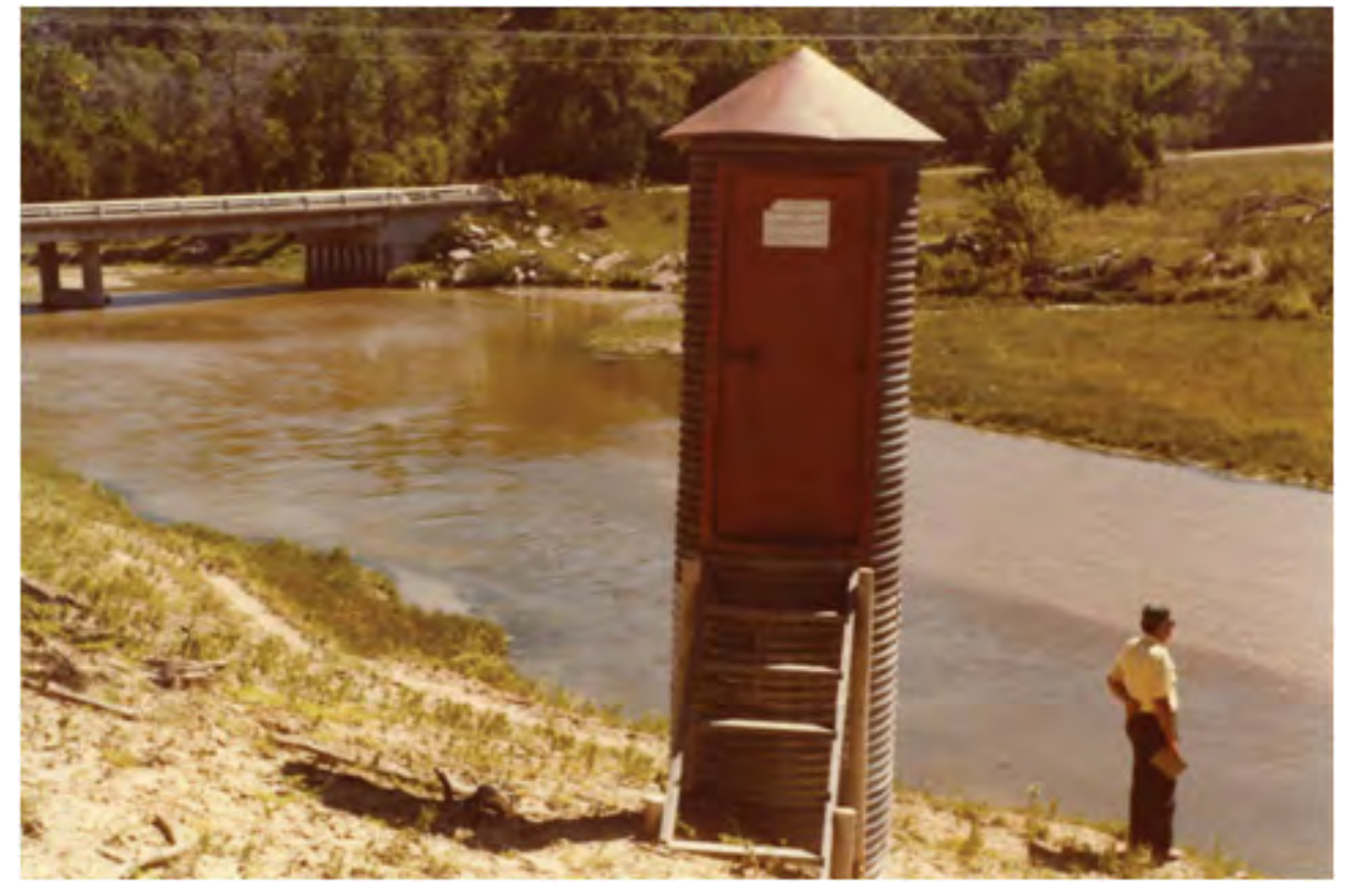

Figure 1-1. Photograph of the Niobrara River near Gordon streamflow-gaging station reach. Photograph was taken looking downstream. The gage house is in the foreground. Many of the measurements were made near the upstream face of the bridge. (USGS file photograph) 


\section{Niobrara River near Cody}

The USGS operated a streamflow gage $10 \mathrm{mi}$ south of Cody, Nebr., from 1948 to 1957, located 5 mi downstream from the Bear Creek confluence, and a quarter mile upstream from an unnamed county road bridge. The channel was straight and uniform $500 \mathrm{ft}$ upstream and downstream from the gage. The right bank was low and was overtopped during high-magnitude discharges, whereas the left bank was higher in elevation and rarely overtopped. The bed of the channel was gravel and the slope was steep enough to produce increased velocities during average flow conditions. A bedrock and gravel riffle extended from $50 \mathrm{ft}$ below the gage on the left bank to about $200 \mathrm{ft}$ below the gage on the right bank. The riffle was fairly persistent but subject to some shifting. During low flows the stream was waded, but during high-magnitude flows a cableway located $40 \mathrm{ft}$ downstream from the gage was used for measurements.

\section{Niobrara River near Sparks}

The Niobrara River near Sparks streamflow-gaging station is operated by the USGS, and is located within the National Scenic River reach approximately $5.5 \mathrm{mi}$ downstream from the Minnechaduza Creek confluence. The gage was established in October 1949 and presently is active. The right bank terminates at a high, forested bluff; the left bank has sparse vegetation. The banks are subject to overflow only during very high-magnitude discharges. The channel is shallow and straight with a mild slope. There is one thalweg only, but the location shifts occasionally. Most of the flows are measured by wading about $300 \mathrm{ft}$ downstream from the gage. High-magnitude discharge measurements can be made from a bridge located approximately 18 feet upstream from the gage.

\section{Niobrara River near Norden}

The USGS operated a streamflow-gaging station along the Niobrara River at a bridge approximately $1.5 \mathrm{mi}$ downstream from the Fairfield Creek confluence from 1953 to 1986. The gage was established in October 1952 and was discontinued temporarily in September 1983. The gage was reestablished in October 1985 and then discontinued again in September 1986. Although the streamflow gage was never moved, the original bridge crossing was washed out on May 28, 1962, and a new bridge was constructed $75 \mathrm{ft}$ upstream from the old bridge between March and May of 1963. The gage was located in a constricted section that has a steep bedrock bottom

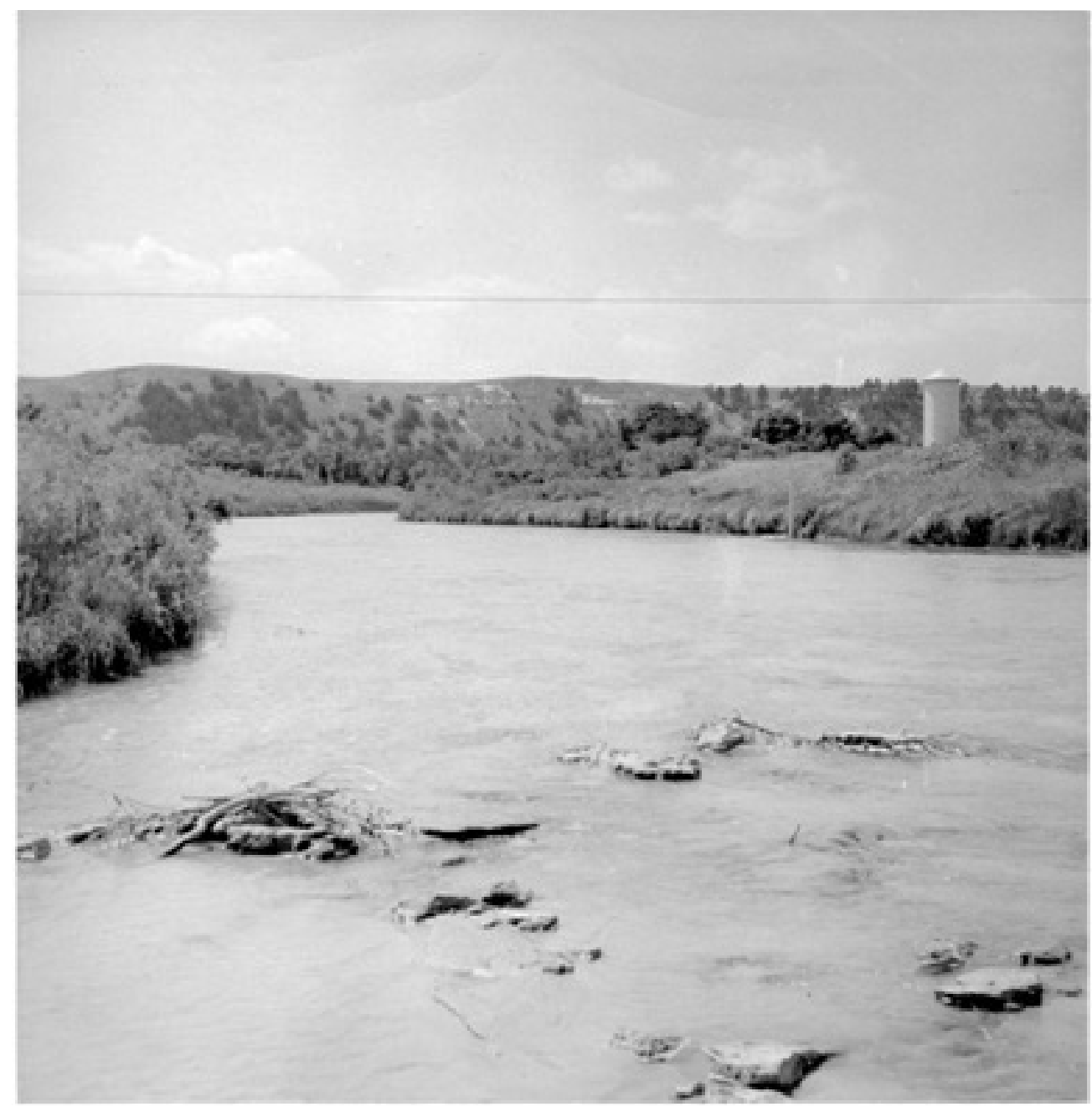

Figure 1-2. Photograph of the Niobrara River near Cody streamflow-gaging station reach. Photo was taken looking upstream. The gage house can be seen on the left river bank (right side of photo). The cableway can be seen one-third distance down from the top of the photo. Most measurements were made by wading underneath the cableway. High-flow measurements were made using the cable car. (USGS file photograph) 


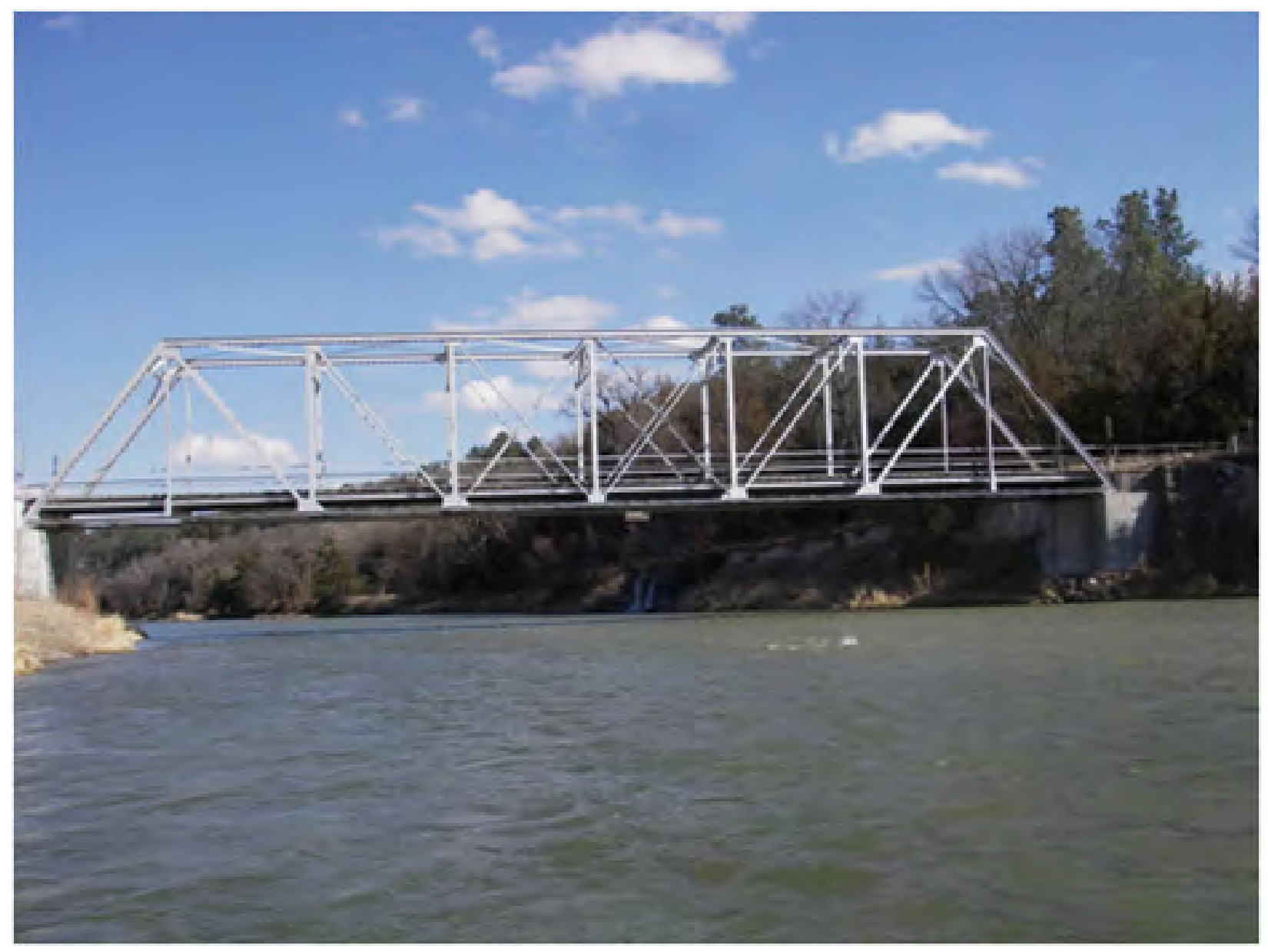

Figure 1-3. Photograph of the Niobrara River near Sparks streamflow-gaging station reach. Photo was taken looking downstream. The gage house is on the left bank, immediately downstream from the bridge. Most discharge measurements were made by wading downstream from the bridge. High-flow measurements are made from the bridge. (Photograph taken by Ronald Zelt, USGS).

composed of shale. The constricted section is slowly changing because of headward erosion of a knick point of the bed. Above the bedrock section there is a shifting layer of sand and gravel alluvium. The channel was straight from approximately $150 \mathrm{ft}$ upstream from the gage to approximately $400 \mathrm{ft}$ downstream from the gage. The right bank was steep, whereas the left bank was low with sparse woody vegetation. The channel was considerably wider upstream and downstream from the constriction where the streamflow gage was located. Most of the measurements were made at the bridge because of the depths and velocities in the constricted area, although some low-flow conditions allowed wading measurements.

\section{Niobrara River at Mariaville}

The USGS operated a streamflow-gaging station on the Niobrara River at a bridge approximately 17 mi downstream of the Long Pine Creek confluence and about $20.5 \mathrm{mi}$ upstream from the Keya Paha River confluence from water years 1986 to 1991 . The channel upstream and downstream from the bridge reach is extremely braided and approximately one-half mile wide. Within the bridge reach the channel is narrower, but subject to frequent shifting, and commonly flows in more than one thalweg. Both banks are fairly steep and vegetated. The bridge was used for high-magnitude discharge measurements, but because of the wide and shallow nature of the channel, wading measurements also were common.

\section{Niobrara River near Spencer}

The USGS operates a streamflow-gaging station on the Niobrara River downstream from Spencer Dam, 5 mi southeast of Spencer, Nebr., and approximately $5 \mathrm{mi}$ upstream from the Eagle Creek confluence. Temporary gages were used in the area exclusively to record river stage as early as 1908 . Stage was related to daily discharge by computing the flow through the dam power house and spillgates. From October 1944 to November 1954, a water-stage recorder was in place 275 feet downstream from the dam. From November 1954 to September of 1957 a water-stage recorder was located $0.3 \mathrm{mi}$ 


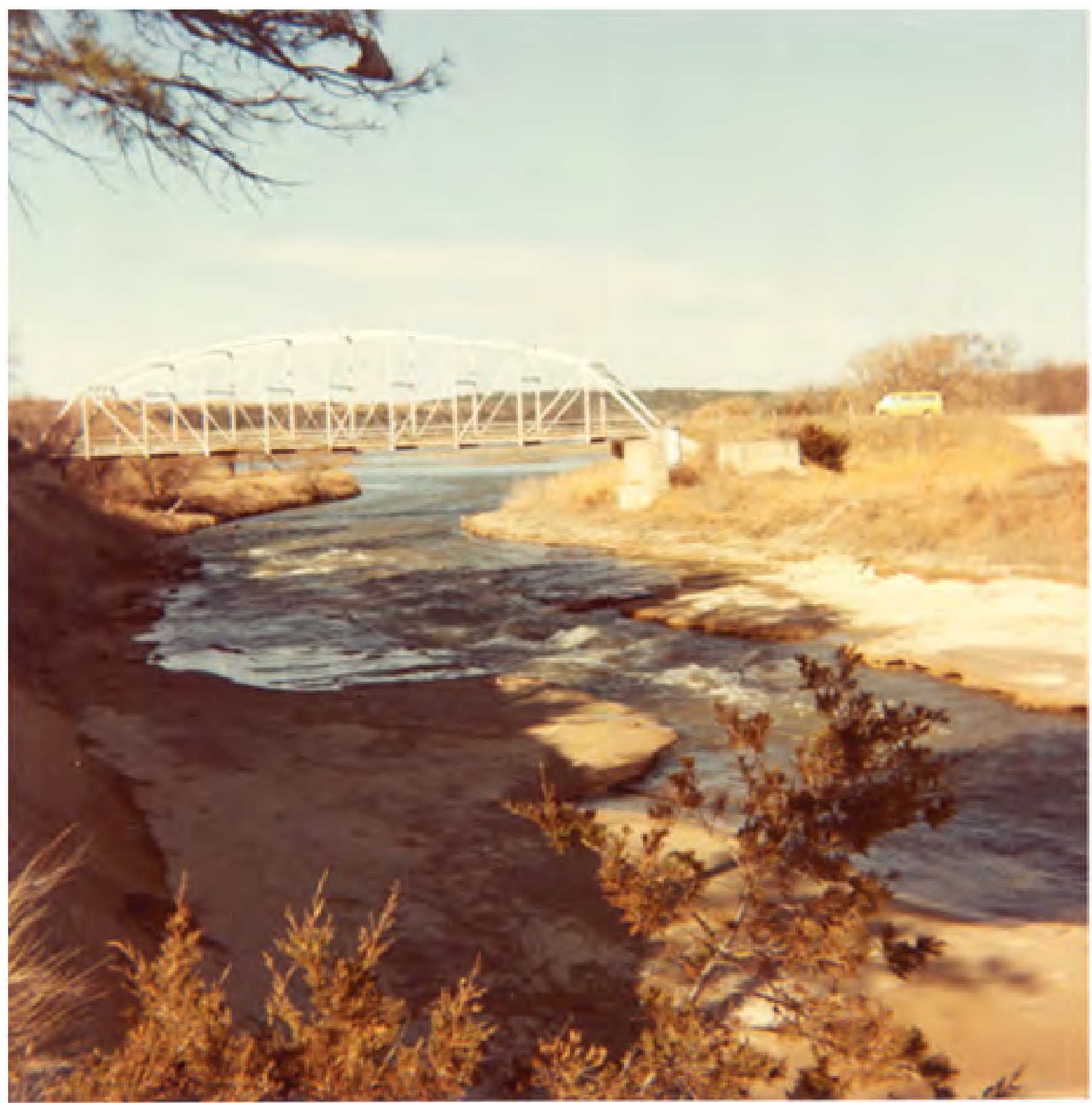

Figure 1-4. Photograph of the Niobrara River near Norden streamflow-gaging station reach. Photo was taken looking upstream from the right river bank. The gage house can be seen on the left river bank (right side of photo), just downstream from the bridge. Discharge measurements were made by both wading and using the bridge. However, only bridge measurements were used for the hydraulic geometry relation. The bedrock notch is now located several meters upstream from the bridge. (USGS file photograph) 
downstream. The most recent streamflow gage during the study period was established in August of 1963, and was in operation until October 2002. Most measurements were made from a cableway located downstream from the dam. A bridge is located approximately $0.25 \mathrm{mi}$ downstream from the dam. The left tower of the cableway was located $460 \mathrm{ft}$ downstream from the bridge, and its right tower was located $375 \mathrm{ft}$ downstream from the bridge. During some lower flows, wading measurements could be made downstream from the bridge in the vicinity of the cableway. The reach downstream from the dam has a single thalweg flowing between shifting sandbars. The gage was reinstated in April 2008.

\section{Niobrara River near Verdel}

The USGS operates a gage located approximately 7.5 mi upstream from the Verdigre Creek confluence on the downstream side of a county road bridge. The gage was established in April 1938 at an old county road bridge 2,600 $\mathrm{ft}$ downstream from the current bridge. In June 1939 the gage was moved $250 \mathrm{ft}$ downstream to an old bridge abutment on the right bank. No records were collected between May 1940 and June 1958. From June 1958 until July 1985 the gage was located near the old county road bridge; it was then moved to the new bridge, where it currently is located. The channel at the current location is approximately 3 times wider than the section used before 1986. The channel is wide and has several thalwegs in the vicinity of the current streamflow gage. Both banks are approximately $4 \mathrm{ft}$ high and are heavily vegetated. Most measurements are made from the bridge, but lower flows can be measured by wading in the vicinity of the bridge.

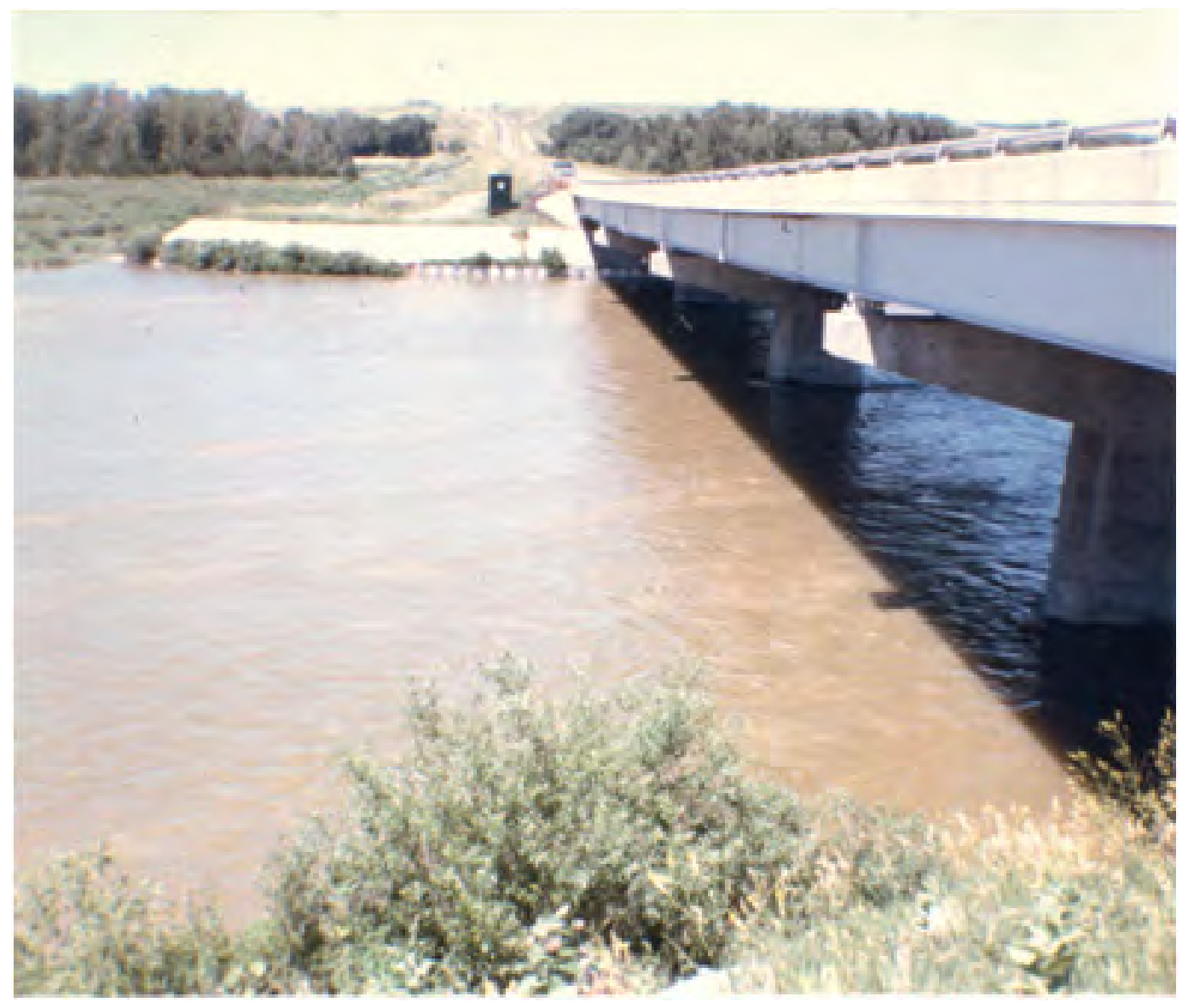

Figure 1-5. Photograph of the Niobrara River near Mariaville streamflow-gaging station reach. Photo was taken from the left river bank looking toward the right river bank. Gage house can be seen on opposite side of river. Flow is from right to left. Discharge measurements were made by both wading and using the bridge. However, only bridge measurements were used for the hydraulic geometry relation. (Photograph taken by Mark Nelson, Nebraska Department of Natural Resources) 


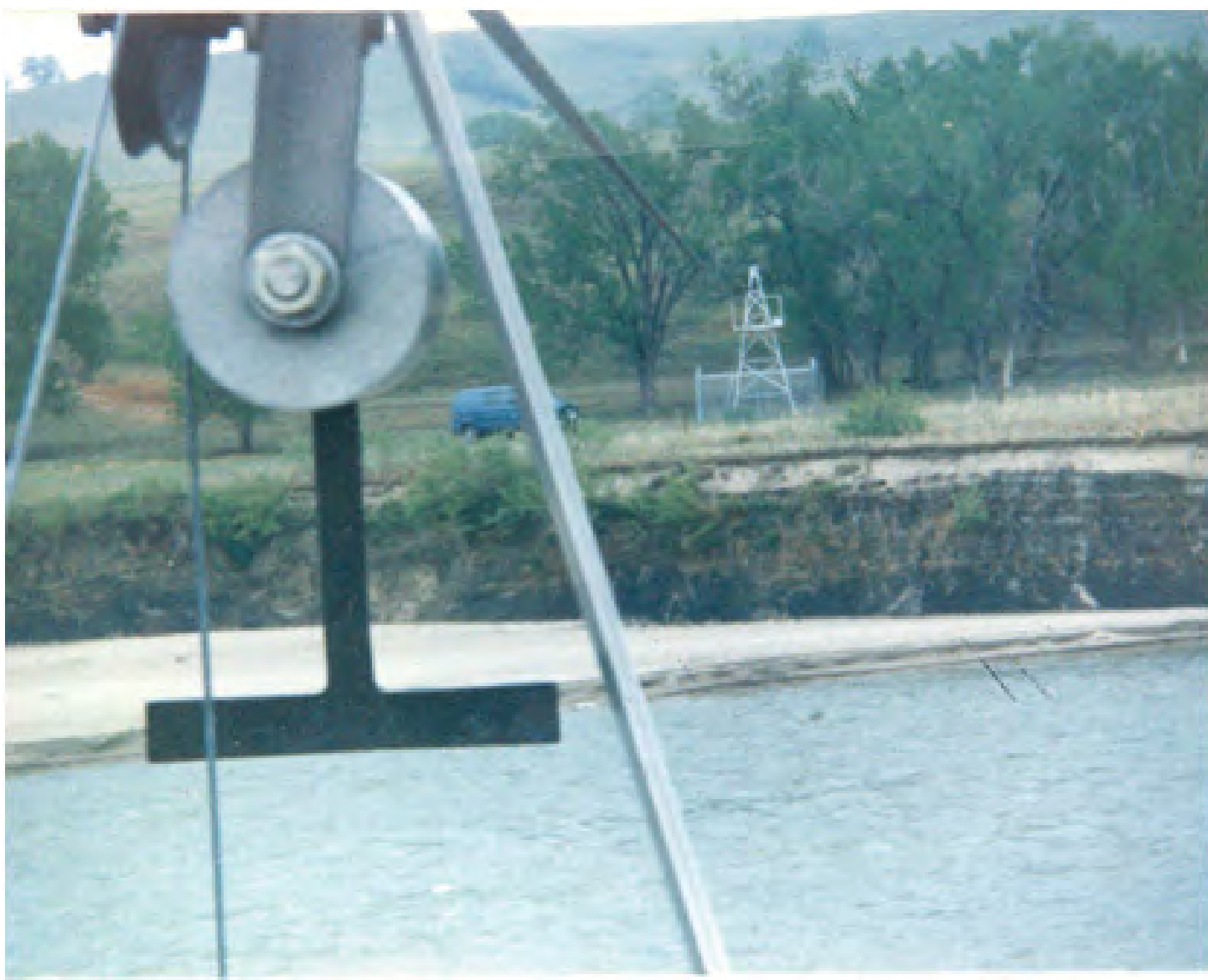

Figure 1-6. Photograph of the Niobrara River near Spencer streamflow-gaging station reach. Photo was taken from the right river bank looking toward the left river bank. Flow is from left to right. Only cable-car measurements were used for the hydraulic geometry relation. (USGS file photograph) 


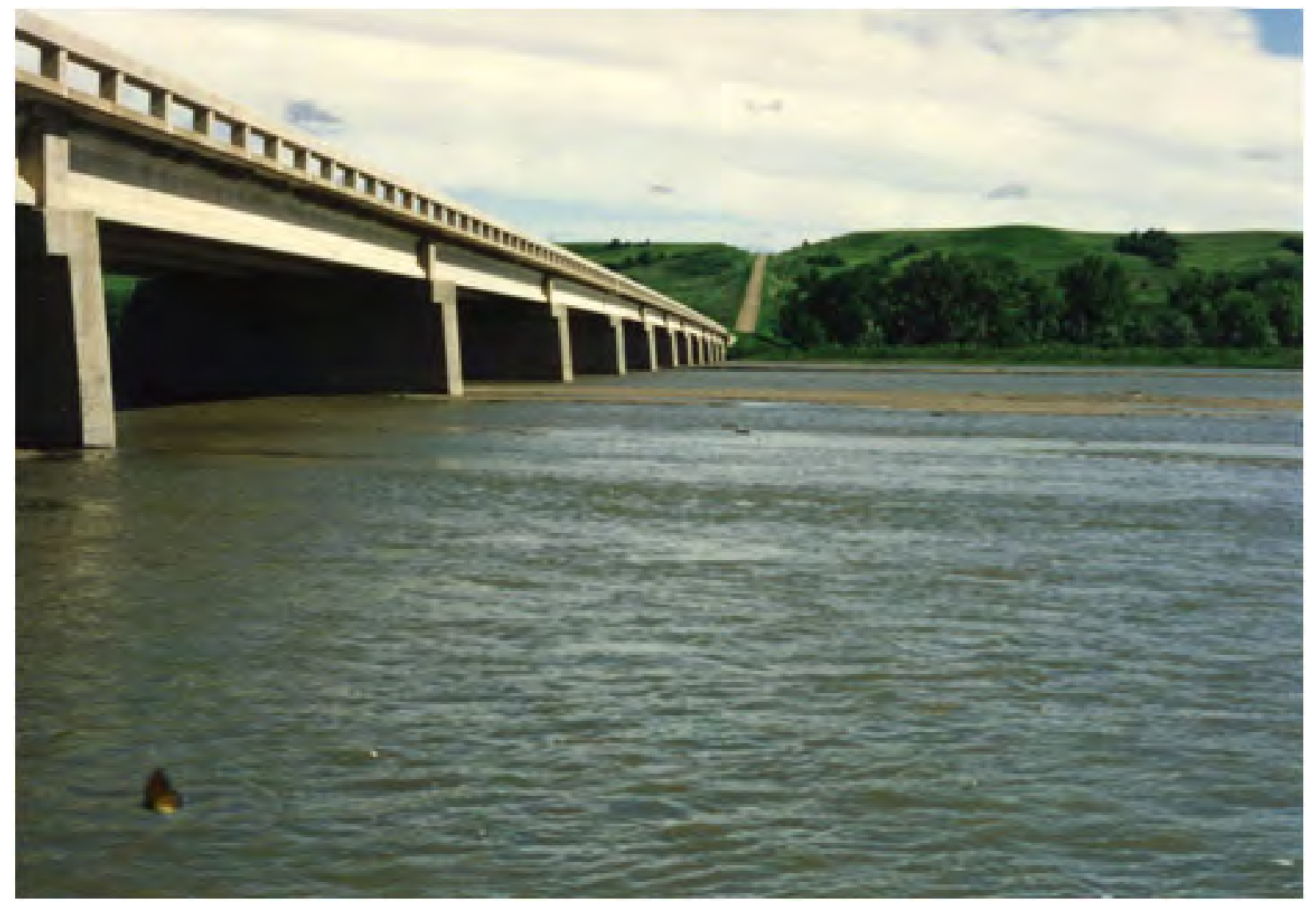

Figure 1-7. Photograph of the Niobrara River near Verdel streamflow-gaging station reach. Photo was taken from the right river bank looking toward the left river bank. Flow is from left to right. Only bridge measurements were used for the hydraulic geometry relation. The gage was moved to this location in 1986. Prior to 1986, the gage was located approximately one-half mile downstream at a narrower channel section. (USGS file photograph) 


\section{Appendix 2: Scatter Plots of At-A- Station Hydraulic-Geometry Relations}

\section{Appendix 2 Summary}

This appendix includes the scatter plots used to generate the at-a-station hydraulic-geometry models for each streamflow-gaging station. The ordinary least-squares regression lines shown on each plot correspond to the individual fitting lines shown in figure 9 of this report. The regression lines and data are shown with 90-percent confidence bounds. The coefficients of the models (equations 1 to 3 in Background section of this report), coefficients of determination for each least-squares regression line, and probability values for slope significance are shown in table 12 of this report.
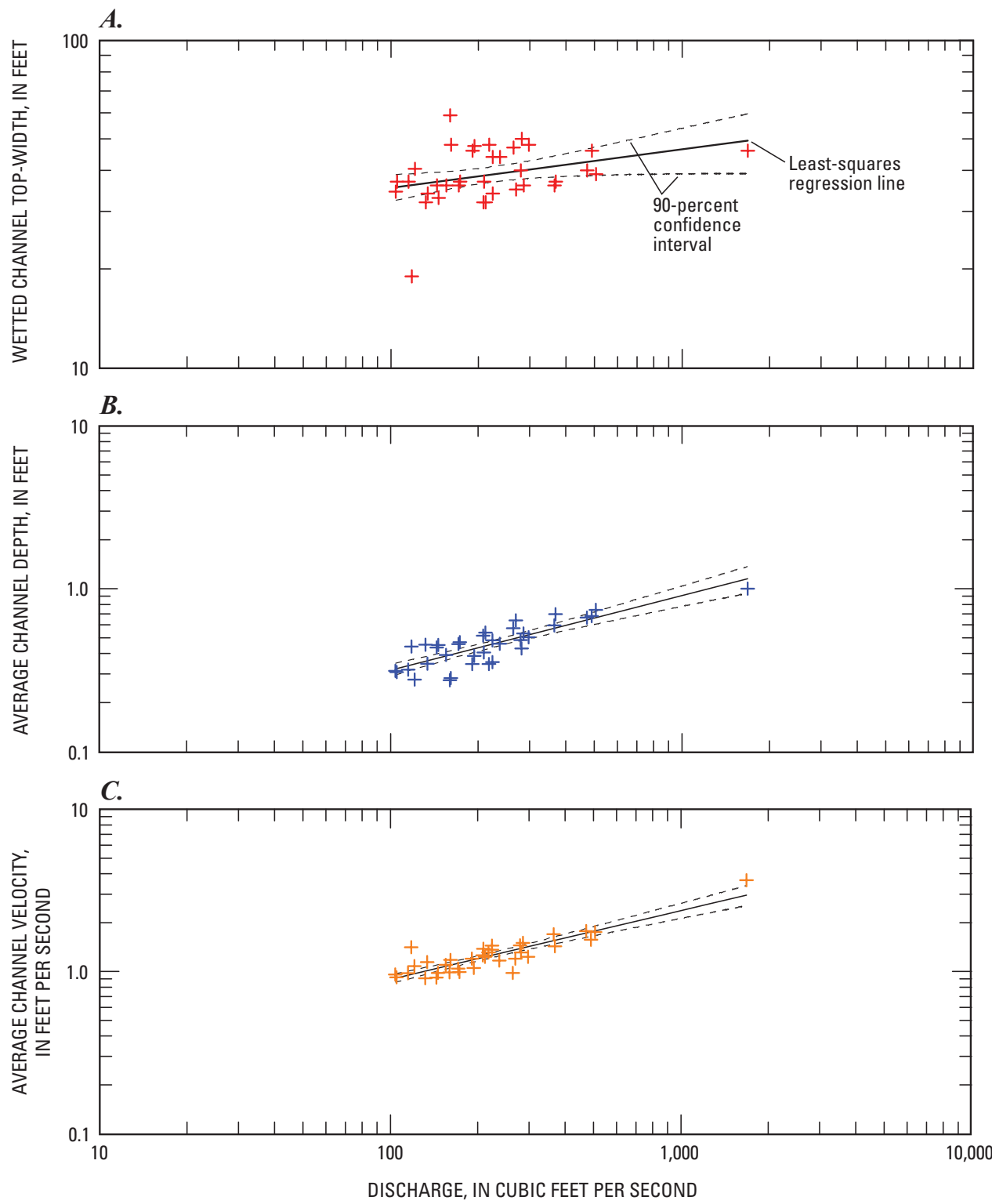

Figure 2-1. Scatter plots of the at-a-station hydraulic geometry relations for the USGS streamflow-gaging station on the Niobrara River near Hay Springs, Nebraska (06456500). (A) Relations between discharge and wetted channel-top width; (B) relations between discharge and average channel depth; $(C)$ relations from discharge and average channel velocity. The relations are shown for the period of record from water years 1951 to 1963, excluding water years 1956 to 1960 . The solid line through the data points is the ordinary leastsquares regression fit. The dashed lines running nearly parallel to the regression line are the 90-percent confidence bounds of the regression model. 


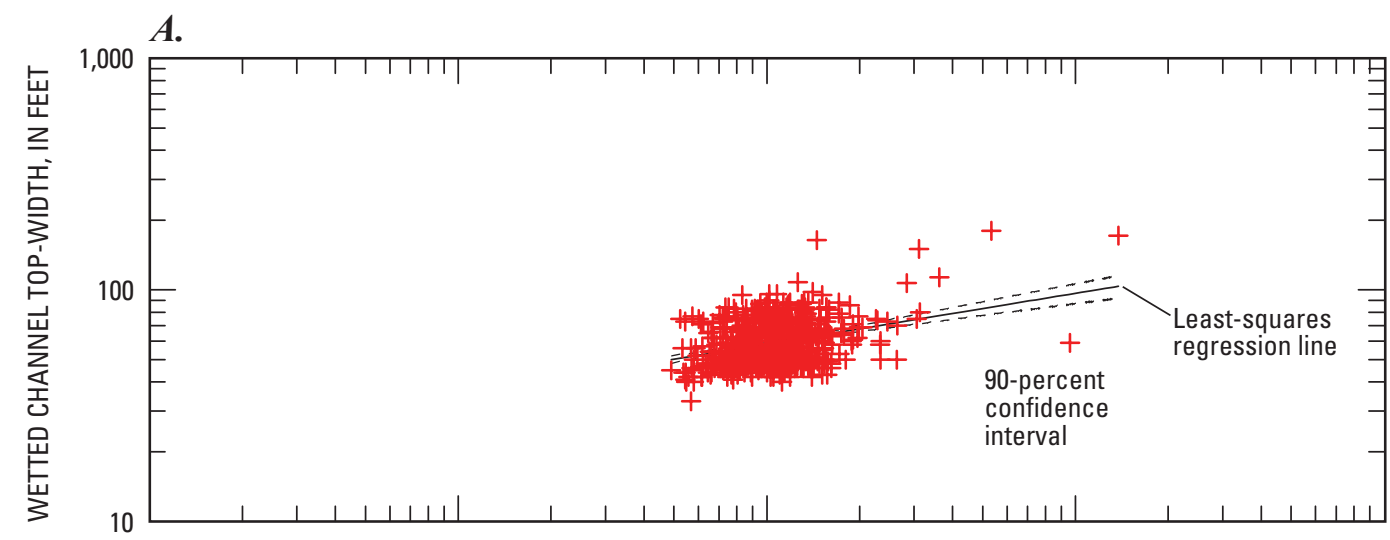

B.
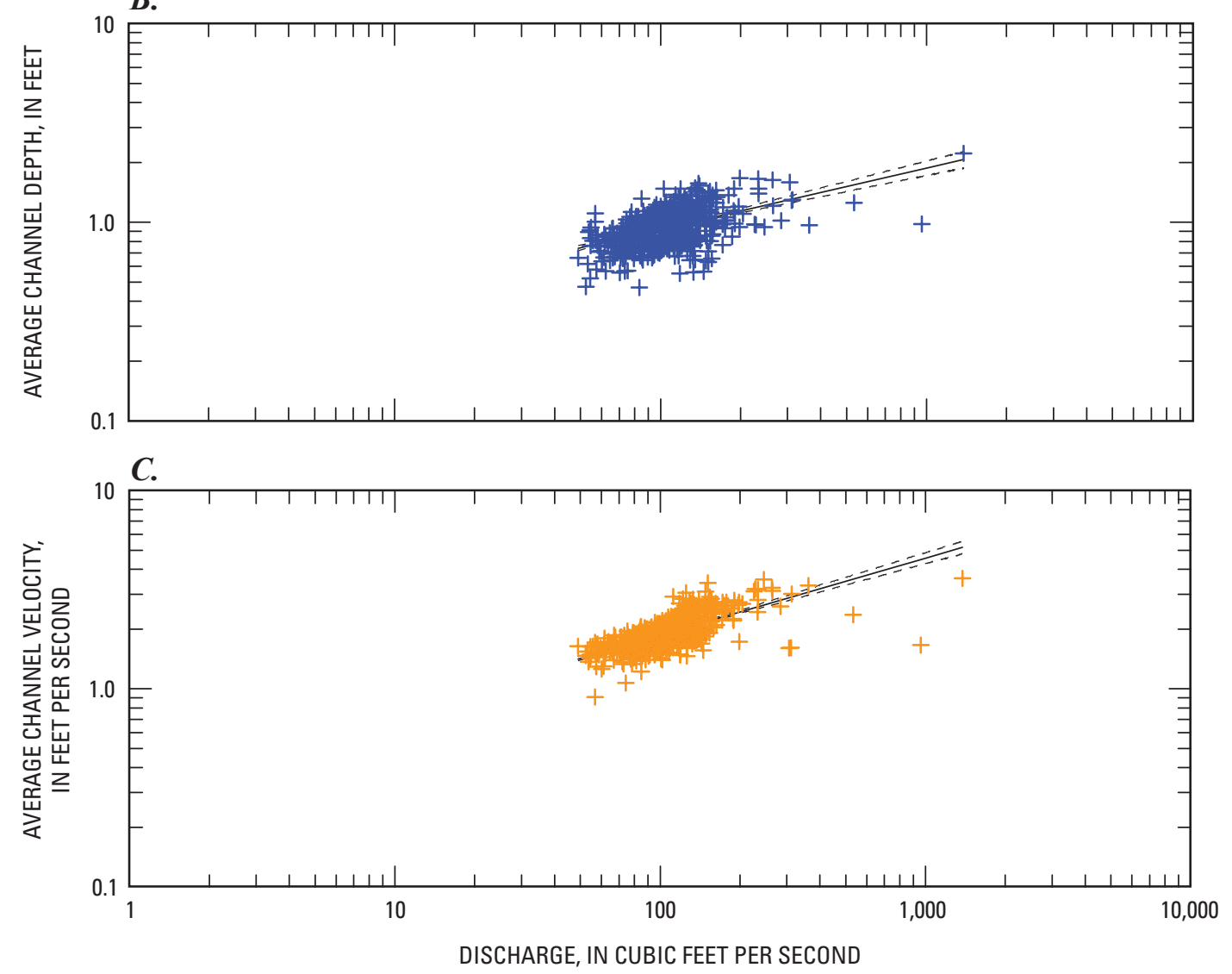

Figure 2-2. Scatter plots of the at-a-station hydraulic geometry relations for the USGS streamflowgaging station on the Niobrara River near Gordon, Nebraska (06457500). (A) Relations between discharge and wetted channel-top width; $(B)$ relations between discharge and average channel depth; $(C)$ relations between discharge and average channel velocity. The relations are shown for the period of record from water years 1964 to 1990 . The solid line through the data points is the ordinary least-squares regression fit. The dashed lines running nearly parallel to the regression line are the 90 -percent confidence bounds of the regression model. 


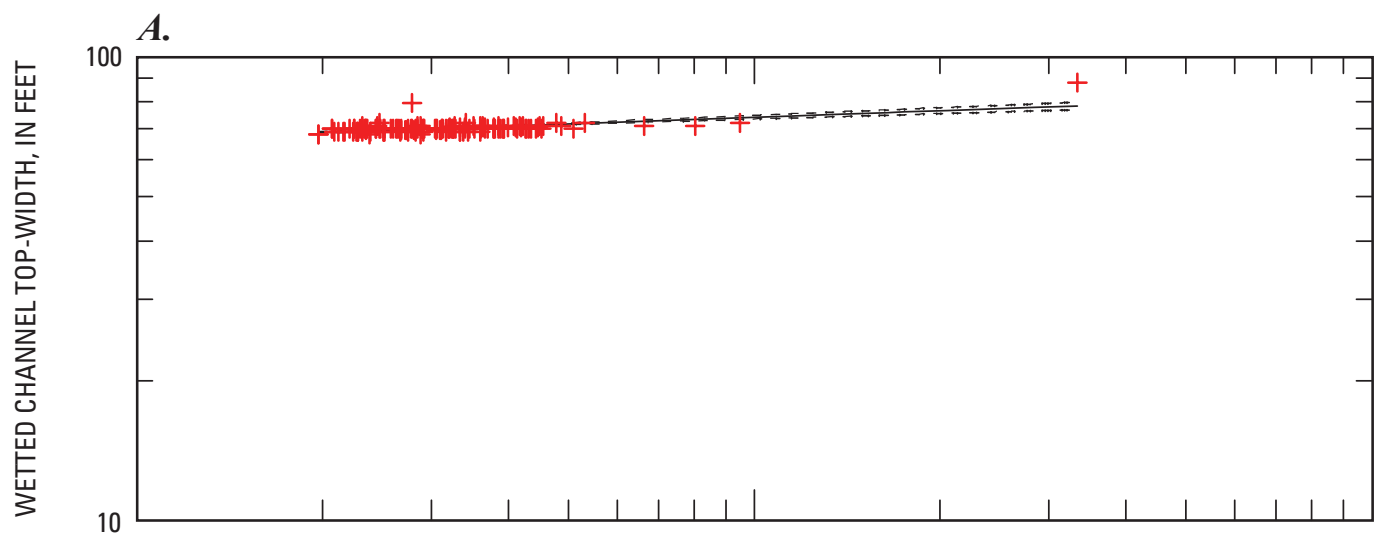

B.

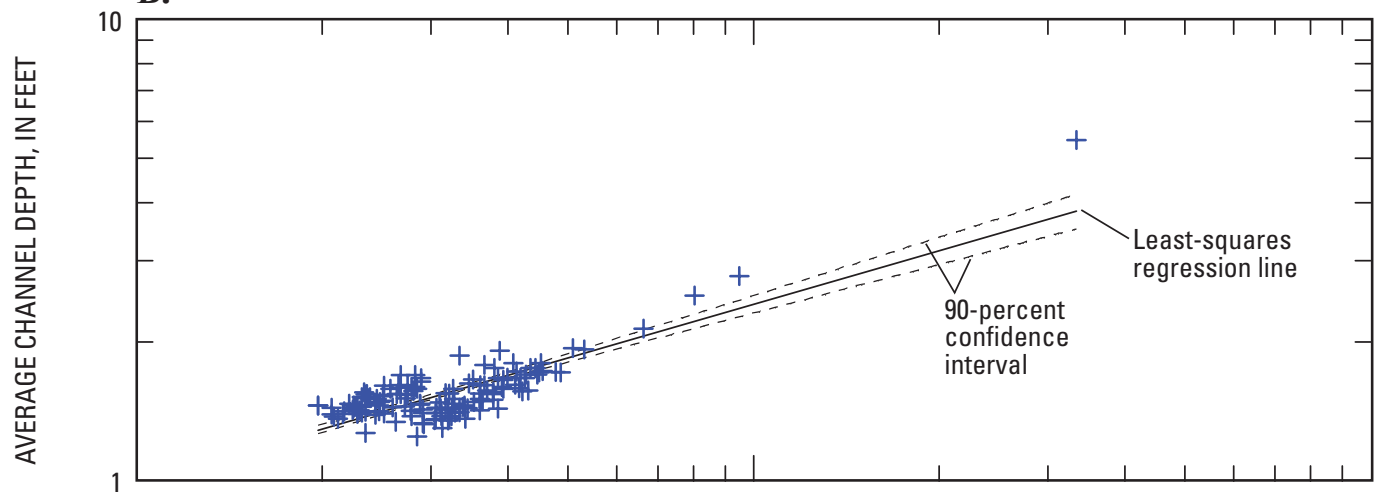

C.

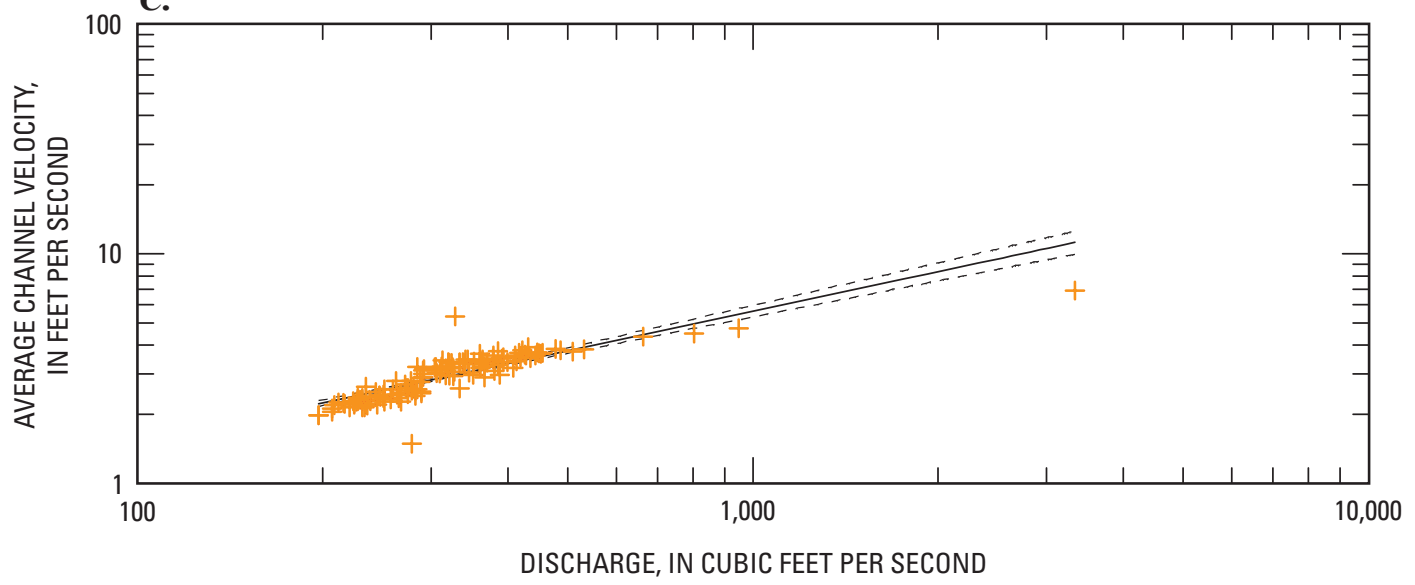

Figure 2-3. Scatter plots of the at-a-station hydraulic geometry relations for the USGS streamflow-gaging station on the Niobrara River near Cody, Nebraska (06459000). (A) Relations between discharge and wetted channel-top width; $(B)$ relations between discharge and average channel depth; $(C)$ relations between discharge and average channel velocity. The relations are shown for the period of record from water years 1949 to 1956 . The solid line through the data points is the ordinary least-squares regression fit. The dashed lines running nearly parallel to the regression line are the 90 -percent confidence bounds of the regression model. 

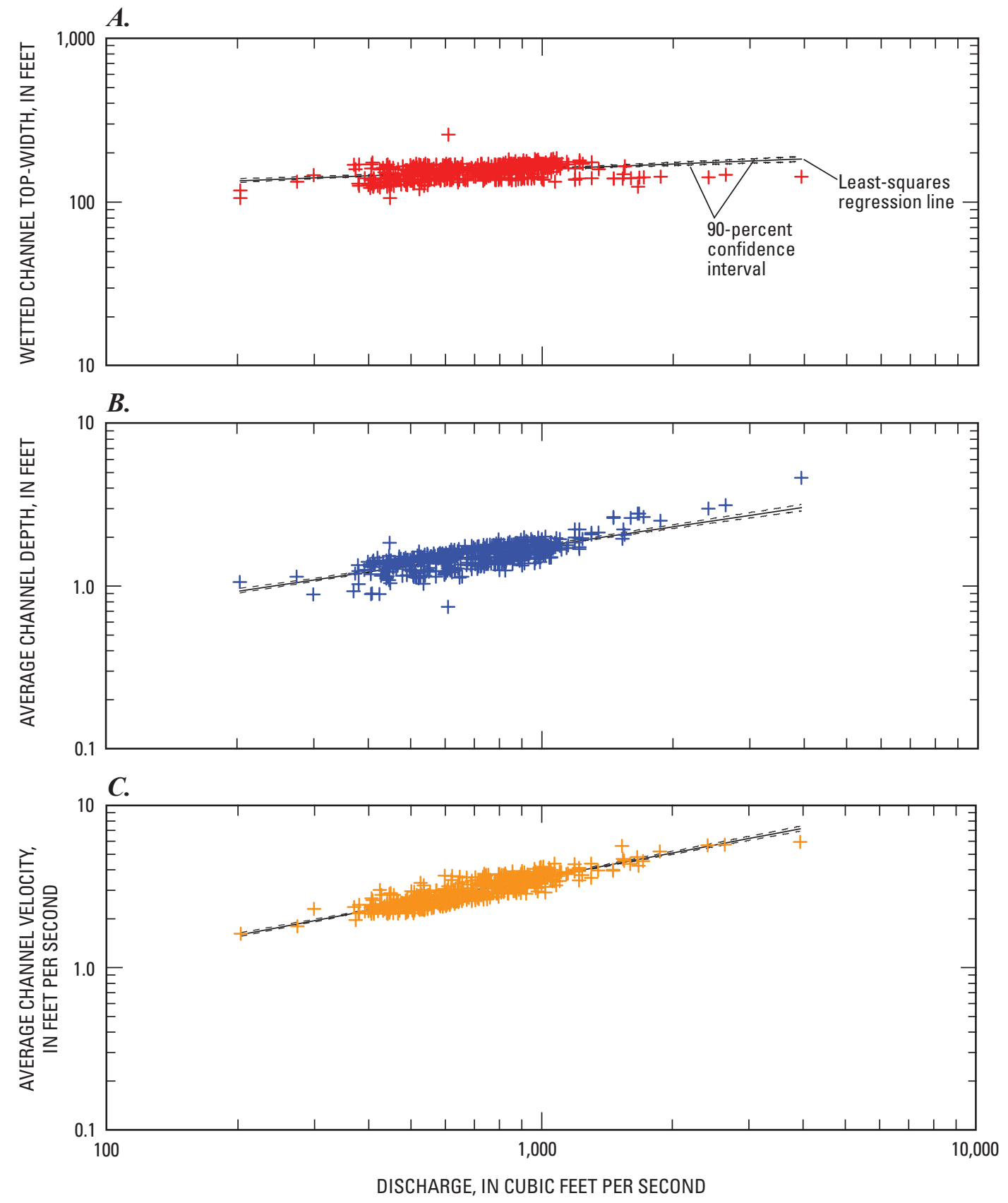

Figure 2-4. Scatter plots of the at-a-station hydraulic geometry relations for the USGS streamflowgaging station on the Niobrara River near Sparks, Nebraska (06461500). (A) Relations between discharge and wetted channel-top width; $(B)$ relations between discharge and average channel depth; $(C)$ relations between discharge and average channel velocity. The relations are shown for the period of record from water years 1964 to 2007. The solid line through the data points is the ordinary least-squares regression fit. The dashed lines running nearly parallel to the regression line are the 90-percent confidence bounds of the regression model. 
A.

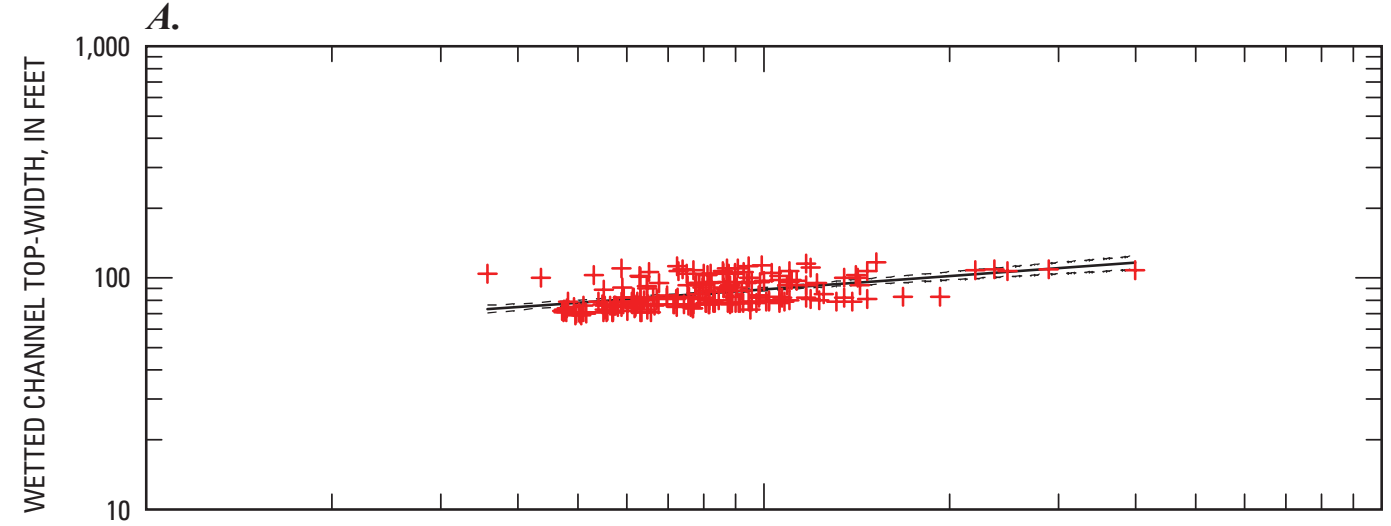

B.
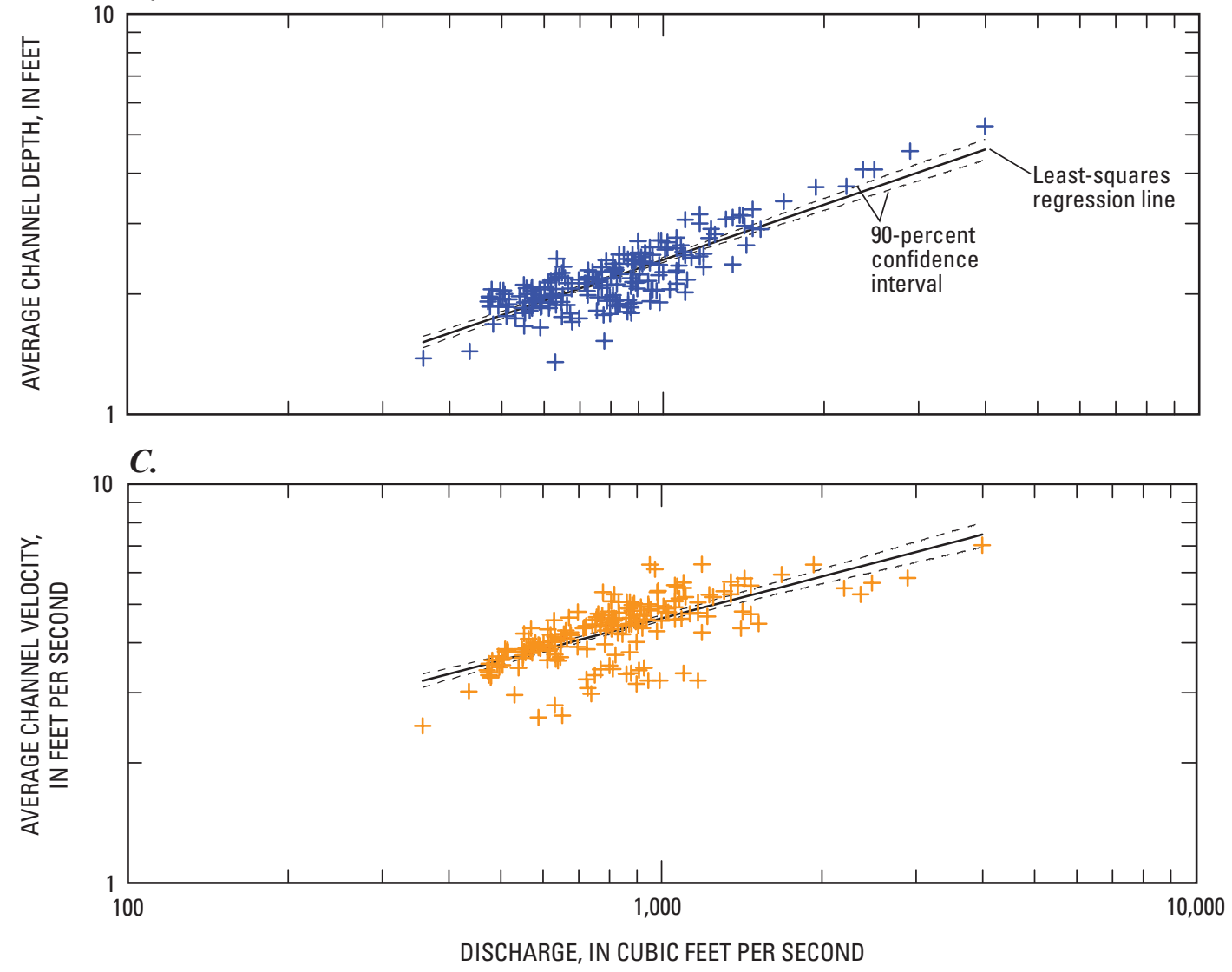

Figure 2-5. Scatter plots of the at-a-station hydraulic geometry relations for the USGS streamflowgaging station on the Niobrara River near Norden, Nebraska (06462000). (A) Relations between discharge and wetted channel-top width; $(B)$ relations between discharge and average channel depth; $(C)$ relations between discharge and average channel velocity. The relations are shown for the period of record from water years 1964 to 1983 . The solid line through the data points is the ordinary least-squares regression fit. The dashed lines running nearly parallel to the regression line are the 90-percent confidence bounds of the regression model. 

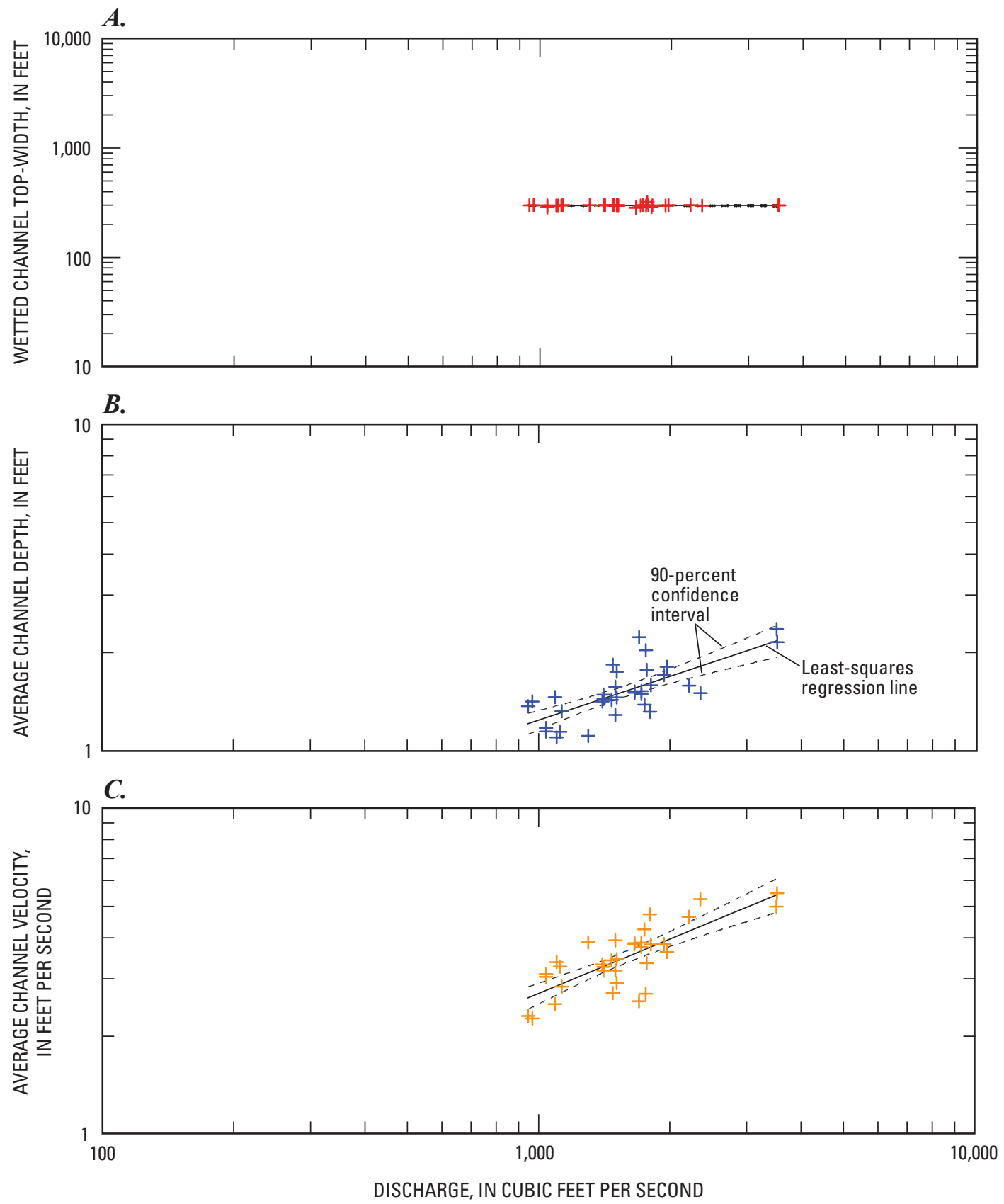

Figure 2-6. Scatter plots of the at-a-station hydraulic geometry relations for the USGS streamflow-gaging station on the Niobrara River near Mariaville, Nebraska (06463720). (A) Relations between discharge and wetted channel-top width; $(B)$ relations between discharge and average channel depth; $(C)$ relations from discharge and average channel velocity. The relations are shown for the period of record from water years 1986 to 1990. The solid line through the data points is the ordinary least-squares regression fit. The dashed lines running nearly parallel to the regression line are the 90-percent confidence bounds of the regression model. 
$A$.

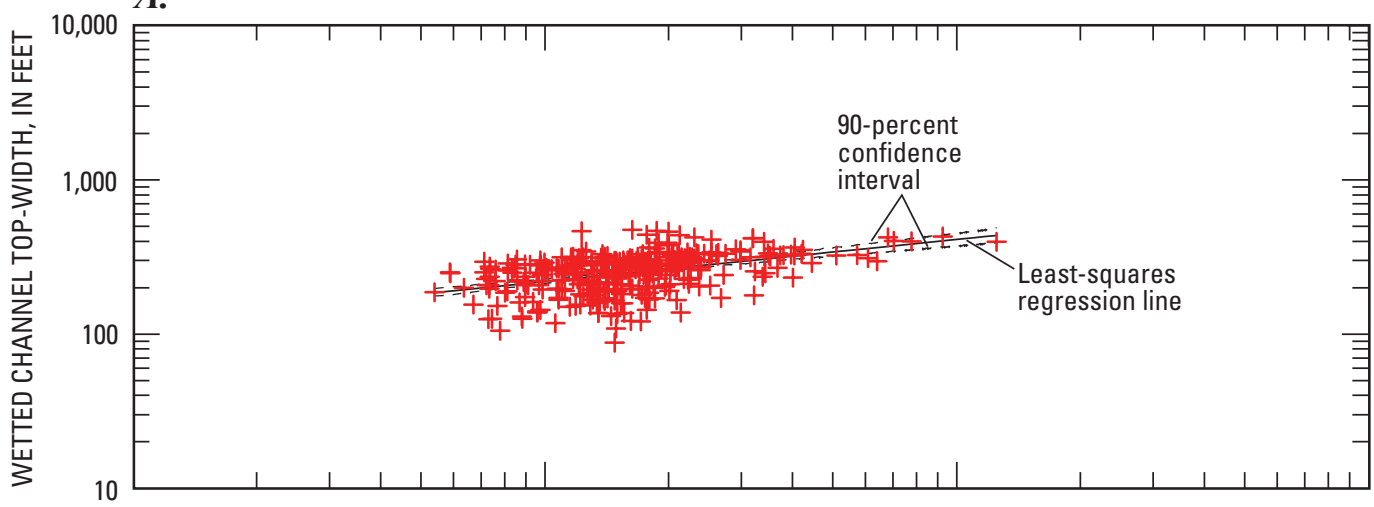

B.

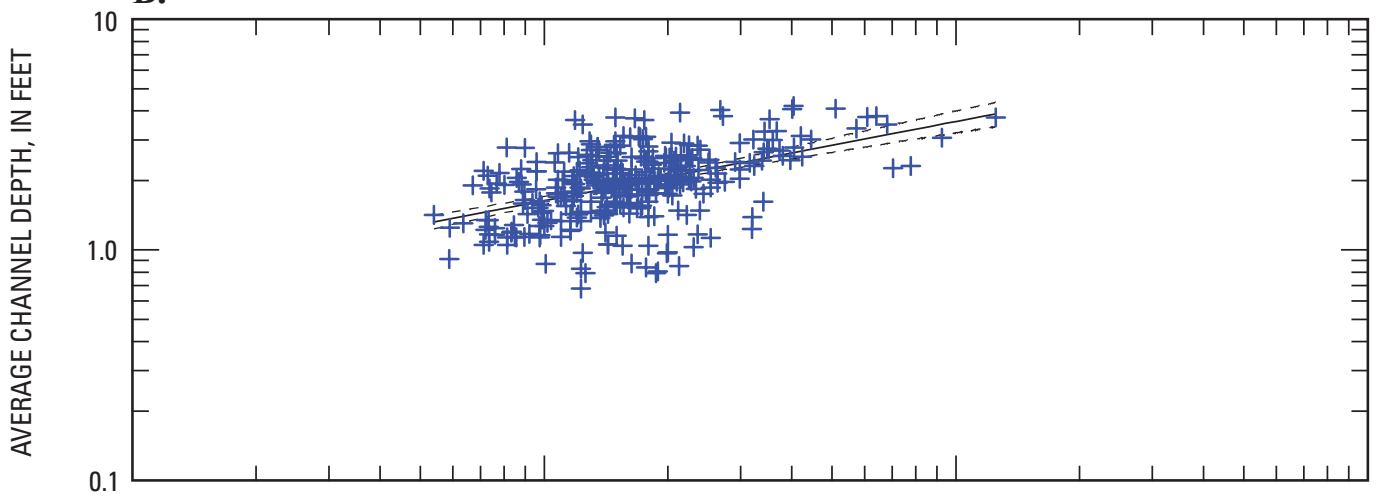

C.

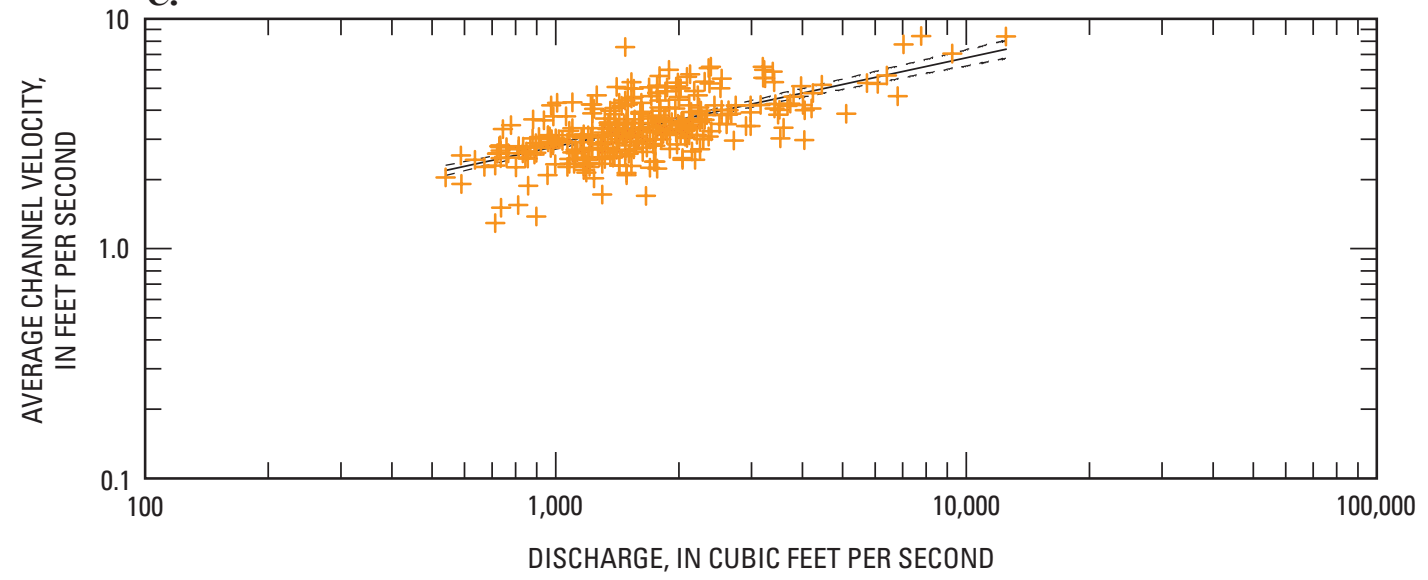

Figure 2-7. Scatter plots of the at-a-station hydraulic geometry relations for the USGS streamflow-gaging station on the Niobrara River near Spencer, Nebraska (06465000). (A) Relations between discharge and wetted channel-top width; $(B)$ relations between discharge and average channel depth; $(C)$ relations from discharge and average channel velocity. The relations are shown for the period of record from water years 1964 to 2002. The solid line through the data points is the ordinary least-squares regression fit. The dashed lines running nearly parallel to the regression line are the 90 -percent confidence bounds of the regression model. 


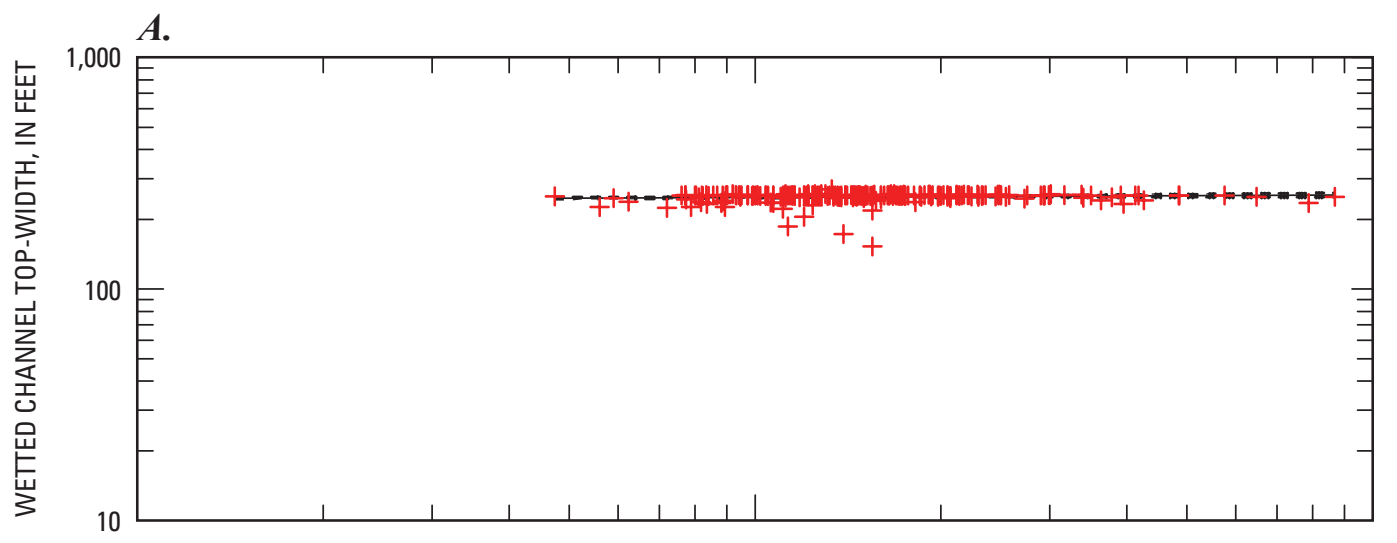

B.

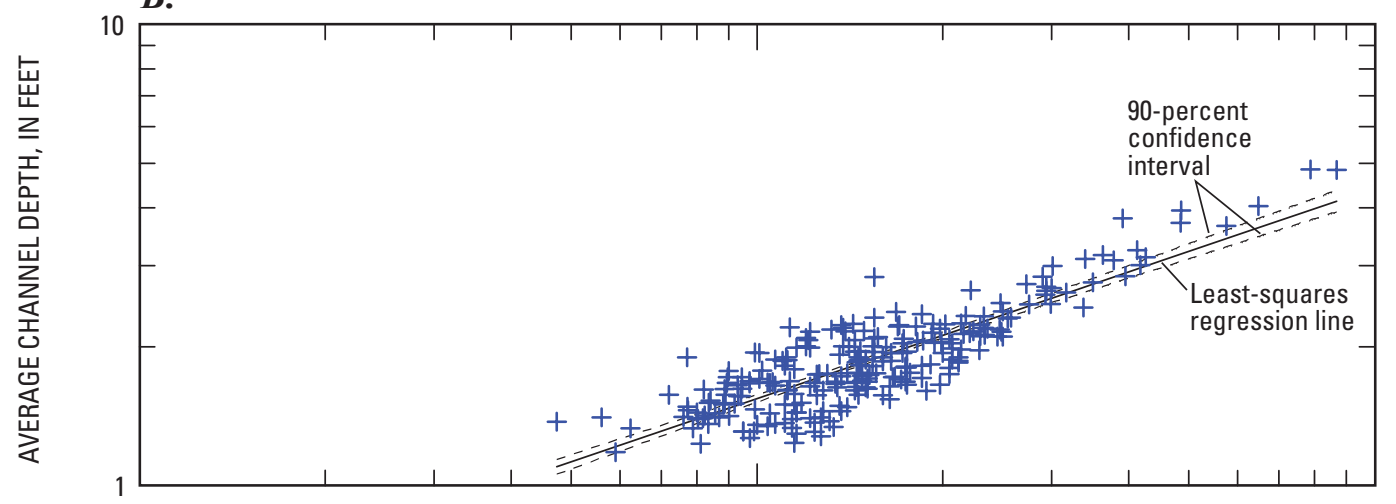

C.

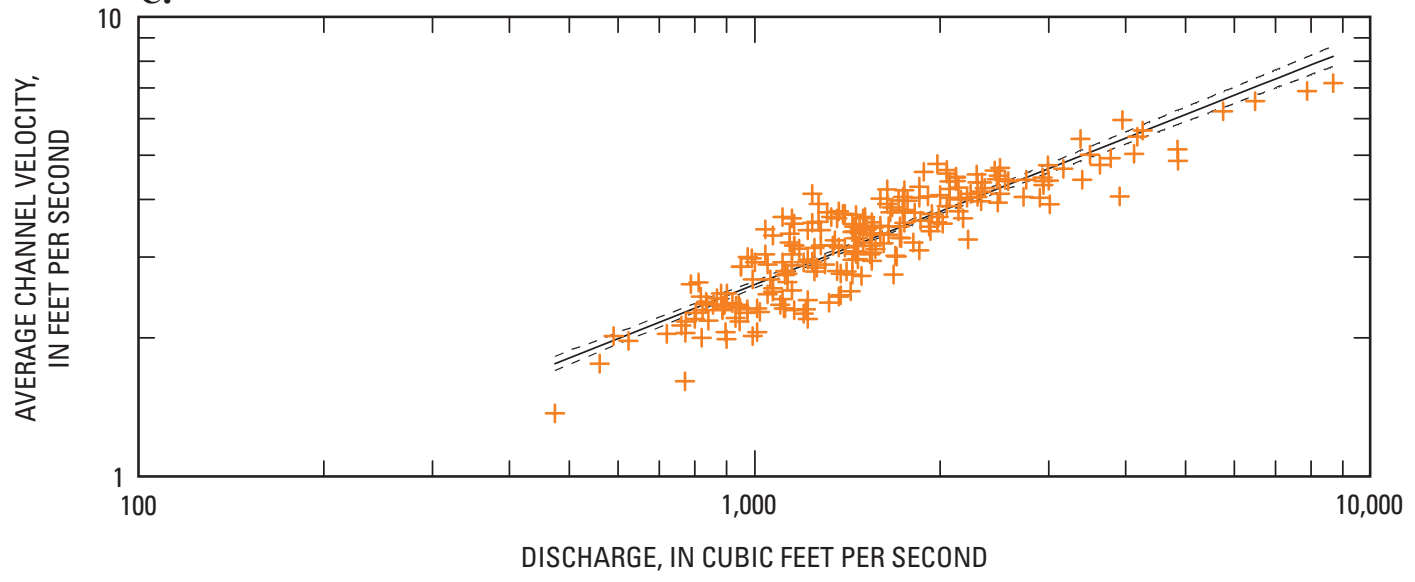

Figure 2-8. Scatter plots of the at-a-station hydraulic geometry relations for the USGS streamflow-gaging station on the Niobrara River near Verdel, Nebraska (06465500). (A) Relations between discharge and wetted channel-top width; $(B)$ relations between discharge and average channel depth; $(C)$ relations from discharge and average channel velocity. The relations are shown for the period of record from water years 1964 to 1985 . The gage moved upstream approximately one-half mile after water year 1985 (see figure 2-9 for post-1985 relations). The solid line through the data points is the ordinary least-squares regression fit. The dashed lines running nearly parallel to the regression line are the 90 -percent confidence bounds of the regression model. 

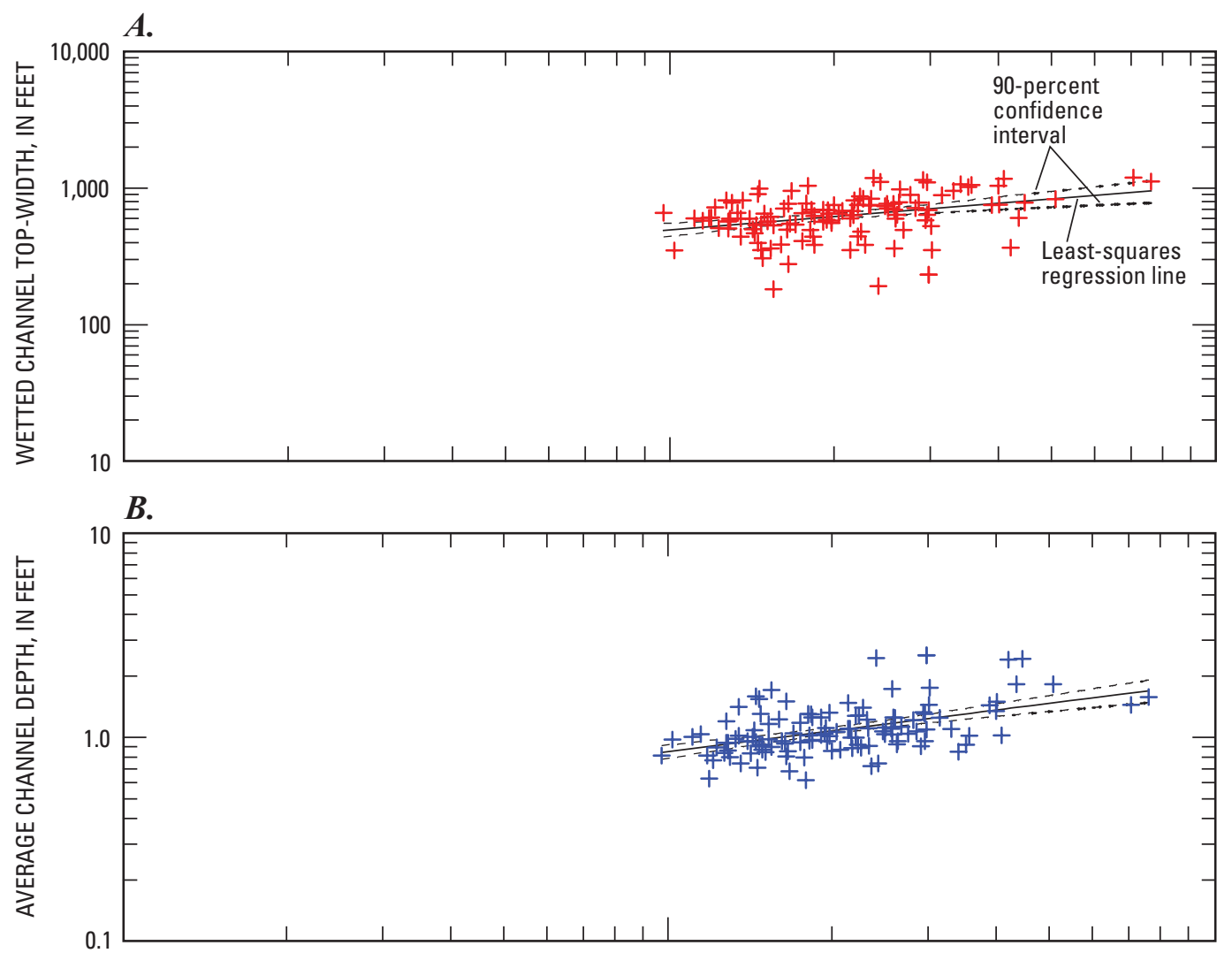

C.

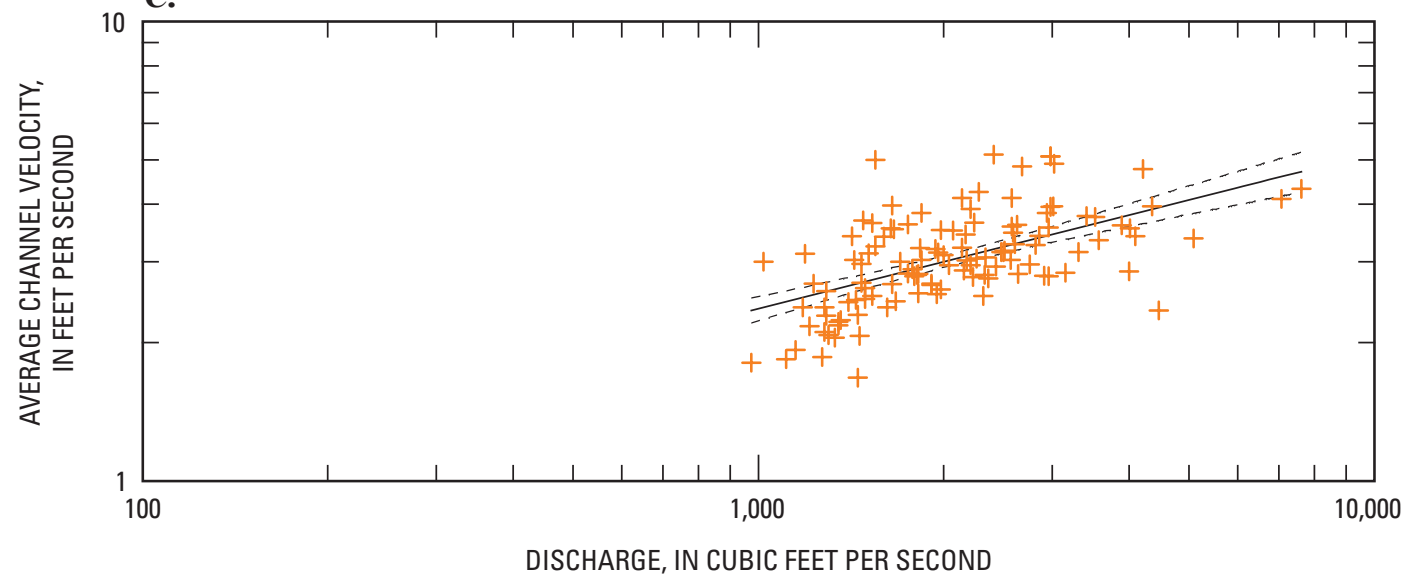

Figure 2-9. Scatter plots of the at-a-station hydraulic geometry relations for the USGS streamflowgaging station on the Niobrara River near Verdel, Nebraska (06465500). (A) Relations between discharge and wetted channel-top width; $(B)$ relations between discharge and average channel depth; $(C)$ relations from discharge and average channel velocity. The relations are shown for the period of record from water years 1986 to 2007. The gage moved upstream approximately one-half mile after water year 1985 (see figure 2-8 for pre-1986 relations). The solid line through the data points is the ordinary leastsquares regression fit. The dashed lines running nearly parallel to the regression line are the 90 -percent confidence bounds of the regression model. 
Publishing support provided by:

Rolla Publishing Service Center

For more information concerning this publication, contact:

Director, USGS Nebraska Water Science Center

5231 South 19th Street

Lincoln, NE 68512

(402) 328-4100

Or visit the Nebraska Water Science Center Web site at: http://ne.water.usgs.gov 
Back cover. Upper left photograph is the Niobrara River near Cody streamflow-gaging station reach and was taken looking upstream. Upper right photograph is the Niobrara River near Norden streamflow-gaging station reach and was taken looking upstream from the right river bank. Bottom photograph is the Niobrara River near Verdel streamflow-gaging station reach and was taken from the right river bank looking toward the left river bank. (USGS file photographs) 

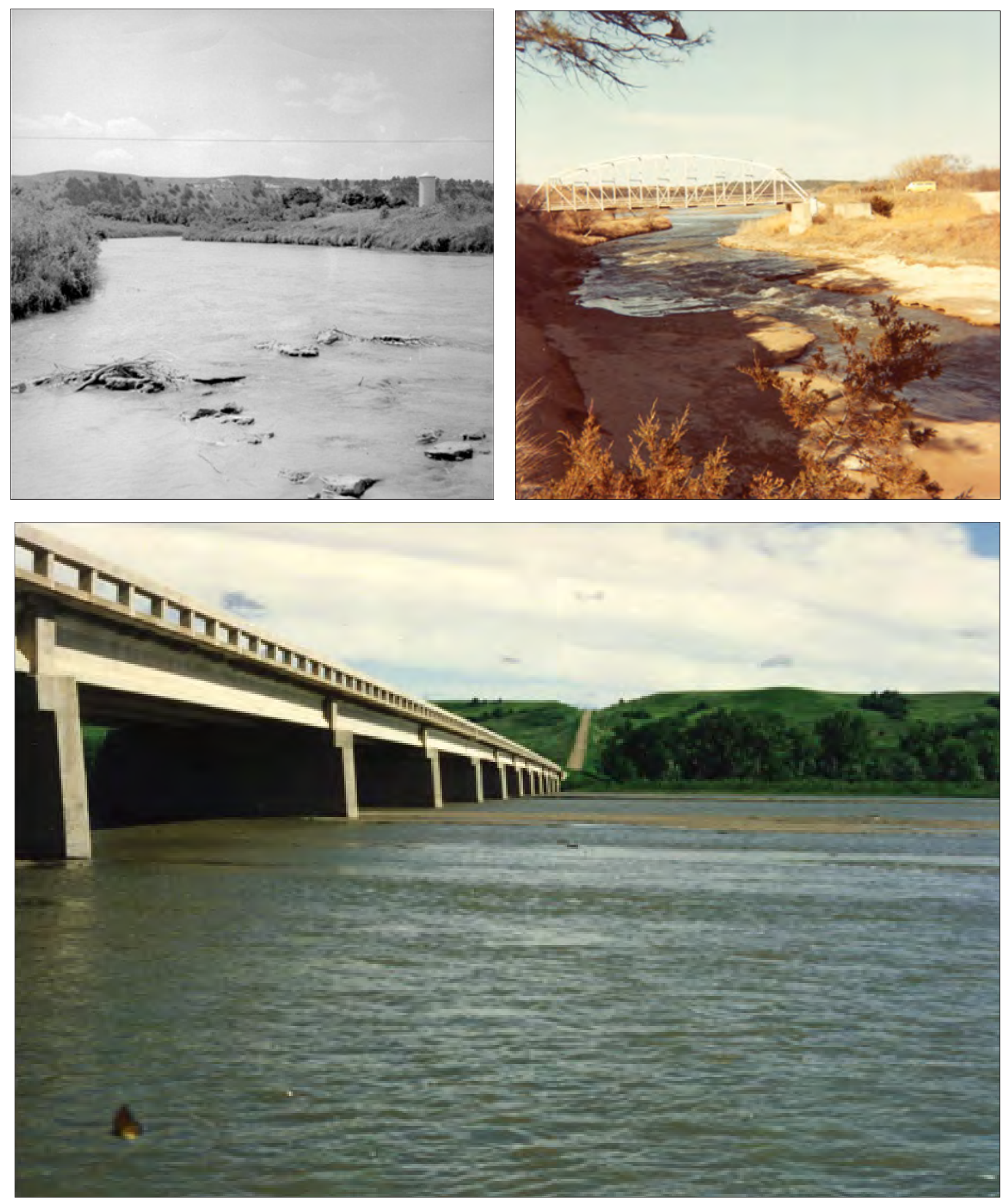

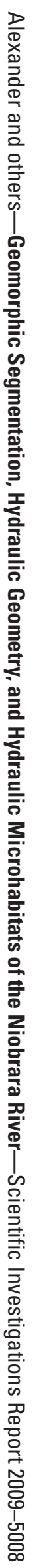

